\title{
MELT RATE TESTING FOR THE DWPF: Summary of FY02 Testing
}

\author{
T.H. Lorier \\ T.M. Jones \\ D.C. Witt
}

Westinghouse Savannah River Company Savannah River Technology Center Aiken, SC

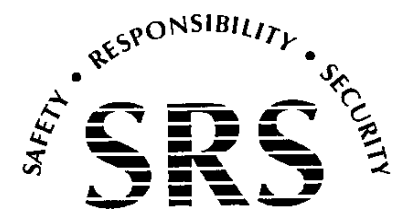


This document was prepared in conjunction with work accomplished under Contract No. DE-AC09-96SR18500 with the U. S. Department of Energy.

\section{DISCLAIMER}

This report was prepared as an account of work sponsored by an agency of the United States Government. Neither the United States Government nor any agency thereof, nor any of their employees, makes any warranty, express or implied, or assumes any legal liability or responsibility for the accuracy, completeness, or usefulness of any information, apparatus, product or process disclosed, or represents that its use would not infringe privately owned rights. Reference herein to any specific commercial product, process or service by trade name, trademark, manufacturer, or otherwise does not necessarily constitute or imply its endorsement, recommendation, or favoring by the United States Government or any agency thereof. The views and opinions of authors expressed herein do not necessarily state or reflect those of the United States Government or any agency thereof.

This report has been reproduced directly from the best available copy.

Available for sale to the public, in paper, from: U.S. Department of Commerce, National Technical Information Service, 5285 Port Royal Road, Springfield, VA 22161, phone: (800) 553-6847, fax: (703) 605-6900

email: orders@ntis.fedworld.gov

online ordering: http://www.ntis.gov/help/index.asp

Available electronically at http://www.osti.gov/bridge

Available for a processing fee to U.S. Department of Energy and its contractors, in paper, from: U.S. Department of Energy, Office of Scientific and Technical Information, P.O. Box 62, Oak Ridge, TN 37831-0062,

phone: (865)576-8401,

fax: (865)576-5728

email: $\underline{\text { reports@ adonis.osti.gov }}$ 


\title{
MELT RATE TESTING FOR THE DWPF: Summary of FY02 Testing
}

\author{
T.H. Lorier \\ T.M. Jones \\ D.C. Witt
}

Westinghouse Savannah River Company Savannah River Technology Center

Aiken, SC under that contract. 


\begin{tabular}{|c|c|c|c|}
\hline $\begin{array}{l}\text { Task Title: DWPF Melt Rate } \\
\text { Testing (Summary of FY02 } \\
\text { Testing) }\end{array}$ & & $\begin{array}{l}\text { TTR Number: } \\
\text { HLW/DWPF/TTR- } \\
\text { 02-0001, Rev. } 1\end{array}$ & $\begin{array}{l}\text { TTR Date: } \\
12 / 17 / 01\end{array}$ \\
\hline $\begin{array}{l}\text { Author: } \\
\text { T.H. Lorier }\end{array}$ & Signature & $\begin{array}{l}\text { Organization: } \\
\text { ITS }\end{array}$ & $\begin{array}{l}\text { Date: } \\
12 / 2 / 02\end{array}$ \\
\hline $\begin{array}{l}\text { Author: } \\
\text { T.M. Jones }\end{array}$ & Signatype: & $\begin{array}{l}\text { Organization: } \\
\text { ITS }\end{array}$ & Date: $/ 2 / 02$ \\
\hline $\begin{array}{l}\text { Author/Task Leader: } \\
\text { D.C. Witt }\end{array}$ & Signature: & $\begin{array}{l}\text { Organization: } \\
\text { ITS }\end{array}$ & Date: $3 / 02$ \\
\hline $\begin{array}{l}\text { Technical Reviewer: } \\
\text { M.E. Smith }\end{array}$ & Signature: & $\begin{array}{l}\text { Organization: } \\
\text { ITS }\end{array}$ & $\begin{array}{l}\text { Date: } \\
12 / 6 / 02\end{array}$ \\
\hline $\begin{array}{l}\text { Technical Reviewer: } \\
\text { D.K. Peeler }\end{array}$ & Sign fure: y ybala & $\begin{array}{l}\text { Organization: } \\
\text { ITS }\end{array}$ & $\begin{array}{l}\text { Date: } \\
12 / 2 / 02\end{array}$ \\
\hline $\begin{array}{l}\text { Level } 3 \text { Manager: } \\
\text { E.W. Holtzscheiter }\end{array}$ & Sianature: & $\begin{array}{l}\text { Organization: } \\
\text { ITS }\end{array}$ & Date: $12 / 02$ \\
\hline $\begin{array}{l}\text { Level } 4 \text { Manager: } \\
\text { S.L. Marra }\end{array}$ & Signgure: \&hanon flawa & $\begin{array}{l}\text { Organization: } \\
\text { ITS }\end{array}$ & $\begin{array}{l}\text { Date: } \\
2 / 6 / 02\end{array}$ \\
\hline
\end{tabular}


Immobilization Technology Section

Savannah River Technology Center

Westinghouse Savannah River Company

\section{GLOSSARY}

ACTL

Aiken County Technology Laboratory

DOE

Department of Energy

DTA

Differential Thermal Analysis

DWPF

Defense Waste Processing Facility

HLW

High Level Waste

ITS

Immobilization Technology Section

LLW

Low Level Waste

LMR

Linear Melt Rate

MRF

Melt Rate Furnace

PCCS

Product Composition Control System

SB

Sludge Batch

SMRF

Slurry-fed Melt Rate Furnace

SRAT

Sludge Receipt Adjustment Tank

SRTC

Savannah River Technology Center

STA

Simultaneous Thermal Analyzer

TFA

Tanks Focus Area

TG

Thermogravimetric

TIM

Task Integration Manager

$\mathrm{T}_{\mathrm{L}}$

Liquidus Temperature

WL

Waste Loading

$\Delta \mathrm{G}_{\mathrm{P}}$

Free energy of hydration 
Immobilization Technology Section

Savannah River Technology Center

Westinghouse Savannah River Company

This page intentionally left blank. 
Immobilization Technology Section

WSRC-TR-2002-00545

Savannah River Technology Center

Westinghouse Savannah River Company

\section{ACKNOWLEDGEMENTS}

The authors would like to acknowledge David Peeler, Michael Smith, and Michael Stone for their technical guidance and reviews; Dennis Bickford for his recommendations and assistance in the operation of the slurry-fed melt rate furnace; Frances Williams, Mary Moss, Tony Burckhalter, Vickie Williams, Sammie King, and Jon Duvall for their patience and hard work; Curtis Sexton and Gary Dobos for glass-shop work; and William Holtzscheiter (TFA TIM for Immobilization) and Sharon Marra for management and guidance. This study was co-funded by the Department of Energy's Office of Science and Technology through the Tanks Focus Area and through the Defense Waste Processing Facility. Westinghouse Savannah River Company is operated for the U.S. Department of Energy under Contract No. DE-AC0996SR18500. 
GLOSSARY $\mathbf{v}$

ACKNOWLEDGEMENTS. vii

LIST OF FIGURES.....................................................................

LIST OF TABLES..............................................................x

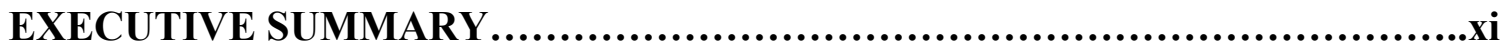

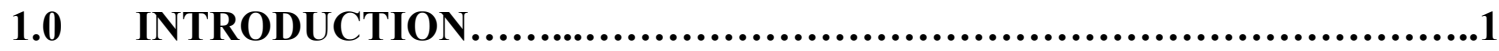

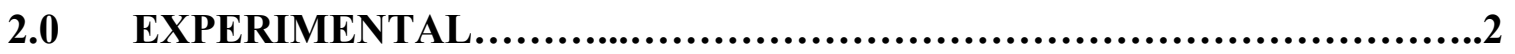

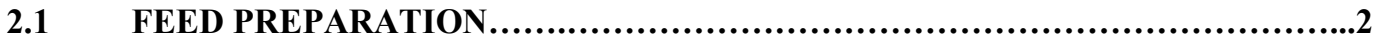

2.2 MELT RATE FURNACE (MRF) .................................................2

2.2.1 Equipment Description and Operation.......................................2

$2.3 \quad$ TOP-LOADING FURNACE TESTING...........................................

2.3.1 Equipment Description and Operation......................................

2.4 SLURRY-FED MELT RATE FURNACE TESTING..................................4

2.4.1 Equipment Description and Operation.......................................4

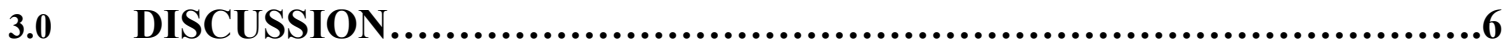

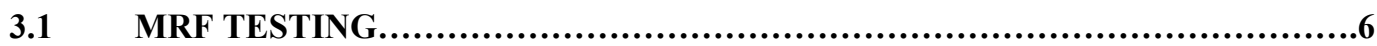

3.1.1 Baseline Tests............................................................6

3.1.2 Higher Waste Loading Tests................................................ 7

3.1.3 Batch Chemical Tests...........................................................10

3.1.4 Frit Particle-size Tests.........................................................11

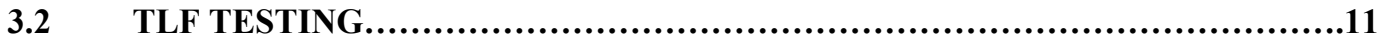

3.2.1 Baseline Tests..........................................................11

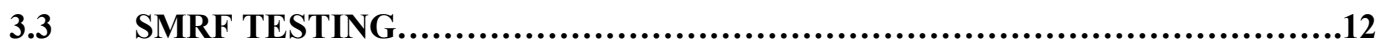

3.3.1 SMRF Tests.............................................................12

3.3.1.1 Frit 200/Purex Sludge Feed Characterization Runs.............................13

3.3.1.2 Initial Frit 200/SB2 Runs.......................................................13

3.3.1.2.1 Frit 200/SB2 Baseline Melt Rate Test - 7/15/02 .......................13

3.3.1.2.2 Frit 200/SB2 Baseline Melt Rate Test - 7/16/02 .......................14

3.3.1.3 Frit 320/SB2 Runs.................................................... 15

3.3.1.3.1 Frit 320/SB2 Baseline Melt Rate Test - 7/17/02 _....................15

3.3.1.3.2 Frit 320 SB2 Melt Rate Test with Bubbler - ..........................15 $7 / 18 / 02 \& 7 / 22 / 02$

3.3.1.3.3 Frit 320/SB2 Baseline Melt Rate Test - 7/30/02 ......................18

3.3.1.3.4 Frit 320/SB2 Melt Rate Test with Bubbler - 7/31/02 ..................18 
Savannah River Technology Center

Westinghouse Savannah River Company

3.3.1.4 Frit 200/SB2 Runs...................................................19

3.3.1.4.1 Frit 200/SB2 Baseline Melt Rate Test - 8/7/02 ........................20

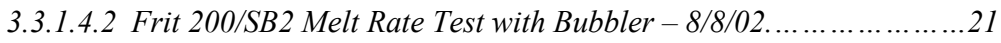

3.3.2 Melt Rate Comparison of Frit 320 and Frit 200 with SB2...................21

3.3.3 Mini Airlift Bubbler Performance with Frit 320 and Frit 200..............22

3.3.4 Frit 200/Frit 320 Cold Cap Comparisons...................................22

3.3.5 Melter Glass Pool Surface Layer.......................................23

3.4 COMPARISON OF MELT RATE EQUIPMENT ...................................23

THERMAL ANALYSIS.....................................................24

URANIUM STUDIES........................................................25

4.0 CONCLUSIONS/SUMMARY ...........................................26

5.0 FUTURE/ONGOING WORK...........................................27

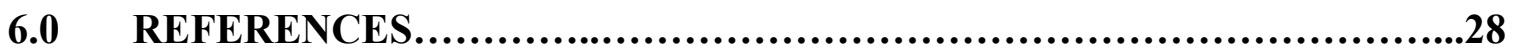

APPENDIX A

APPENDIX B

APPENDIX C 


\section{LIST OF FIGURES}

Figure 2-1

Figure 2-2

Figure 2-3

Figure 2-4

Figure 3-1

Figure 3-2

Figure 3-3

Figure 3-4

Figure 3-5

Figure 3-6

Figure 3-7

Figure 3-8

Figure 3-9

Figure 3-10

Figure 3-11

Figure 3-12

Figure 3-13

Figure 3-14

Figure 3-15

Figure 3-16

Figure 4-1
The Melt Rate Furnace............................................................. 3

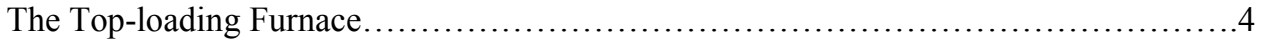

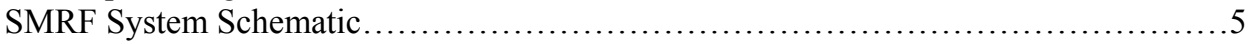

ACTL Slurry-fed Melt Rate Furnace................................................6

Plot of the Melt Rate Data for Frit 320 with SB2 as a Function of Waste Loading.........8 (Data from Table 3-2).

Plot of Waste Throughput for Frit 320 with SB2 as a Function of Waste Loading .......10 (Data from Table 3-3).

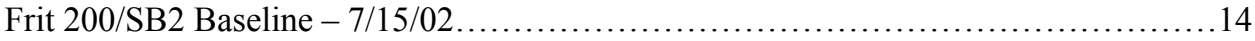

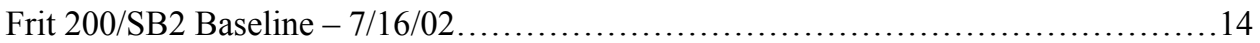

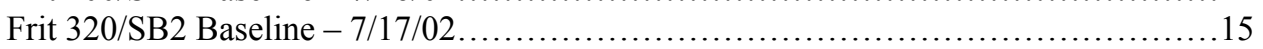

Original SMRF Bubbler Design............................................ 16

Bubbler Location - SMRF Plan View...................................... 16

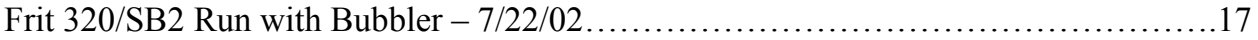

Modified SMRF Bubbler Design........................................... 17

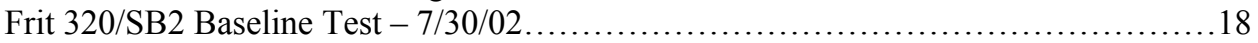

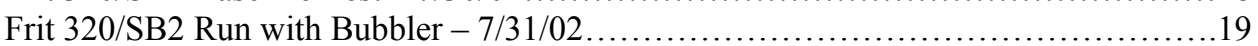

Cold Cap and Vent Hole - Frit 320/SB2 Run - 7/31/02 ............................. 19

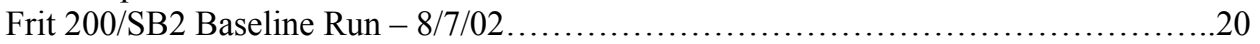

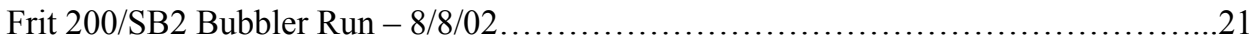

XRD Pattern of the Melter Glass Pool Surface Layer of the Frit 320 Tests..............23

Fired crucibles from the assessment of melt rate and batch expansion................26

(foaming) of SB2 with Frits 200 and 320, plus uranium.

Plot of Waste Throughput for Frit 320 with SB2 as a Function of......................26

\section{LIST OF TABLES}

Table 3-1

Table 3-2

Table 3-3

Table 3-4

Table 3-5

Table 3-6

Table 3-7

Table 3-8

Table 3-9

Table 3-10
Semi-quantitative Melt Rates for the Baseline Tests in the MRF .......................

Semi-quantitative Melt Rates for Each Waste Loading................................. 8

Waste Throughput as a Function of Waste Loading ................................... 9

Semi-quantitative Melt Rates for the Frit Particle-size Tests in the MRF...............11

Semi-quantitative Melt Rates for the Baseline Tests in the TLF........................12

SMRF Melt Rate Tests........................................................ 12

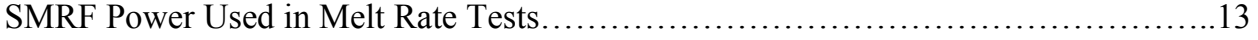

Black Frit Composition................................................................ 20

Frit 320 and Frit 200 Melt Rate Comparison........................................22

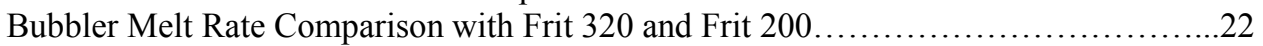




\section{EXECUTIVE SUMMARY}

A study performed in FY01 recommended that the Defense Waste Process Facility (DWPF) replace Frit 200 with Frit 320 for the processing of sludge batch 2 (SB2) to improve melt rate (Lambert et al., 2001) contingent upon additional testing which included slurry feeding. The FY02 melt rate program was developed to support this recommendation as well as to investigate alternative methods of improving melt rate above and beyond a change in frit composition. The integrated program was primarily based on a sound testing methodology from which the frit change was recommended. In addition, the program included the development of additional tools to provide further insight into melt rate enhancements. The overall strategy of the FY02 testing program was to design suites of melt rate tests based on recommendations from previous work that provided insight into other methods of improving melt rate for the DWPF.

The first suite (referred to as baseline tests) involved the assessment of Frits 200 and 320 with two different sludge types at constant waste loading $(25 \%)$. This test series provided a sound technical basis from which additional factors could be assessed and a relatively measure of melt rate determined.

The second suite of tests specifically focused on the Frit 320/SB2 system. Given Frit 320 was developed for a specific WL (25\%), higher waste loading tests were conducted to assess the impact of increased WL on melt rate. The third suite of tests investigated the potential to utilize batch chemicals instead of a prefabricated frit to enhance melt rate. The last suite of tests assessed the impact of frit particle size on melt rate. The objective of this test series was to determine if a change in frit particle size from the standard -80 , +200 mesh, would benefit melt rate for SB2.

All of these tests were performed in the 4" melt rate furnace (MRF). As dry-fed testing progressed, a slurry-fed melt rate furnace (SMRF) was developed and implemented into the overall strategy to assess the impacts of slurry-feeding on melt rate. The primary concern was that the observations or trends observed in the dry feed tests might not be representative of a slurry-feed process. The major phenomena evaluated in the SMRF were the melt and cold-cap behavior, foaming potential, and the impact on melt rate and waste throughput. The tests performed in the SMRF included the baseline tests with Frits 200 and 320, plus tests introducing a bubbler to the system in an effort to increase heat transfer to the cold-cap region

The melt rate investigations performed in FY02 indicate the following:

\section{Dry-fed Melt Rate Testing:}

- Results obtained with the MRF for the baseline tests showed the same trends observed during FY01 testing - Frit 320 melts faster ( 20-35\%) than Frit 200 at a fixed waste loading.

- The results of the higher waste loading tests for the Frit 320/SB2 system indicate that melt rate decreases as waste loading (WL) increases. Although melt rate may decrease as WL increases for the Frit 320/SB2 system, the waste throughput per unit time goes through an "optimum". At a WL of 38\% or less, waste throughput is actually equal to or greater than the baseline $(25 \% \mathrm{WL})$ rate. Waste loadings exceeding the $38 \%$ level had lower throughputs than the baseline. This suggests that one should assess or evaluate the total waste throughput for acceptability criteria, as this is the primary mechanism to support the accelerated clean-up mission. More specifically, during an assessment of the impacts of waste loading on melt rate, decisions on frit selection or targeted waste loading should not be made solely on the relative melt rate. The decision should consider the total sludge throughput per unit time.

- The use of batch chemicals instead of a pre-fabricated frit for the processing of SB2 is not recommended (based solely on dry-feed testing). Significant foaming resulted during all dry-fed tests with batch chemicals. The use of the Purex sludge may have confounded these results, but it is not likely. Further testing in the SMRF with SB2 feed is necessary to support this position.

- It is also not recommended to make a change in the particle size of the frit currently being utilized by the DWPF. A frit finer than the current $-80,+200$ mesh-sized frit melted at approximately the same rate, while a slower melt rate was observed with a larger particle-sized frit. 
- Thermal analyses of all tested batches indicate that there are slight differences in the amount of energy (heat) required to melt tested materials (within each suite of tested materials). Those differences arose in the peaks, but not in the regions of transition (peaks occurred at approximately the same temperature), which was expected. Larger differences arose in the weight $\%$ remaining. A smaller weight $\%$ remaining means greater loss of water and more offgassing during melting.

- Including uranium in the batch did not appear to affect the melting behavior of SB2 with Frit 200 or 320 at a $25 \%$ WL (crucible tests). No foaming or batch expansion occurred, which suggests that uranium has very little effect on the melt rate of SB2.

\section{Slurry-fed Melt Rate Testing}

- The SMRF tests indicated that the Frit 320/SB2 systems melts $\sim 35 \%$ faster than Frit 200/SB2. The difference in melt rate was contributed to major differences in the melting and cold cap behaviors. The Frit 200 cold cap was very rigid, appeared thicker, and appeared to contain a large void volume. The cold cap observed with Frit 320 appeared thinner and was somewhat deformable. Both cold caps contained a significant amount of foam.

- The increased melt rate based solely on a frit change (at constant WL) is consistent with the initial crucible-scale and MRF tests and the 786-A Mini-melter demonstration. This gives a higher level of confidence that the implementation of Frit 320 in DWPF should result in an enhanced melt rate or higher waste throughput.

- Based on previous SMRF tests, it was expected that melt rates could be compared by the feed rates. This appears to work reasonably well with the same frit/waste combination but does not adequately represent melt rate when there is a frit change that significantly alters melting behavior. Glass production is a better measure of melt rate for this situation.

- Slurry-fed tests with the bubbler indicate that melt rate can be enhanced with greater heat transfer to the cold cap region. A melt rate increase of almost $9 \%$ was observed when the mini-bubbler was used with Frit 320/SB2.

- The results indicate that the SMRF is a valuable tool for the determination of melting behavior and melt rate for various frit / sludge combinations. This is a tool that should be integrated into the development of an integrated flowsheet as various frit / sludge combinations are considered or alternative processing strategies are assessed. 


\subsection{INTRODUCTION}

Fundamental work is needed to better understand the effects of feed chemistry, rheology, and process chemistry on melting behavior for DOE high-level waste (HLW) and low-activity waste (LAW) glasses. Melt rate furnace testing is being conducted with the goal of improving melt rate, but also to establish an improved understanding of parameters controlling melt rate. Presently, 4" dry-feed melt rate furnace (MRF) and slurry-fed melt rate furnace (SMRF) tests are being used to obtain relative melt rate behavior and to reduce the risk that no major differences are observed from dry-fed to slurry-fed systems. Melting behavior and foaming potential were evaluated using both melt rate furnaces, while the effects of slurry feeding and the associated cold-cap chemistry will be assessed with the SMRF.

Glass melting is a complex process that involves a number of reactions and transformations, and its rate or behavior can only be described considering all related processing properties. Given that, one needs to establish or identify the relevant processes that impede melt rate for a given system and focus research and development efforts on potential mitigation techniques. Melt rate is defined as how quickly feed materials are converted to a liquid melt (i.e., the rate of the batch-to-glass conversion process) which is ultimately linked to glass throughput.

The focus of this research is to enhance the basic understanding of the role of glass chemistry and/or acid addition strategy changes on the overall melting process for the Defense Waste Processing Facility (DWPF). More specifically, by controlling the chemistry of the incoming feed materials (e.g., in particular the frit composition for a given sludge) or by adjusting chemical processing strategies (e.g., formic or nitric acid relative to the current flowsheet), the conversion rate of slurry-fed raw materials into a molten state can be increased. Intermediate reaction products and/or the development of an insulating foamy layer which can impede the melting rate can be avoided by altering the reaction pathway within the cold cap. If successful, the result is an enhanced melting process which increases throughput without compromising the quality of the final waste form.

Increased melting efficiencies decrease overall operational costs by reducing the immobilization campaign time for a particular waste stream and the entire DWPF process. For melt rate limited systems, a small increase in melting efficiency translates into significant savings by reducing operational costs. Assuming that the DWPF is melt rate limited, it has been estimated that a $10 \%$ increase in melter throughput (melt rate) would reduce the DWPF's overall processing time by almost two years, translating to an $\$ 860 \mathrm{M}$ savings in life cycle costs (based on cost information provided in the Savannah River Site High Level Waste System Plan, Rev. 12). The benefit of increased melting efficiencies and the resulting cost avoidance could be applied to other DOE vitrification facilities including future missions at Hanford (adjustments for annual operating cost would be required for each mission).

A study completed in FY01 concluded that an option for the DWPF to improve the melting rate of SB2 is to switch from Frit 200 to Frit 320 (Lambert et al., 2001). This recommendation was contingent upon further testing, specifically slurry-fed testing. Since those initial crucible-scale and MRF tests, Frit 320, along with Frit 200, has been tested in the 786-A Minimelter (Miller, 2002), in the SMRF at the Aiken County Technology Laboratory (ACTL) and Clemson Environmental Technology Laboratory (CETL), and further in the 4" MRF (Stone and Joseph, 2001). The results from these FY02 tests were very consistent with the results reported by Lambert et al. (2001) which indicated that Frit 320 melts faster than Frit 200 for SB2 at 25\% waste loading. Regardless of the testing protocol used, the FY01 and FY02 testing indicated that measured melt rates of Frit 320 were up to 35\% faster than the nominal SB2 feed (Frit 200 based).

Current plans are to implement Frit 320 once the new melter is installed in the DWPF without a change in waste loading (WL) to assess the impact of this frit change on melt rate relative to Frit 200 (assuming all other factors remain constant). This will also provide an initial link between the full-scale melter and the test methodology being used to assess melt rate and guide alternative frit development and acid addition strategy efforts. 
The objectives of the FY02 testing program included how melt rate might be influenced by increases in WL, differences in frit particle size, the use of batch chemicals rather than a pre-fabricated frit, and the impact of uranium. This report summarizes the equipment development and setup, procedures, and results of this testing, and includes recommendations on the processing of SB2 with Frit 320 and future research.

\subsection{EXPERIMENTAL}

\subsection{FEED PREPARATION}

The SRATproduct used in all testing was prepared from either SB2 sludge (a blend of Tanks 8 and 40) simulant or Purex sludge, both of which were non-radioactive - no U, Th, etc. For each suite of tests a specific sludge type was used so objectives could be met without biasing the results due to compositional changes. More specifically, SB2 SRAT product was used in the higher waste loading testing and the frit particle size testing; the Purex sludge was used in the batch chemical testing. Both sludges were used in the baseline tests (dry-fed) in order to establish a baseline from which the impact of "melt rate change" could be assessed. Both feeds had a targeted $\mathrm{Fe}^{2+} / \Sigma \mathrm{Fe}$ ratio of 0.2 . The Purex sludge was used since the SB2 material was in short supply. It was evaluated in baseline tests to compare with Frits 200 and 320, but it did not behave as well (as consistently) as the SB2 SRAT product (foam and volume expansion). This material had already been through a SRAT cycle before it was obtained, so it was just thoroughly mixed before being combined with frit. The preparation process of the second melter feed (SB2 simulant) was composed of three steps: 1) Combining the Tank 8 and Tank 40 sludge and adding trim chemicals to produce Tank 8/40 blended sludge simulant (SB2 sludge), 2) Processing the sludge simulant through a SRAT process, and 3) Combining the SRAT product with frit (Stone and Lambert, 2001).

Stone and Lambert (2001) described all preparation of SRAT product and the melter-feed materials used in the dry-fed tests, which included drying of the material. The only difference in the preparation of the batches of the dry-fed tests and slurry-fed tests arose in Step 3 of the feed preparation process. For the dryfed tests, once the SRAT product was combined with frit, water was removed by drying in an oven at $110^{\circ} \mathrm{C}$ for at least 12 hours. This step obviously was not necessary when making material for the slurry-fed tests. The SRAT product was combined with frit in specified amounts (targeting a specific WL) and then agitated to prevent the solids from settling during feeding to the SMRF.

\subsection{MELT RATE FURNACE (MRF)}

The testing in FY02 began with dry-fed tests before proceeding with slurry-fed tests. Most of the dry-fed tests were performed in the MRF while a top-loading furnace (TLF) was being experimentally set-up and functionally verified. Although the design of the TLF permits unidirectional heat transfer to the batch (the basis for the MRF design), the TLF does have some operational advantages which include the following: (1) The smaller size provides operational access in a standard fume hood and ease of relocation (if necessary), (2) It requires less power although the impact to melt rate is expected to be minimal; and (3) It has a faster heat-up rate which could translate into more tests per unit time without compromising results. The SMRF is being used as an unit that can more effectively and efficiently assess melt rate.

\subsubsection{Equipment Description and Operation}

This section describes a general overview of the MRF and standard procedures utilized while operating the MRF. The MRF is shown in Figure 2-1. The MRF (as well as the SMRF) was designed to mimic the heat transfer characteristics of a large-scale joule-heated melter. That is, unidirectional heat transfer from the bottom to simulate heat transfer from the molten glass pool to the cold cap. The furnace inner chamber is approximately one cubic foot with 1925-watt plate heaters mounted on opposing walls. The insulation consists of approximately 6 " of M-board on all sides of the furnace chamber. The top board has a 6" circular cutout through all layers of insulation to hold a $1200 \mathrm{~mL}$ stainless steel beaker and insulating sleeve in place. The tests were conducted with 6 " deep stainless steel beakers inserted into the cutout so that the top flange of the beaker was just above the top of the furnace. The beaker bottom was approximately flush with the top of the inner furnace chamber. The furnace was heated to approximately 
$1150^{\circ} \mathrm{C}$ with the top opening covered with an insulating block. Once the furnace reached the setpoint temperature, the cover was removed and the beaker containing sufficient material to produce $\sim 500$ grams of glass was inserted.

The temperature in the beaker was measured at four locations: $1 / 2$ ", 1", 2", and 5" from the beaker bottom using Type $\mathrm{J}$ thermocouples. The thermocouple located at 5 " from the bottom was in the vapor space above the initial batch. The furnace inner chamber temperature was also recorded. Once the beaker had been in the furnace for 42 minutes, it was removed from the furnace. This residence time in the furnace was determined during FY01 testing to establish a standard test time for melt rate comparison. All temperature readings were logged utilizing a calibrated Digisense scanning thermometer, set to record temperatures once every five seconds.

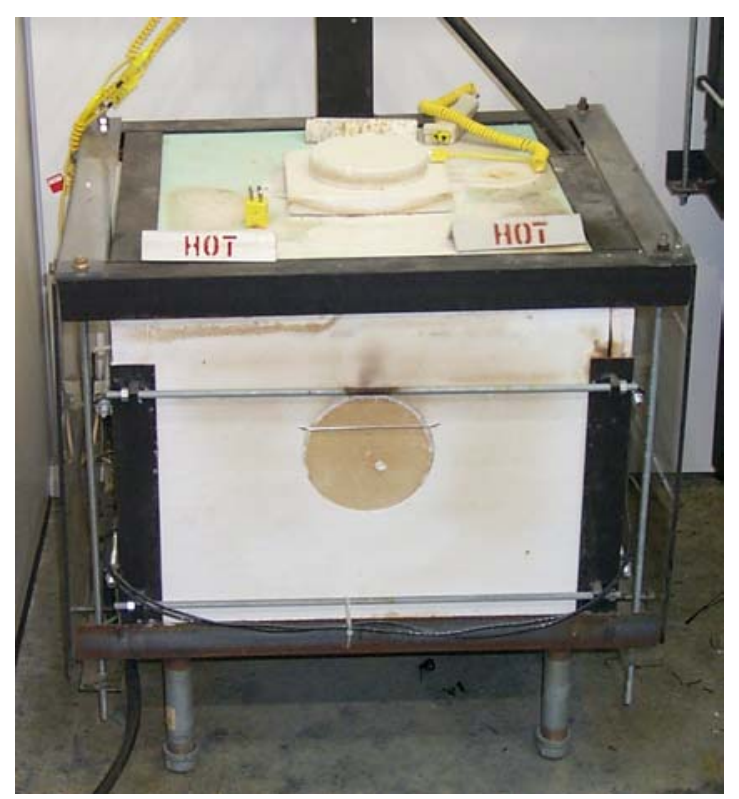

Figure 2-1. The Melt Rate Furnace.

\subsection{TOP-LOADING FURNACE (TLF)}

A second dry-fed furnace was put into use for melt rate testing, with the purpose of eventually replacing the MRF. The TLF is smaller and lighter (therefore easier to move) than the MRF, requires less power, requires less time to reach setpoint, and can be used in a standard-sized fume hood rather than a walk-in hood.

\subsubsection{Equipment Description and Operation}

This section describes a general overview of the TLF and procedures utilized while performing a run with the furnace. The TLF is shown in Figure 2-2. The TLF (as with the MRF and the SFMRF) was designed to mimic the heat transfer characteristics of a large-scale joule-heated melter. That is, unidirectional heat transfer from the bottom to simulate heat transfer from the molten glass pool to the cold cap. The furnace has a cylindrical inner chamber with helically-coiled heating elements embedded within the ceramic fiber insulation. The element is positioned around the sides of the chamber for radial uniformity. Lower outer surface furnace temperatures are achieved through the use of double shell insulation. The chamber diameter is approximately 7.5 " and insulating sleeves were designed to hold a $1200 \mathrm{~mL}$ stainless steel beaker (6" deep) in a position where the bottom of the beaker was approximately flush with the top coil of the heating element (to ensure unidirectional heating). 
Similarly to the MRF, the TLF was heated to $1150^{\circ} \mathrm{C}$ with the top opening covered with an insulating block. Once the furnace reached the setpoint, the cover was removed and the beaker containing sufficient material to produce $\sim 500$ grams of glass was inserted. The temperature in the beaker was measured in four places: $1 / 2$ ", 1", 2", and 5" from the beaker bottom. The residence time of the beaker in the TLF is still being determined though. The residence time for the MRF was 42 minutes, but since the TLF has less power, longer residence times are needed in order to better assess melt rate (approximately 60-65 minutes). The determination of this time was based on results of the baseline tests performed in the TLF. All temperature readings were logged utilizing a Digisense scanning thermometer, set to record temperatures once every five seconds. All observations and changes from the run plan were recorded in a laboratory notebook.

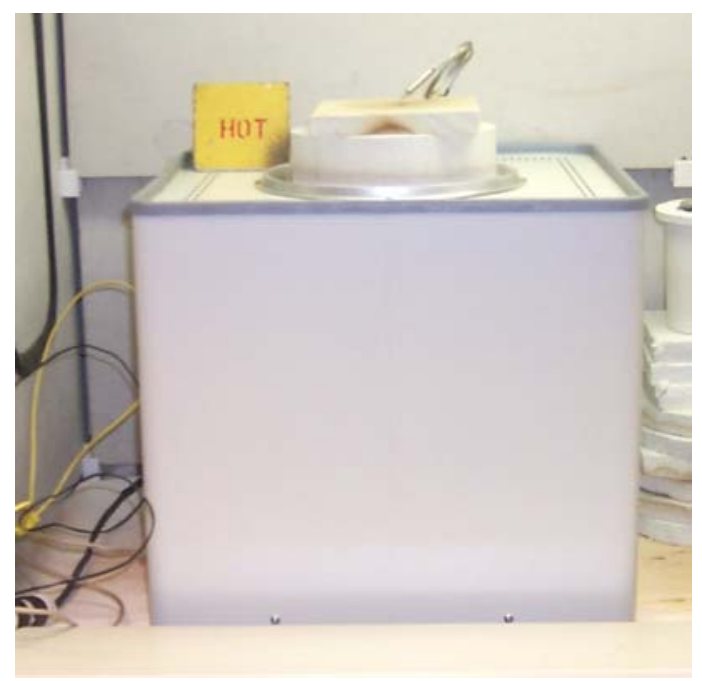

Figure 2-2. The Top-loading Furnace.

\subsection{SLURRY-FED MELT RATE FURNACE (SMRF)}

\subsubsection{Equipment Description and Operation}

The SMRF installed in the high bay of the ACTL has been utilized to compare the melting behavior and melt rate of different slurry feed formulations for the DWPF. The SMRF provides an opportunity for low cost, rapid analysis of process and chemistry alternatives that are under consideration as part of flow sheet improvements and enhancements. In this capacity, tests can be run to assess the impact of reductants, melting temperatures, solids loading.

The slurry-fed melt rate furnace at ACTL is designed to mimic the heat transfer characteristics of a largescale joule-heated melter. This is done by providing heating in one dimension through the bottom of an 8 inch diameter Inconel 690 crucible and insulating around the sides of the crucible in the melt pool area to minimize radial heat transfer to or from the melt pool and heat exchange with the plenum. This mimics the heat flow that would be present in a large melter that relies on convective and conductive heat transfer between the glass pool and cold cap. Sketches of the furnace are shown in Figures 2-3 and 2-4.

The glass temperature is controlled by a thermocouple mounted on the bottom of the crucible and is typically maintained within the temperature range of $1125-1150^{\circ} \mathrm{C}$. Additional heating (separate from that supplied to the melt pool) is applied to the plenum above the melt pool through Globar heaters that surround the top of the crucible. These can be controlled to simulate different plenum conditions in the melter. The plenum temperature is controlled by a thermocouple inserted into the vapor space of the crucible. Automated feed additions to the melter are based on maintaining a plenum temperature set point. After each feed cycle, the controller will wait for the melter to return to the vapor space set point 
temperature (typically $600-800^{\circ} \mathrm{C}$ ). Once the vapor space temperature setpoint has been reached and the temperature is increasing, the feed cycle will begin again. Melt rate can be assessed by measuring the mass decrease of the feed vessel over a test period or by weighing the amount of glass poured over a test period.

The melt rate tests are conducted by feeding the slurry in controlled increments to the SMRF for a sufficient amount of time to establish the cold cap. These conditions are typically achieved after two hours. Melt rate data and observations relating to cold cap and feed behavior are then obtained.

Furnace temperatures, feed tank weight, and glass pour weight data are automatically logged utilizing the Factory Link ${ }^{\mathrm{TM}}$ computer control system. Cumulative power to the lower melt pool and upper-plenum heating elements are indicated by installed Power Analyzers and recorded by the operator as well as by the Factory Link ${ }^{\mathrm{TM}}$ computer control system.

An agitator is used to mix the contents of the melter feed tank and keep the solids in suspension. A peristaltic pump dispenses a predetermined quantity of slurry feed to the SMRF upon command by the Factory Link ${ }^{\mathrm{TM}}$ computer control system. A water-cooled feed tube directs the slurry feed onto the melt pool surface, eventually forming a cold cap.

As the automatic feed system dispenses slurry feed onto the melt surface, glass is continuously poured from the SMRF through the overflow pour tube. The break-over level for glass pouring from the SMRF requires $3 \frac{1}{2}$ inches of glass depth in the crucible. The poured glass is collected in a catch pan located beneath the pour tube discharge. Induction heating is applied to the lower 3 inches of the pour tube that extends beyond the heated chamber of the SMRF to facilitate glass pouring.

One indication of melt rate for a batch composition is determined by the rate at which slurry feed is dispensed from the feed tank to the SMRF. As batch is incorporated into the melt pool, the plenum temperature recovers and subsequent feed cycles are triggered, thus resulting in a reduced feed tank weight. Another assessment of melt rate is obtained by weighing the glass that is poured from the melter through the overflow pour tube. This glass is collected in a pan mounted on scales.

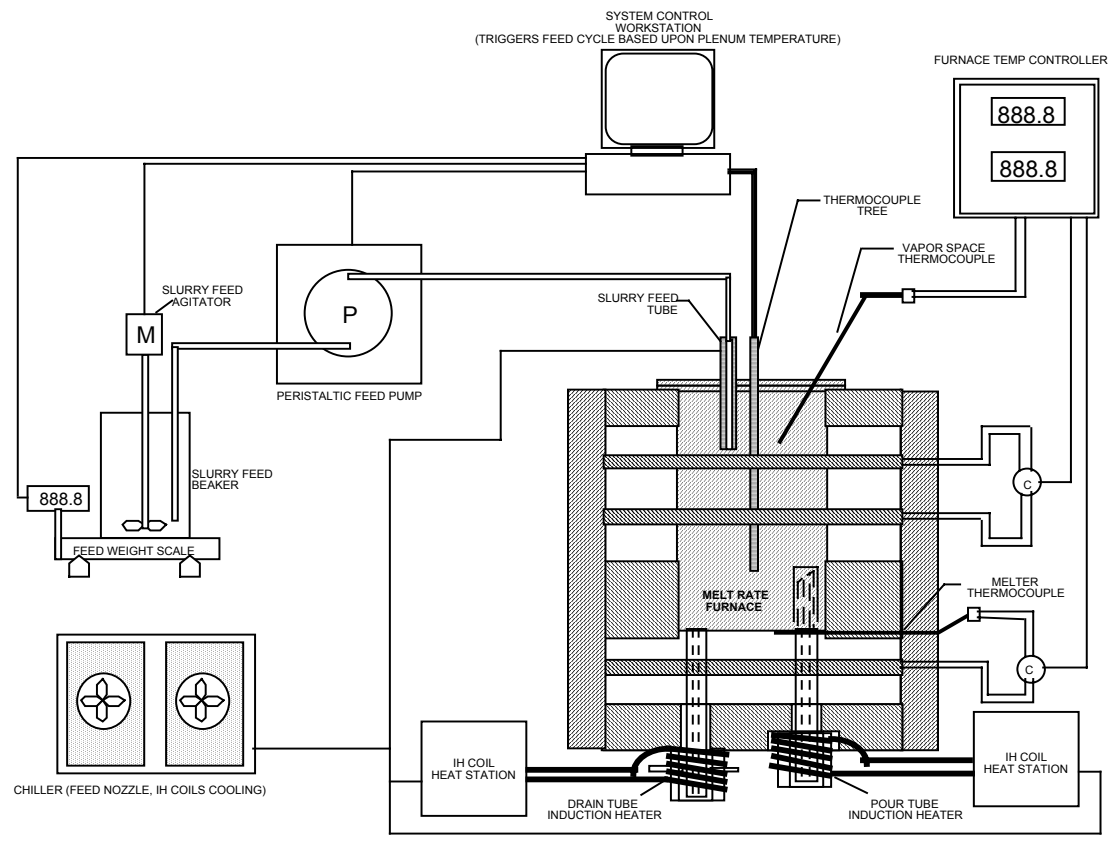

Figure 2-3. SMRF System Schematic 


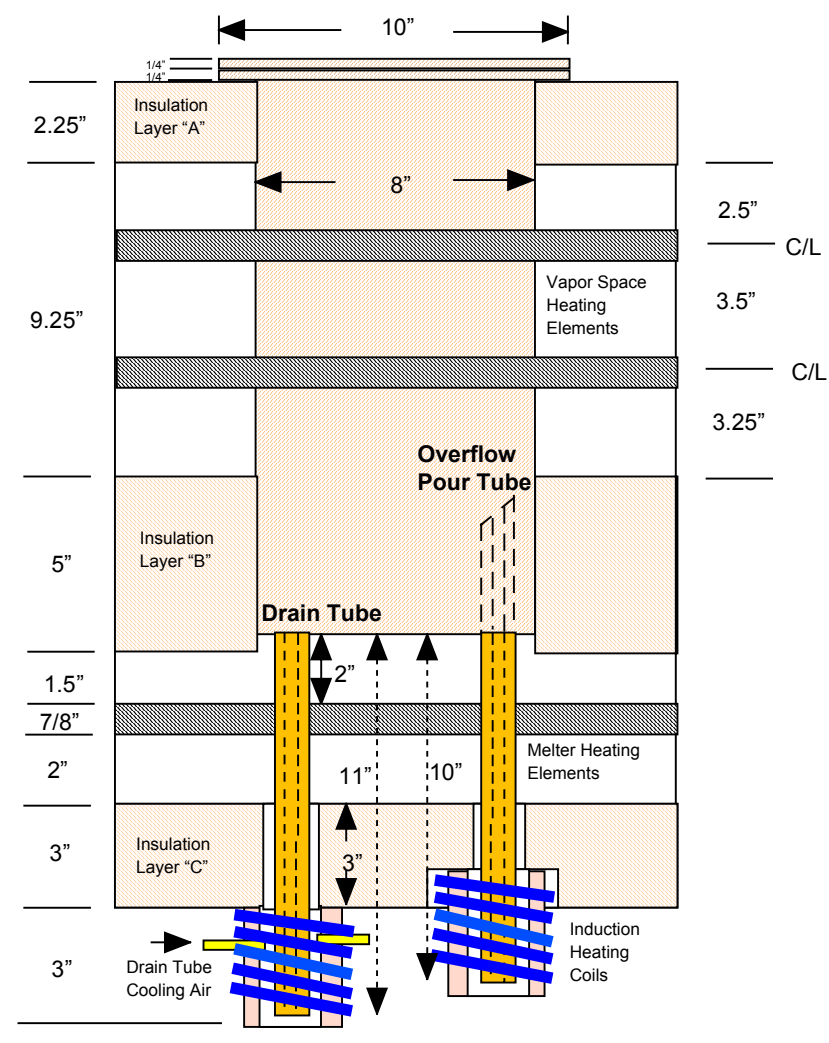

Figure 2-4. ACTL Slurry-fed Melt Rate Furnace

\subsection{DISCUSSION}

\subsection{MRF TESTING}

\subsubsection{Baseline Tests}

The baseline tests consisted of combining Frits 200 or 320 with either Purex feed or SB2 SRAT product (total of four separate tests) at $25 \% \mathrm{WL}$. The purposes of these tests were as follows: 1) To ensure proper operation of the MRF following its relocation to the ACTL, 2) To ensure the same trends in the melting rate of SB2 were obtained as those of FY01 testing (Frit 320 melted significantly faster than Frit 200), 3) To compare the melting behaviors of the Purex feed and SB2 SRAT product, and 4) To establish baselines for comparison with other tests.

The method used to determine the melt rate was to measure the height of the glass pool formed during each test and divide by the run time (consistent with that used by Stone and Josephs, 2001, and Lorier and McGrier, 2002). This same method was used in determining the melt rate when using the TLF as well. The beakers were sectioned in half and the height of the glass pool was measured from the bottom of the beaker to the point where the glass was no longer free of bubbles. Two melt rates were calculated for each run - a linear melt rate and a volumetric melt rate. The linear method involves measuring the glass height at $1 / 4 "$ intervals across the beaker, and then averaging the values to obtain an average glass pool height. The 
average glass pool height was divided by the run time to obtain the melt rate result in inches per hour. The volumetric method involves calculation of the volume of each concentric ring represented by the glass pool height at $1 / 4$ " intervals, and then summing the volume of the rings to obtain the volume of the glass produced during the run. The glass volume was then divided by the run time to obtain a melt rate in cubic inches per hour. The calculated melt rate data for each baseline experiment is presented in Table 3-1.

Table 3-1. Semi-quantitative Melt Rates for the Baseline Tests in the MRF.

\begin{tabular}{l|c|c}
\hline \multicolumn{1}{c|}{ Test } & $\begin{array}{c}\text { Linear melt rate } \\
\text { (in./hr.) }\end{array}$ & $\begin{array}{c}\text { Volumetric melt rate } \\
\text { (in }^{3} / \mathbf{h r} \text {.) }\end{array}$ \\
\hline Frit 200 / SB2 (run \#1) & 0.79 & 12.2 \\
Frit 200 / SB2 (run \#2) & 0.75 & 12.0 \\
Frit 200 / Purex (run \#1) & 0.56 & 8.8 \\
Frit 200 / Purex (run \#2) & 0.79 & 11.0 \\
Frit 320 / SB2 (run \#1) & 1.04 & 12.8 \\
Frit 320 / Purex (run \#1) & 0.93 & 11.1 \\
Frit 320 / Purex (run \#2) & 0.48 & 7.4 \\
\hline
\end{tabular}

As predicted, and as determined in FY01, Frit 320 melted faster than Frit 200 with SB2 as designed (semiquantitatively the same) at $25 \%$ WL. The average linear and volumetric melt rates for Frit 200 are 0.77 and 12.1, respectively. The linear and volumetric melt rates for the Frit 320 glasses are 1.04 and 12.8, respectively. The results suggest a $\sim 35 \%$ increase in melt rate (linear melt rate) based solely on the implementation of Frit 320. The results also confirm that the MRF is a valid tool in making relative comparisons of melt rate. Pictures of the sectioned beakers and temperature profiles appear in Appendices $\mathrm{A}$ and $\mathrm{B}$, respectively, of each of these baseline tests, along with all other dry-fed tests performed in FY02.

A comparison between the two frits when coupled with the Purex feed provides insight to a reproducibility issue. The results indicate that the Purex feed did not melt as well or consistently as the SB2 SRAT product, as evidenced by the significant differences measured between runs \#1 and \#2 with each frit. Given this result, if sufficient quantities of SB2 SRAT product were readily available, all tests would have been based on this single composition. Unfortunately, this was not the case and the Purex feed was required to support the testing program. It was determined that the Purex feed would be utilized in the batch chemical tests given the lower emphasis of these tests with respect to other planned tests. Therefore, the results presented for the batch chemical test series should be viewed accordingly and/or used with caution. Based on the observations of the batch chemical tests though, it is believed the same results would occur with any sludge in a dry-fed system.

\subsubsection{Higher Waste Loading Tests}

Increasing the WL in the glass is desirable to reduce the amount of glass generated and ultimately the number of canisters disposed of in the HLW repository (Lorier and McGrier, 2002). Given that WL has typically been limited by predictions of liquidus temperature $\left(T_{L}\right)$, the Savannah River Technology Center developed a new $\mathrm{T}_{\mathrm{L}}$ model. This new model allows for higher waste loadings to be achieved not only for SB2, but possibly for future sludge batches as well (Brown et. al., 2001). Tests of higher waste loadings were performed in the MRF targeting waste loadings of $27-41 \%$ (in $2 \%$ increments) to determine the impact on melt rate of increasing the waste loading for the Frit 320/SB2 system (Lorier and McGrier, 2002).

Since the issuing of that report, further investigations into the effects of higher waste loading on melt rate were performed in the MRF. Additional testing was performed with the specific objectives assessing reproducibility and to fill some data gaps where critical melt rate changes were observed - specifically between $37 \%$ and $39 \% \mathrm{WL}$, where there was a decrease in melt rate. To meet these objectives, $33 \%$ and $35 \%$ waste loadings were replicated (to the extent possible) and a $38 \% \mathrm{WL}$ run was added. 
As indicated by the following data (see Table 3-2), the data for the replicate $33 \%$ and $35 \%$ tests (labeled as \#2) suggest that both the linear and volumetric melt rates were very reproducible. The results of the $38 \%$ WL test fit the trends of the previously collected data well. The results of all higher waste loading tests are listed in Tables 3-2 and 3-3, and displayed in Figures 3-1 and 3-2 (the data points for the 33\% and 35\% WLs are the averages of each). Also, the melt rate data for Frit 200 and SB2 at 25\% WL have been added to the figures to emphasize the effect of switching from Frit 200 to Frit 320.

Table 3-2. Semi-quantitative Melt Rates for Each Waste Loading.

\begin{tabular}{c|c|c}
\hline $\begin{array}{c}\text { Waste } \\
\text { loading }\end{array}$ & $\begin{array}{c}\text { Linear melt rate } \\
\text { (in./hr.) }\end{array}$ & $\begin{array}{c}\text { Volumetric melt rate } \\
\text { (in }^{\mathbf{3}} / \mathbf{h r} \text {.) }\end{array}$ \\
\hline $25 \%$ & 1.04 & 12.8 \\
$27 \%$ & 1.04 & 13.1 \\
$29 \%$ & 0.92 & 12.1 \\
$31 \%$ & 0.93 & 11.7 \\
$33 \%(\# 1)$ & 0.81 & 12.4 \\
$33 \%(\# 2)$ & 0.85 & 11.4 \\
$35 \%(\# 1)$ & 0.89 & 11.6 \\
$35 \%(\# 2)$ & 0.85 & 10.6 \\
$37 \%$ & 0.82 & 10.6 \\
$38 \%$ & 0.69 & 9.7 \\
$39 \%$ & 0.56 & 8.8 \\
$41 \%$ & 0.58 & 8.7 \\
\hline
\end{tabular}

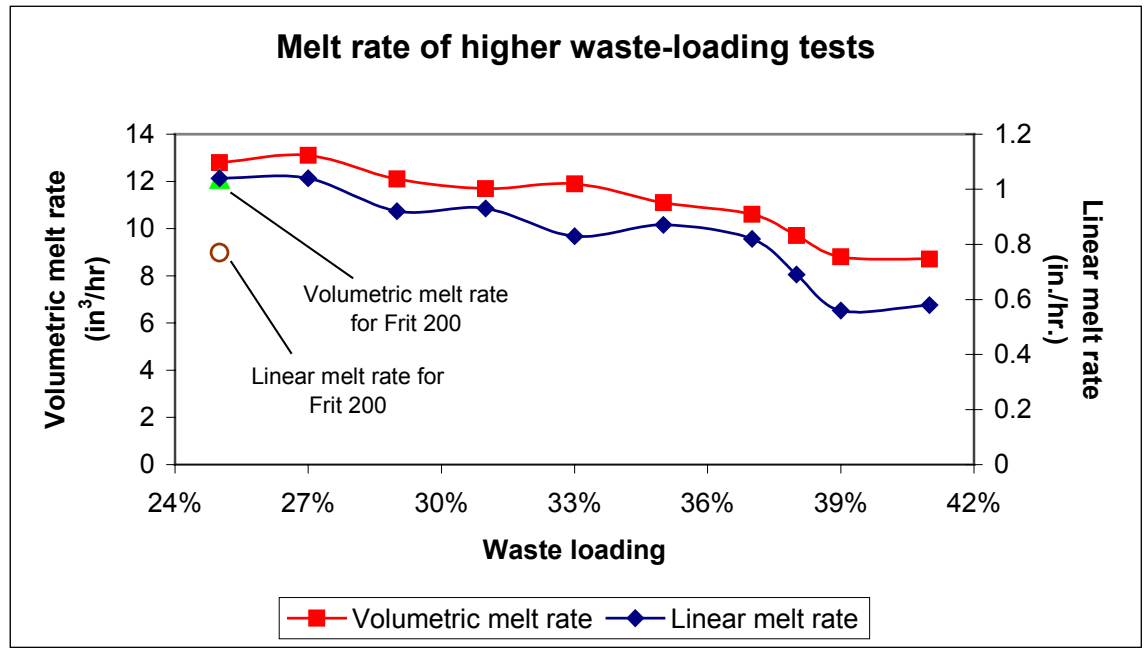

Figure 3-1. Plot of the Melt Rate Data for Frit 320 with SB2 as a Function of Waste Loading (Data from Table 3-2).

As shown by the data, the general trend is that melt rate decreases as WL increases (based on either the linear or volumetric melt rates). By increasing the ratio of waste to frit, less flux (less alkali) is added to the system. This is the opposite compositional direction to improve melt rate based on the hypothesized mechanism for the melt rate improvement between Frit 200 and Frit 320 at 25\% WL. Stone and Josephs (2001) explain the preliminary relationship that an increase in alkali correlates strongly to an increase in melt rate.

Even though melt rate may decrease as WL increases as indicated above for the Frit 320 / SB2 system, the waste throughput per unit time may not (Lorier and McGrier, 2002). However, the idea that "reduced melt 
rates at higher waste loadings is unacceptable" should be tempered with an evaluation of the total waste throughput. More specifically, during an assessment of the impacts of waste loading on melt rate, decisions on frit selection or targeted waste loading should not be made solely on the relative melt rate. The decision should consider the total sludge throughput per unit time.

The data in Table 3-3 and Figure 3-2 can be used to assess the dependence of WL and melt rate on total waste throughput. Waste throughput was calculated via Equation 1, and assuming the amount of waste glass processed per hour by the DWPF is approximately 170 pounds.

$$
\text { Throughput }_{W L \# 2}=170\left(\frac{L M R_{W L \# 2}}{L M R_{25 \% W L}}\right)(W L \# 2)
$$

The waste loading of interest is WL\#2, Throughput $\mathrm{WL}_{2}$ is the waste throughput at that specified waste loading, and LMR is the linear melt rate (values listed in Table 2-2). For example, the waste throughput at $37 \% \mathrm{WL}$ is 49.6 pounds per hour, which was calculated as follows:

$$
\text { Throughput } t_{37 \% W L}=170\left(\frac{0.82}{1.04}\right)(0.37)
$$

Table 3-3. Waste Throughput as a Function of Waste Loading.

\begin{tabular}{c|c}
\hline Waste loading & Waste throughput (lb./hr) \\
\hline $25 \%$ & 42.5 \\
$27 \%$ & 45.9 \\
$29 \%$ & 43.6 \\
$31 \%$ & 47.1 \\
$33 \%$ & $44.8 *$ \\
$35 \%$ & $49.8 *$ \\
$37 \%$ & 49.6 \\
$38 \%$ & 42.9 \\
$39 \%$ & 35.7 \\
$41 \%$ & 38.9 \\
\hline
\end{tabular}

\footnotetext{
* Average waste throughput values for $33 \%$ and $35 \% \mathrm{WL}$.
} 


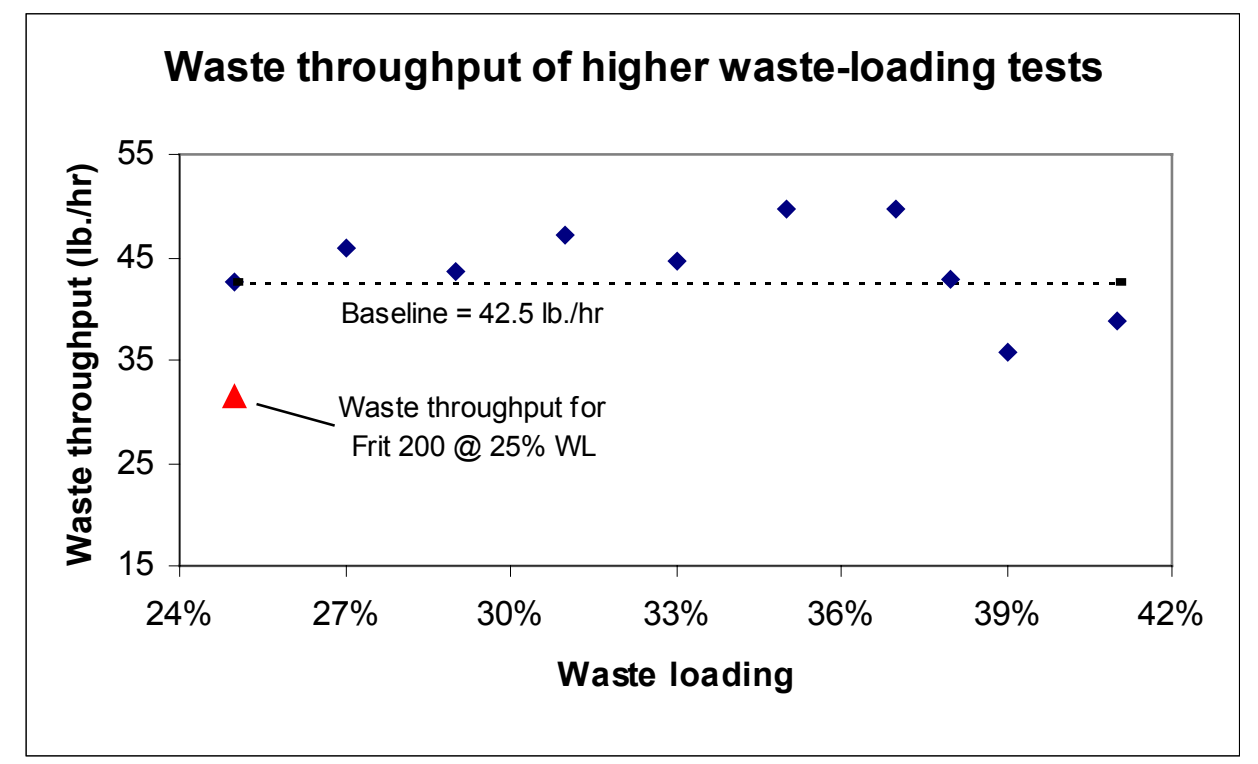

Figure 3-2. Plot of Waste Throughput for Frit 320 with SB2 as a Function of Waste Loading (Data from Table 3-3).

As stated by Lorier and McGrier (2002), the indicated general trend for the Frit 320 / SB2 system is that melt rate decreases as WL increases. However, even though melt rate may decrease as WL increases, the waste throughput per unit time may not. Up to a WL of 38\%, the waste throughput is greater than or equal to the baseline value of $42.5 \mathrm{lb}$./hr (at $25 \% \mathrm{WL}$ ). Waste throughput values for the $39 \%$ and $41 \%$ waste loadings dip below the baseline. This trend indicates that WL can be increased for SB2 with Frit 320, but caution must be used in doing so since melt rate decreases with WL and overall throughput decreases at waste loadings $>39 \%$ (based on dry feed tests). However, it should be noted that the waste throughput values for all Frit 320/SB2 waste loadings are greater than the current Frit 200 based system. To determine if operation above $38 \% \mathrm{WL}$ would be warranted, a cost analysis should be performed to evaluate the competing effects of decreased throughput versus an overall reduction in the number of canisters produced. Also, melting behavior would need to be assessed to evaluate the impact on the DWPF melter stability (offgas pressure surges).

\subsubsection{Batch Chemical Tests}

These tests were designed to determine the impact on melting behavior of switching from prefabricated frit to batch chemical glass formers. It has been hypothesized that batch chemicals can delay the initial formation of a continuous liquid phase until after reactions that produce offgas are complete, significantly reducing the amount of foam formation. This could lead to enhanced melt rates by increasing heat transfer to the batch expediting the batch-to-glass conversion process. In addition, the use of batch chemicals could allow for on-line compositional changes in the glass former composition as processing needs dictate (although this could complicate quality assurance issues). Tests to determine the impact of switching from the prefabricated frits (Frit 200 and Frit 320) to batch chemicals were conducted in the MRF. The composition of each glass former (batch chemicals) targeted its original frit's composition. It should be noted that these tests utilized the Purex SRAT product, which was previously shown to have an erratic melt behavior (see Section 3.1.1). Therefore, the results presented in this section should be viewed accordingly and used with caution.

It was first believed that the batch chemical tests could be conducted by using the exact same constituents as those that go into producing the frit. These included sodium carbonate and lithium carbonate. However, carbonates release large amounts of offgas during melting, and significant foaming occurred during each run - the batch expanded enough to lift the insulating board covering the top of the beaker and the run had to be aborted to prevent damage to the furnace. Thus, a switch was made from the sodium and lithium 
carbonates to lithium nitrate and sodium formate. However, these experiments had to be aborted as well due to excessive foaming. Although not a specific objective of the test, this may provide insight into potential changes to the acid addition strategy. Since none of the batch chemical runs could be taken to completion, no beakers were sectioned and no pictures were taken. As a result of this series of tests, it was decided that the use of batch chemicals is not advised in the dry-feed system. This recommendation was made in light of the erratic melt behavior of the Purex sludge given the excessive volume expansions observed. The testing of batch chemicals in the SMRF would be required (on a more reproducible feed) to determine if melting with batch chemicals could potentially lead to increased melt rate or throughput.

\subsubsection{Frit Particle-size Tests}

The objective for this suite of tests was to determine if the frit particle size impacted the melting process. The frit particle size currently used by the DWPF (and that used as the basis for all other tests in this report) is a mesh size of $-80,+200$. Two alternative size classifications were used in this test series that bound the nominal size currently used: (1) Frit 320 Unders (-200 mesh) and (2) Frit 320 Overs (-25, +60 mesh). The -200 and $-25,+60$ size fractions lead to a small and larger particle size range respectively relative to the nominal $-80,+200$ classification.

Each of these tests targeted 25\% WL and utilized the SB2 SRAT product. The calculated semi-quantitative melt rates for this particle-size testing are presented in Table 3-4. It was originally hypothesized that a smaller particle size might melt faster since the frit would be more readily mixed throughout the entire batch. However, in comparison to the melt rate of the baseline Frit $320(-80,+200$ mesh), the melt rate for the 320 Unders was not greatly different, and that for Frit 320 Overs was slightly less. There is not a significant difference in the melt rates of each particle size of Frit 320 when tested in a dry-feed system.

Table 3-4. Semi-quantitative Melt Rates for the Frit Particle-size Tests in the MRF.

\begin{tabular}{c|c|c}
$\begin{array}{c}\text { Frit particle size } \\
\text { (Frit 320) }\end{array}$ & $\begin{array}{c}\text { Linear melt rate } \\
\text { (in./hr.) }\end{array}$ & $\begin{array}{c}\text { Volumetric melt rate } \\
\text { (in } \mathbf{3} \mathbf{h r} \text {.) }\end{array}$ \\
\hline Standard (-80,+200 mesh) & 1.04 & 12.8 \\
Unders (-200 mesh) & 0.98 & 12.2 \\
Overs (-25, +60 mesh) & 0.79 & 11.5 \\
\hline
\end{tabular}

\subsection{TLF TESTING}

\subsubsection{Baseline Tests}

The baseline tests in the TLF consisted of six tests - combining either Frits 200, 320, or 304 with either Purex feed and SB2 SRAT product at 25\% WL. The objective of this test series was to ensure the same melt rate trends were obtained in this dry-fed furnace (Frit 304 melts faster than Frit 320, which melts faster than Frit 200). The tests ranged in time from 42 minutes to 66 minutes - as previously stated, the TLF has less power than the MRF and any test conducted with it should have a longer beaker residence time. It was concluded though that the same general trends of melt rate for SB2 were achieved with the TLF as with the MRF - Frit 304 melts faster than Frit 320, which melts faster than Frit 200 for SB2; and the Purex material again did not melt as consistently as the SB2 SRAT product (see Table 3-5). Replacement of the MRF with the TLF is still a primary objective given potential operational advantages, but will not prematurely occur until further baseline testing is performed with the TLF to determine a definite residence time. 
Table 3-5. Semi-quantitative Melt Rates for the Baseline Tests in the TLF.

\begin{tabular}{l|c|c}
\hline \multicolumn{1}{c|}{ Test } & $\begin{array}{c}\text { Linear melt rate } \\
\text { (in./hr.) }\end{array}$ & $\begin{array}{c}\text { Volumetric melt rate } \\
\text { (i }^{\mathbf{3}} / \mathbf{h r} \text {.) }\end{array}$ \\
\hline Frit 200 / SB2 & 0.64 & 8.5 \\
Frit 200 / Purex & 0.50 & 7.7 \\
Frit 320 / SB2 & 0.80 & 10.7 \\
Frit 320 / Purex & 0.51 & 7.6 \\
Frit 304 / SB2 & 0.87 & 11.2 \\
Frit 304 / Purex & 0.64 & 9.1 \\
\hline
\end{tabular}

\subsection{SMRF TESTING}

\subsubsection{SMRF Tests}

Eleven melt rate runs were completed in the SMRF for this melt rate task at the ACTL. The planned approach to determining the melt rate for a specific slurry batch composition was to begin with the furnace crucible filled with molten glass of the same (or as close as possible) composition as the slurry batch to be tested. The slurry feed was then metered through the water-cooled feed tube at a rate governed by the vapor space temperature. The vapor space (plenum) temperature was controlled at $750^{\circ} \mathrm{C}$, and the melt pool temperature was controlled at $1125^{\circ} \mathrm{C}$.

As the SMRF vapor space temperature recovered to its $750^{\circ} \mathrm{C}$ temperature setpoint, a feed sequence was triggered by the Factory Link ${ }^{\mathrm{TM}}$ control system. Each feed sequence trigger started the peristaltic feed pump, which in turn operated for a preset amount of time (usually 10-20 seconds) at a preset speed. The feed pump dispensed consistent quantities of slurry batch to the SMRF from a well-agitated slurry feed tank. The weight of the batch feed tank was monitored and was automatically recorded each minute.

Glass was continuously poured from the SMRF through the overflow pour tube and was collected in a catch pan located beneath the pour tube discharge. The eleven melt rate runs are summarized in Table 3-6 and Table 3-7, and each run is discussed in more detail in the sections below.

Table 3-6. SMRF Melt Rate Tests

\begin{tabular}{|c|c|c|c|c|c|}
\hline Date & $\begin{array}{l}\text { Feed type } \\
\text { (frit/sludge) }\end{array}$ & $\begin{array}{c}\text { Total feed } \\
\text { time } \\
\text { (minutes) }\end{array}$ & $\begin{array}{c}\text { Total amount } \\
\text { fed } \\
\text { (grams) }\end{array}$ & $\begin{array}{c}\text { Feed rate } \\
(\text { grams/min) }\end{array}$ & $\begin{array}{l}\text { Glass pour } \\
\text { rate } \\
\text { (grams/min) }\end{array}$ \\
\hline $7 / 09 / 02$ & Frit 200 / Purex & 73 & 3178 & 43.5 & NA \\
\hline $7 / 11 / 02$ & Frit 200 / Purex & $140^{*}$ & 4298 & 30.7 & NA \\
\hline $7 / 15 / 02$ & Frit 200 / SB2 & $65 * *$ & 2988 & 46.0 & NA \\
\hline $7 / 16 / 02$ & Frit 200 / SB2 & $52 * *$ & 2593 & 49.9 & NA \\
\hline $7 / 17 / 02$ & Frit 320 / SB2 & 287 & 11140 & 23.3 & 11.2 \\
\hline $7 / 18 / 02$ & Frit 320 / SB2 & $16^{*}$ & 768 & 48.0 & NA \\
\hline $7 / 22 / 02^{+}$ & Frit 320 / SB2 & $300 * *$ & 12249 & 40.8 & 10.5 \\
\hline $7 / 30 / 02$ & Frit 320 / SB2 & 497 & 21152 & 42.6 & 13.7 \\
\hline $7 / 31 / 02^{+}$ & Frit 320 / SB2 & 269 & 13246 & 49.2 & 14.9 \\
\hline $8 / 07 / 02$ & Frit 200 / SB2 & $295 * * *$ & 14417 & 48.9 & 9.6 \\
\hline $8 / 08 / 02^{+}$ & Frit 200 / SB2 & $337 * * *$ & 16910 & 50.2 & NA \\
\hline
\end{tabular}


Table 3-7. SMRF Power Used in Melt Rate Tests

\begin{tabular}{c|c|c|c|c|c|c}
\hline Run date & $\begin{array}{c}\text { Feed type } \\
\text { (frit/sludge) }\end{array}$ & $\begin{array}{c}\text { Wt\% } \\
\text { feed } \\
\text { solids }\end{array}$ & $\begin{array}{c}\text { Avg. feed } \\
\text { rate } \\
\text { (g/min) }\end{array}$ & $\begin{array}{c}\text { Avg. } \\
\text { plenum } \\
\text { power } \\
\text { (Btu/min) }\end{array}$ & $\begin{array}{c}\text { Avg. melt } \\
\text { pool power } \\
\text { (Btu/min) }\end{array}$ & $\begin{array}{c}\text { Avg. glass } \\
\text { pour rate } \\
\text { (g/min) }\end{array}$ \\
\hline $7 / 17 / 02$ & $320 /$ SB2 & 41.72 & 38.8 & 122.3 & 52.1 & 11.2 \\
$7 / 22 / 02^{*}$ & $320 /$ SB2 & 40.12 & 41.5 & 119.9 & 56.4 & 10.1 \\
$7 / 30 / 02$ & $320 /$ SB2 & 40.12 & 42.9 & 124.9 & 53.8 & 13.7 \\
$7 / 31 / 02^{*}$ & $320 /$ SB2 & 40.12 & 49.2 & 115.1 & 53.1 & 14.9 \\
& & & 48.9 & 137.7 & 50.2 & 9.6 \\
$8 / 07 / 02$ & $200 /$ SB2 & 41.29 & 40.9 & 121.6 & 50.2 & NA \\
\hline
\end{tabular}

\subsubsection{Frit 200/Purex Sludge Feed Characterization Runs}

The initial two melt rate tests with the SMRF (7/09/02 and 7/11/02) used a slurry feed made from Frit 200 and Purex Sludge (Jones et al., 2002 (SRT-GPD-2002-00080)). These runs served to checkout and demonstrate the performance of the newly installed furnace and feed system. The tuning parameters for the furnace power controls were adjusted and tested while feeding this batch, as well as determining the desired feed pump sequence settings. Also, modifications were made to the feed system to eliminate areas where abrupt tubing diameter changes and bends in the tubing path from the feed tank to the feed tube restricted the slurry feed flow.

\subsubsection{Initial Frit 200/SB2 Runs}

The third and fourth melt rate test runs in the SMRF (7/15/02 and 7/16/02) used a slurry feed made from Frit 200 and Sludge Batch 2 (SB2) Simulant (Jones et al, 2002 (SRT-GPD-2002-00085)). The total solids in this feed batch averaged $41.62 \mathrm{wt} \%$. The goal of these runs was to establish a steady state feeding condition and determine a melt rate for the Frit 200 baseline process. The melt pool was maintained at $1125^{\circ} \mathrm{C}$ and the vapor space set point temperature was $750^{\circ} \mathrm{C}$. The slurry feed pump was set to initiate a 10 -second feed cycle at a $200 \mathrm{rpm}$ pump speed each time the vapor space temperature reached $750^{\circ} \mathrm{C}$.

\subsection{Frit 200/SB2 Baseline Melt Rate Test-7/15/02}

After eleven minutes of slurry feeding during the initial test run with Frit 200 and SB2, the water-cooled feed tube plugged. Only 704 grams of slurry had been fed to the furnace when this pluggage occurred. The test was suspended while the feed tube was unplugged and the suction tube in the feed tank was modified by crimping the suction end of the tube and cutting slots parallel to the direction of the slurry flow resulting from the batch agitation. The feed pump tubing was replaced with a larger inside diameter tubing (LS-16 tubing), which caused a change in the pump head. The feed pump speed was adjusted to $265 \mathrm{rpm}$ to match the new tubing flow rate specifications, which resulted in 70 grams of feed being delivered over a 20 second feed cycle.

Initial testing with the Frit 200 and SB2 feed was then resumed. The automatic feed cycle was used to feed 2988 grams of slurry feed over 65 minutes for an average feed rate of 46.0 grams/minute. Though there was not sufficient time to establish a steady-state cold cap, the plugging of the feed line appeared to be eliminated. Feeding information is shown in Figure 3-3. 


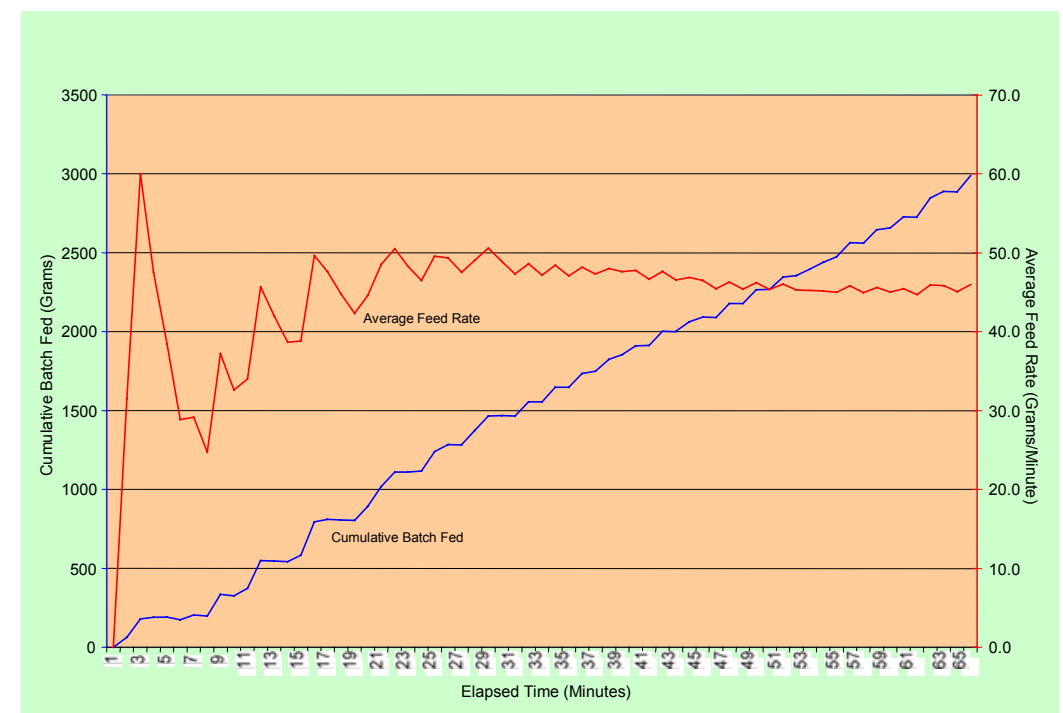

Figure 3-3. Frit 200/SB2 Baseline - 7/15/02

3.3.1.2.2 Frit 200/SB2 Baseline Melt Rate Test-7/16/02

The second baseline Frit 200/SB2 run was continued the following day. The remaining feed material was fed to the melter over a 52-minute period (2593 grams of slurry) for an average feed rate of 49.9 grams/minute (see Figure 3-4). Again, the feeding time was too short to establish a cold cap and determine a feed rate for the Frit 200/SB2 feed. Additional Frit 200/SB2 feed needed to be prepared to allow for the longer, continuous operating time needed to determine a melt rate. Because of the problems that occurred, the results of this particular scoping study with the SMRF was not used in any melt rate determinations or conclusions.

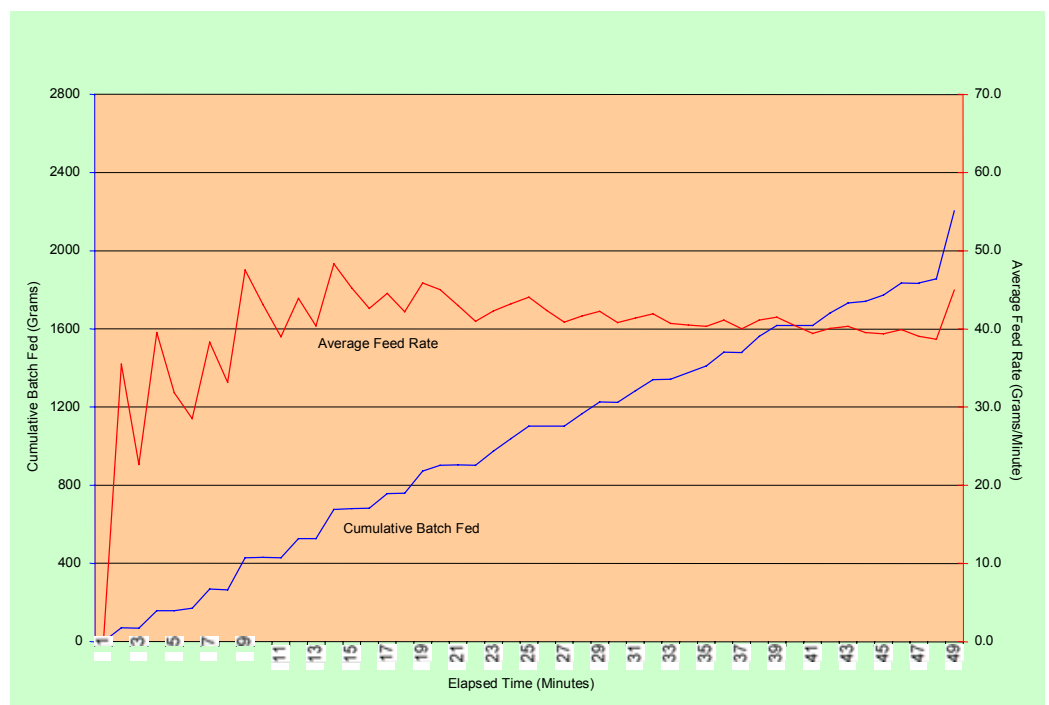

Figure 3-4. Frit 200/SB2 Baseline - 7/16/02 


\subsubsection{Frit 320/SB2 Runs}

The next five SMRF runs were made with Frit 320 and SB2 Simulant (Jones et al., 2002 (SRT-GPD-200200084 and -00102)). The goal was to obtain a melt rate for the Frit 320/SB2 feed with the first two runs, and then evaluate the impact of the addition of an airlift bubbler on melting behavior from the remaining three runs. Consistent with previous tests, the melt pool was maintained at $1125^{\circ} \mathrm{C}$, and the plenum was set to maintain a $750^{\circ} \mathrm{C}$ vapor space temperature. Prior to the first Frit 320 run, the melt pool was drained and then recharged with type 320 black frit (Frit 320/SB2 composition).

\subsection{Frit 320/SB2 Baseline Melt Rate Test - 7/17/02}

The first Frit 320/SB2 run was conducted on 7/17/02. Approximately 11,140 grams of slurry feed was processed in the SMRF in a 5-hour period. At 185 minutes into the run a feed tube pluggage occurred. The plug was cleared in about 15 minutes and feeding resumed. The cumulative amount fed and the feed rate as a function of run time are shown in Figure 3-5. Cold cap formation occurred after 100-120 minutes of feeding, after which the feed rate averaged 38.8 grams/minute.

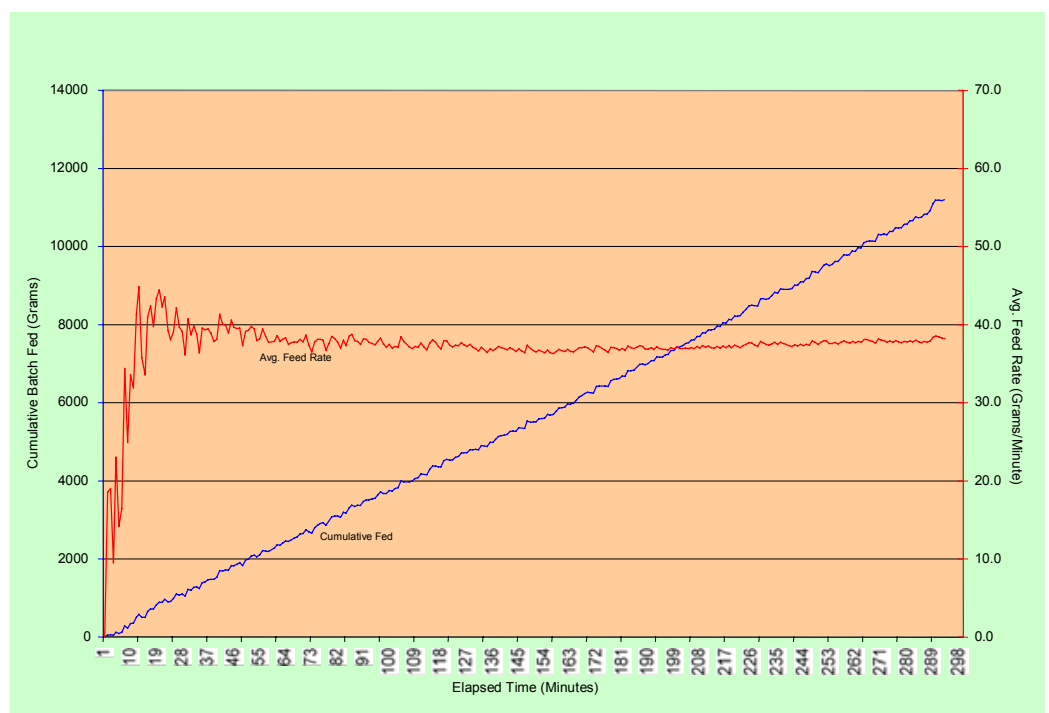

Figure 3-5. Frit 320/SB2 Baseline - 7/17/02

\subsection{Frit 320/SB2 Melt Rate Test With Bubbler - 7/18/02 \& 7/22/02}

On 7/18/02, a mini-airlift bubbler was introduced into the SMRF to assess its effect on melt rate. A schematic of the mini-bubbler used is shown in Figure 3-6. This mini-bubbler consists of a 1/4" Inconel 690 tube welded to a $3 / 4$ " inner diameter (ID) Inconel 690 pipe (draft tube). Air enters the $1 / 4$ " tube and is discharged through two $1 / 32^{\prime}$ " diameter holes spaced $120^{\circ}$ apart and located $1 / 2$ " from the bottom of the draft tube. The resulting air bubbles push molten glass upward through the $3 / 4$ " draft tube and discharge it out the top. For this test the bubbler was positioned vertically with the top of the $3 / 4$ " tube about $1 / 4$ " below the glass surface (glass/cold cap interface) and at the location shown in the SMRF plan view of Figure 3-7. A bubbler flow rate of $35 \mathrm{scc} /$ minute was used for these tests. 

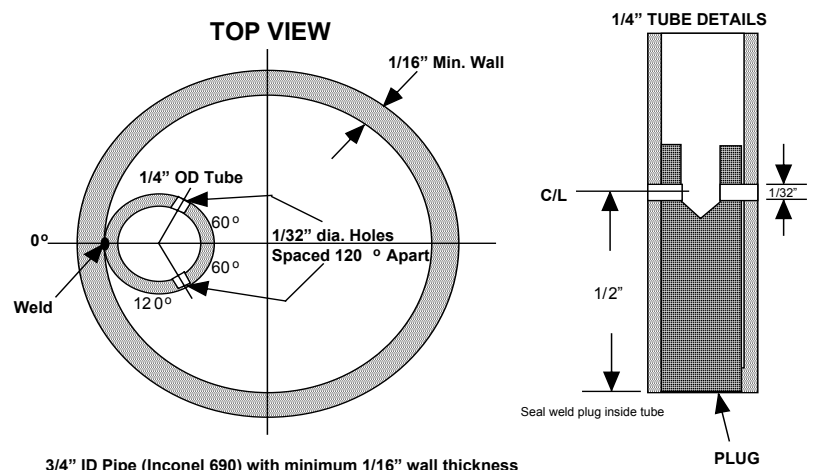

3/4" ID Pipe (Inconel 690) with minimum 1/16" wall thickness

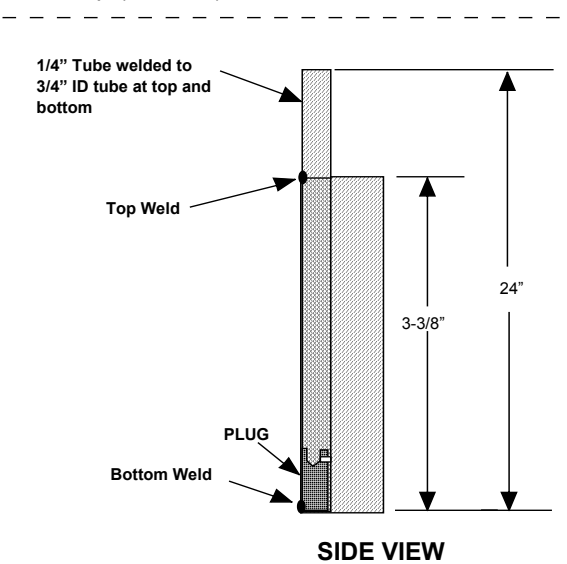

Figure 3-6. Original SMRF Bubbler Design

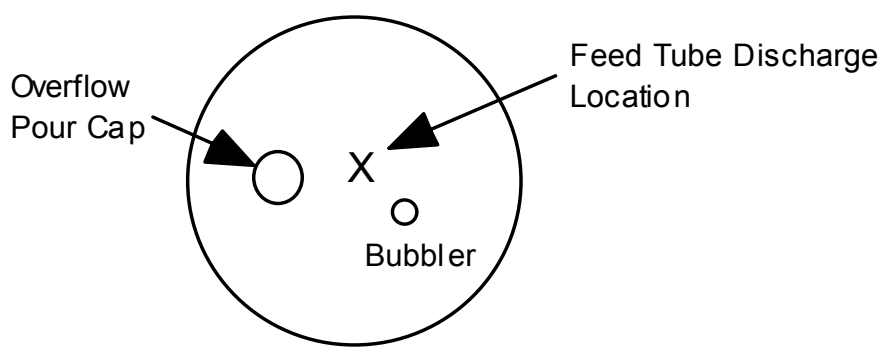

Figure 3-7. Bubbler Location - SMRF Plan View

The feed tube plugged approximately 18 minutes after feeding was initiated. The plug was very difficult to remove necessitating termination of the run. After successfully unplugging and cleaning the feed tube, the mini-bubbler test was restarted on $7 / 22 / 02$. The bubbler was again positioned approximately $1 / 4$ " beneath the glass surface. Airflow through the bubbler was maintained at $35 \mathrm{scc} /$ minute throughout the run. For the initial 35 minutes of feeding the glass could be observed discharging from the top of the bubbler, although the flow appeared to be lower than expected based on mini-bubbler tests conducted in glycerin. At the 35-minute mark, however, the slurry feed covered the vent hole and the cold cap that formed obscured the bubbler. No vent hole was visible above the bubbler for the remainder of the test. Two feed tube plugs were experienced, one at 104 minutes into the run and another at about the 5 hour mark. Approximately 22 minutes were required to clear the first feed tube plug and resume feeding. Again the frequent feed tube plugs prevented extended feeding operation that is required to attain a steady operating 
condition and generate good melt rate information. The cumulative amount fed and the feed rate as a function of run-time are shown in Figure 3-8.

As a result of the problems experienced during this run, two changes were made to the SMRF - one to the feed tube and the other to the bubbler. The water-cooled feed tube was replaced with another feed tube with a larger inside diameter ( 0.187 vs. 0.094 inches in the original tube) to reduce the potential for pluggage. Along with this change the feed pump speed was raised to increase the quantity of feed dispensed per 20 second feed cycle from $\sim 70$ grams to 90 grams. In an effort to increase the glass discharge flow from the bubbler an additional 1/16" diameter discharge hole was added to the bottom of the mini-bubblers air supply tube as shown in Figure 3-9. The two 1/32" holes were not altered.

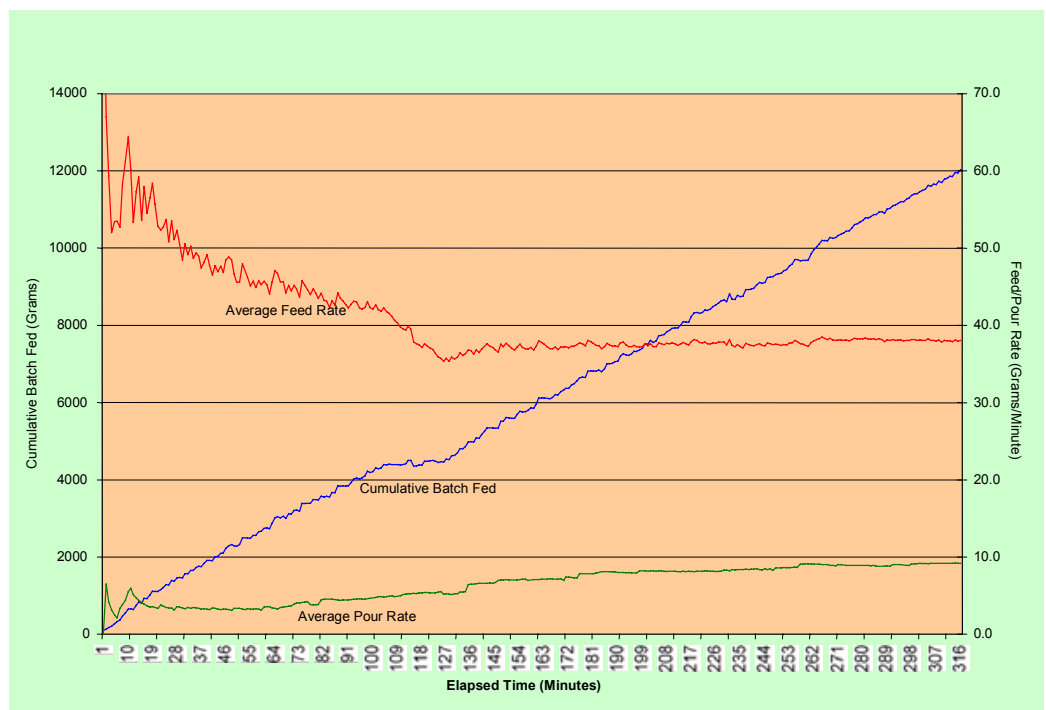

Figure 3-8. Frit 320/SB2 Run with Bubbler - 7/22/2002

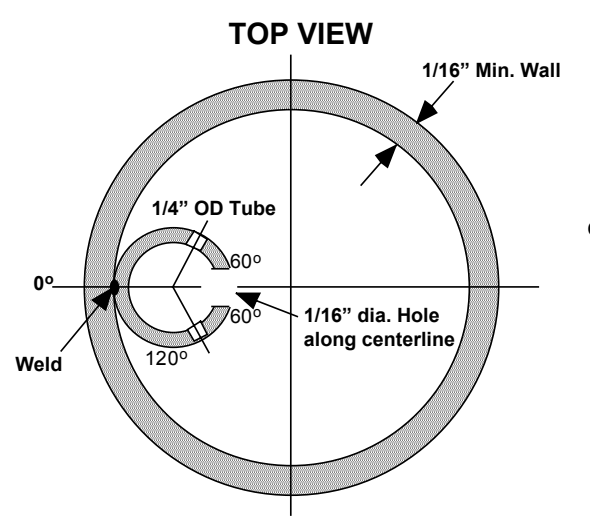

3/4" ID Pipe (Inconel 690) with minimum 1/16" wall thickness

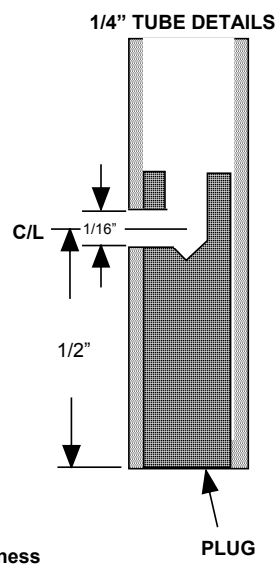

SIDE VIEW

Figure 3-9. Modified SMRF Bubbler Design 


\subsection{Frit 320/SB2 Baseline Melt Rate Test - 7/30/02}

The feed tube change was evaluated in a Frit 320/SB2 baseline run that was conducted on 7/30/02. The SMRF setpoint temperatures remained unchanged - the melt pool at $1125^{\circ} \mathrm{C}$ and the vapor space at $750^{\circ} \mathrm{C}$. Slurry feeding continued for 497 minutes, with a 32-minute interruption caused by a pour tube heater outage that occurred 117 minutes into the run. Figure 3-10 provides a plot of the cumulative amount fed and feed rate. After establishment of the cold cap approximately 100 minutes into the run, the feed rate averaged about 43 grams/minute. The plenum power requirement during this period was $124.9 \mathrm{Btu} / \mathrm{minute}$ and the melt pool power used was $53.8 \mathrm{Btu} /$ minute. The average glass production rate during the period was 13.7 grams/minute. No further feed tube pluggages were encountered.

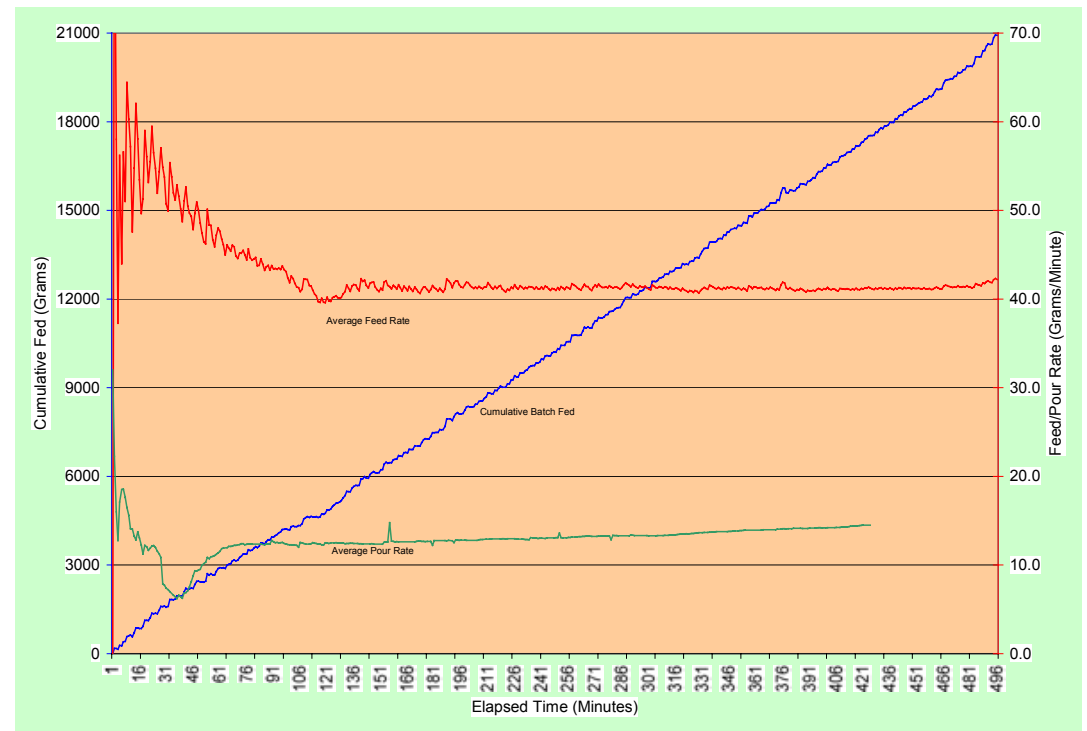

Figure 3-10. Frit 320/SB2 Baseline Test - 7/30/02

\subsection{Frit 320/SB2 Melt Rate with Bubbler - 7/31/02}

On 7/31/02, a Frit 320/SB2 SMRF run was performed using the modified mini-bubbler shown in Figure 39. Prior to initiating slurry feeding, the bubbler was installed in the melt pool at an elevation that placed the top of the discharge tube approximately $1 / 4$ " below the glass surface. The airflow to the bubbler was subsequently set to 10,20,30,40 and $50 \mathrm{scc} /$ minute and the glass discharge flow from the bubbler as well as bubble dissipation was observed at each condition. It was determined by observation of the melt pool surface that the optimal glass movement through the bubbler was achieved between the 10 and 20 scc/minute airflow settings. Therefore, the bubbler airflow was set to $15 \mathrm{scc} / \mathrm{minute}$ to begin the melt rate test.

The bubbler was positioned to match the location given in the melter plan view in Figure 3-7. The SMRF was slurry fed for 269 minutes with no feed or glass interruptions. Figure 3-1 shows the cumulative amount fed and the average feed rate and pour rate as a function of operating time. Consistent with the Frit 320/SB2 baseline test, approximately 100-120 minutes were required to establish a cold cap and reach a steady feeding condition. The feed rate decreased near the 240 -minute mark because of air entrainment caused by a low level in the feed tank. The larger diameter discharge hole on the bubbler air supply tube significantly improved bubbler performance. An increase of $\sim 9 \%$ in melt rate over that of the baseline test was observed with this mini-bubbler (based on a grams/minute basis). No problems with bubble dissipation were evident with Frit 320. The hot glass that discharged from the bubbler maintained a vent hole in the cold cap for the entire run. If feed covered the hole, the vent was re-established within 1 to 2 minutes. The cold cap thickness was between 1 " and $1 \frac{1}{2}$ " and the surface was hard and crusty with a 
somewhat softer under structure. A photo of the cold cap and vent hole is shown in Figure 3-12. Plenum power requirements during feeding were $115.1 \mathrm{Btu} /$ minute and melter power usage was $53.0 \mathrm{Btu} / \mathrm{minute}$.

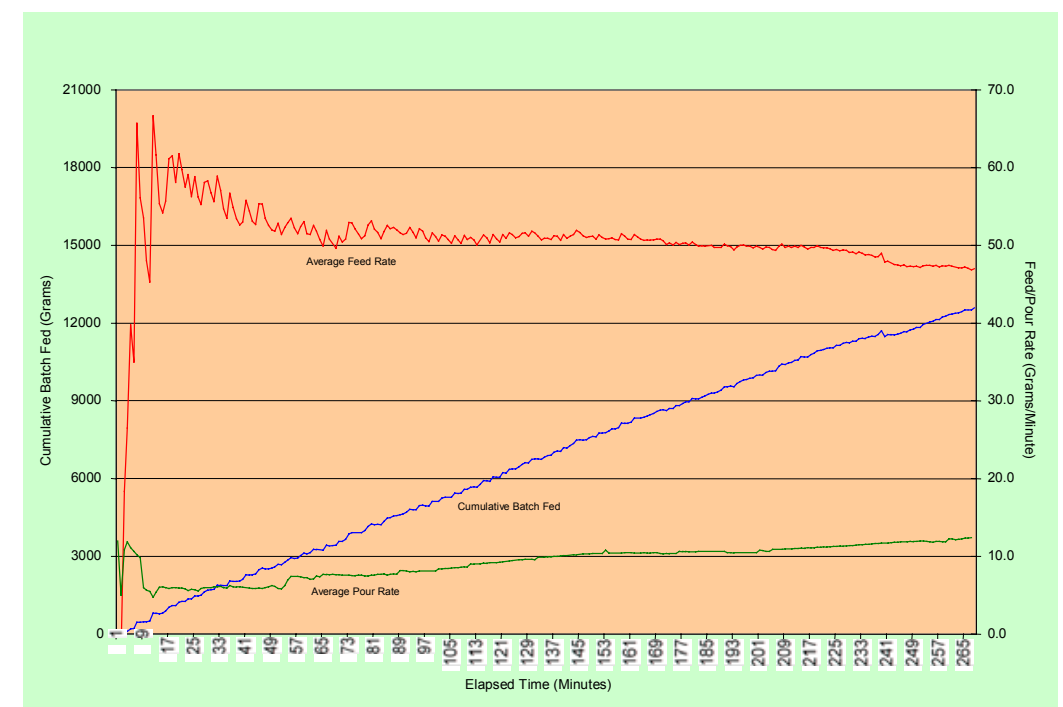

Figure 3-11. Frit 320/SB2 Run with Bubbler - 7/31/02

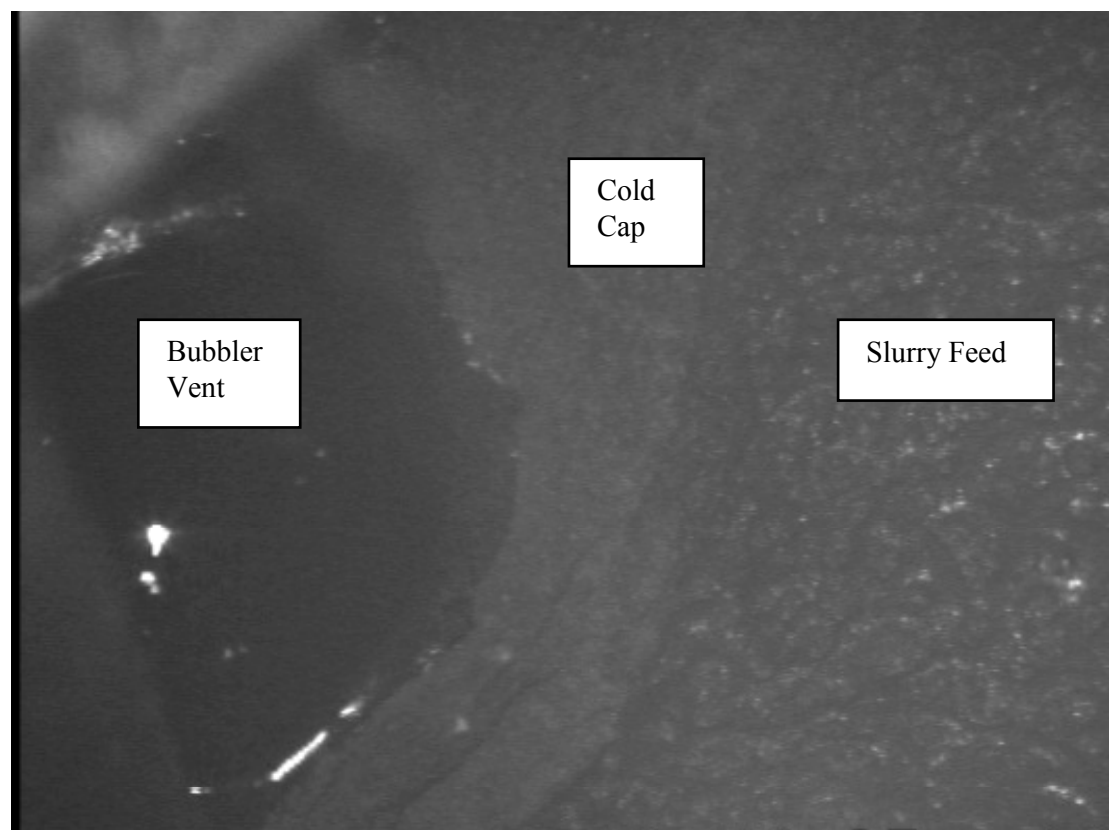

Figure 3-12. Cold Cap and Vent Hole - Frit 320/SB2 Run - 7/31/02

\subsubsection{Frit 200/SB2 Runs}

Melt rate tests with Frit 200/SB2 feed (Jones et al., 2002 (SRT-GPD-2002-00098 and -00103)) were conducted in the SMRF on 8/7/02 and 8/8/02. In preparation for these tests, the SMRF was drained to remove the Frit 320/SB2 glass and was re-charged with 8.5 kilograms of black frit (designated Frit Phase 2 Glass) that was used in the Phase 2 Plutonium can-in-can testing at the Clemson Environmental 
Technologies Laboratory (CETL). The composition of this glass (see Table 3-8) was determined to be a better starting composition for Frit 200 testing than the Frit 320/SB2 glass.

Table 3-8. Black Frit Composition

\begin{tabular}{c|c}
\hline Component & Wt\% \\
\hline $\mathrm{SiO}_{2}$ & 55.5 \\
$\mathrm{~B}_{2} \mathrm{O}_{3}$ & 7.9 \\
$\mathrm{Al}_{2} \mathrm{O}_{3}$ & 6.8 \\
$\mathrm{Fe}_{2} \mathrm{O}_{3}$ & 10.5 \\
$\mathrm{Na}_{2} \mathrm{O}$ & 11.6 \\
$\mathrm{Li}_{2} \mathrm{O}$ & 4.5 \\
$\mathrm{MnO}$ & 1.6 \\
$\mathrm{CaO}$ & 1.6 \\
\hline
\end{tabular}

3.3.1.4.1 Frit 200/SB2 Baseline Melt Rate Test - 8/7/02

The Frit 200 baseline melt rate test was conducted on 8/7/02. The SMRF melt pool and vapor space temperatures were maintained at $1125^{\circ} \mathrm{C}$ and $750^{\circ} \mathrm{C}$, respectively. Slurry feeding continued for 295 minutes with no feeding interruptions. Feed rate and pour rate information is shown in Figure 3-13. As evidenced by the feed rate plot, approximately 100 minutes were required to establish a cold cap. The average slurry feed rate for the Frit 200 feed was $40.17 \mathrm{~g} / \mathrm{min}$., and based on cold cap observations and visual inspection, and probing, it was observed that the SMRF was overfed - i.e., feed rate exceeded melt rate. A thick crusty cold cap was formed that had a depth that ranged from 2" to as much as $3 \frac{1}{2}$ ". These observations agreed with the low glass production rate $(9.6 \mathrm{~g} / \mathrm{min})$. Over the time interval of $100-300$ minutes, 1894 grams of glass were produced versus an expected amount of 3452 grams. Approximately 1558 grams of material were held up in the unmelted, rigid cold cap. The average vapor space and melt pool power usage was $137.7 \mathrm{Btu} /$ minute and $50.2 \mathrm{Btu} /$ minute, respectively, over the time period of 105-285 minutes.

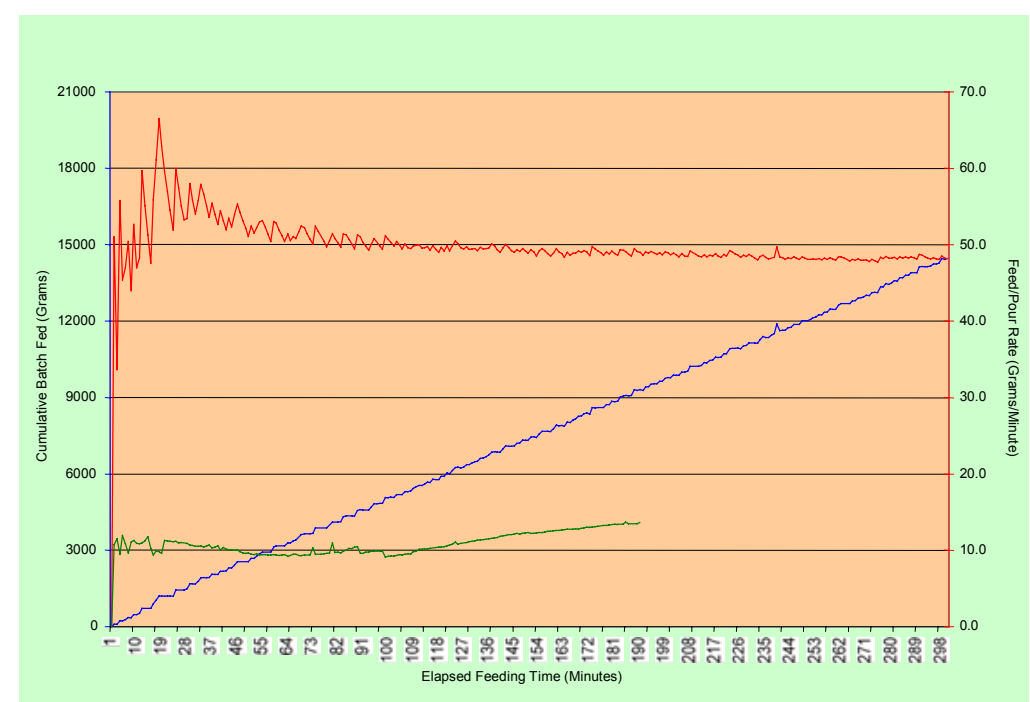

Figure 3-13. Frit 200/SB2 Baseline Run - 8/7/02 


\subsection{Frit 200/SB2 Melt Rate Test with Bubbler - 8/8/02}

A mini-bubbler test using Frit 200 and SB2 was conducted in the SMRF on 8/8/02. The bubbler was installed in the same location ( $\sim 1 / 4$ " beneath the glass/cold cap interface) as in the previous tests with Frit 320. Airflow through the bubbler was maintained at $15 \mathrm{scc} / \mathrm{minute}$ throughout the entire test, and slurry feeding was maintained for 337 minutes with no interruptions. Feed rate and cumulative feed information are plotted in Figure 3-14. As in earlier SMRF runs, about 100 minutes were required to establish a cold cap and steady feeding conditions. The apparent feed rate $(50.2 \mathrm{~g} / \mathrm{min})$ was comparable to that obtained with Frit 200/SB2 without a bubbler (48.9 g/min), and appeared higher than for Frit 320/SB2 (49.2 g/min with bubbler, $42.6 \mathrm{~g} / \mathrm{min}$ without bubbler). As in the previous Frit 200 run without a bubbler, it was observed that the SMRF was overfed. A very thick (2-4 inches) cold cap formed that had a hard, crusty top surface.

Bubbler performance was quite different with the Frit 200-based system as compared to the Frit 320 system. The bubbler vent hole was quickly covered by the formation of the cold cap. The hot glass being discharged from the bubbler draft tube was not sufficient to keep the vent open. As a result, the melt pool was pressurized by the bubbler air resulting in significantly more glass being poured than expected (4295 grams poured versus 3635 grams expected). The average glass pour rate cannot be used due to pressurizations caused by the bubbler that falsely elevated the pour rate. The bubbler elevation was raised $1 / 4$ " putting it at the glass cold cap interface, but an opening of the vent hole was not achieved. The thick, crusty cold cap hindered further vertical movement of the bubbler and the $3 / 4$ " bubbler discharge tube could not be moved up into the cold cap. No discernable melt rate increase was observed when the mini-bubbler was relocated with the Frit 200-based system. The feed rate with and without a bubbler were essentially the same and the pressurized pour with the bubbler negated obtaining useful information from glass production measurements. Plenum power input and melt pool power input were $121.6 \mathrm{Btu} / \mathrm{minute}$ and 50.2 Btu/minute, respectively, over the 100-355 minute time frame.

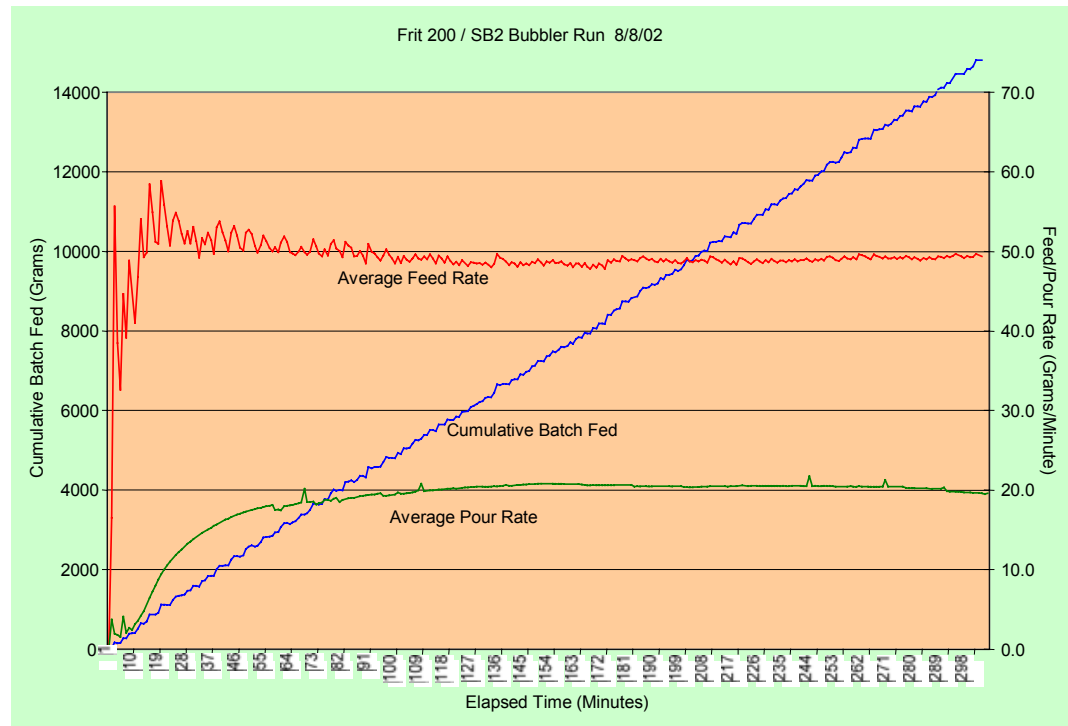

Figure 3-14. Frit 200/SB2 Bubbler Run - 8/8/02

\subsubsection{Melt Rate Comparison of Frit 320 and Frit 200 with SB2}

Baseline tests were conducted in the SMRF using SB2 with Frit 320 and Frit 200 to compare melt rate and melting behavior. Results from these tests are summarized in Table 3-9. The observed melting behaviors for Frit 320 and Frit 200 were quite different as were the melt rates. For both frits, approximately 100 minutes were required to establish a cold cap and reach a steady feeding condition. Therefore, melting 
comparisons were made neglecting the first 100 minutes of feeding. Glass production for Frit 320 was approximately $40 \%$ higher than that of Frit 200 , which follows the trends observed previously with the dryfed melt rate furnace and the 786-A Mini-melter. The feed rate, however, was much higher for Frit 200, but because of the poorer melting behavior and lower melt rate, a significant overfeeding situation resulted producing a very thick and crusty cold cap. In contrast, Frit 320 produced a thinner, less-crusty cold cap. Based on earlier tests at CETL using sodium-bearing waste (SBW) from the Idaho National Environmental Engineering Laboratory (INEEL), it was expected that melt rates could be compared by comparing feed rates (Cozzi et al., 2002). This appears to work reasonably well with the same frit/waste combination (as seen with INEEL SBW and the bubbler) but does not adequately represent melt rate when there is a frit change that significantly alters melting behavior. Glass production is a better measure of melt rate for this situation.

Table 3-9. Frit 320 and Frit 200 Melt Rate Comparison

\begin{tabular}{c|c|c|c|c|c|c}
\hline $\begin{array}{c}\text { Run } \\
\text { date }\end{array}$ & $\begin{array}{c}\text { Feed type } \\
\text { (frit/sludge) }\end{array}$ & $\begin{array}{c}\text { Wt\% } \\
\text { feed } \\
\text { solids }\end{array}$ & $\begin{array}{c}\text { Avg. feed } \\
\text { rate } \\
\text { (g/min) }\end{array}$ & $\begin{array}{c}\text { Avg. glass } \\
\text { pour rate } \\
\text { (g/min) }\end{array}$ & $\begin{array}{c}\text { Vapor space } \\
\text { power } \\
\text { (Btu/min) }\end{array}$ & $\begin{array}{c}\text { Melt pool } \\
\text { power } \\
\text { (Btu/min) }\end{array}$ \\
\hline $7 / 30 / 02$ & $320 /$ SB2 & 40.12 & 42.6 & 13.7 & 124.9 & 53.8 \\
$8 / 07 / 02$ & $200 /$ SB2 & 41.29 & 48.9 & 9.6 & 137.7 & 50.2 \\
\hline
\end{tabular}

\subsubsection{Mini Airlift Bubbler Performance with Frit 320 and Frit 200}

Results from the mini-bubbler tests for Frit 320 and 200 are summarized in Table 3-10. Bubbler tests with these two frits provided additional evidence that differences exist in the behavior of the respective cold caps. For each experiment, the bubbler was positioned about $1 / 4$ " below the glass/cold cap interface. With Frit 320, the bubbler maintained a vent hole throughout the entire test. On occasion the feed covered the vent but within 1 to 2 minutes, the vent re-appeared. The bubbler air was readily vented to the vapor space and no adverse effects on cold cap stability, foam persistence, or entrainment were observed. A $9 \%$ melt rate increase was observed when the mini-bubbler was used with Frit 320. With Frit 200, a cold cap vent hole could not be maintained and a thick, crusty cold cap was formed that grew with processing time. The cold cap trapped the bubbler air, which pressurized the melt pool and significantly increased the pour rate. Therefore, no melt rate determination could be made when the bubbler was used with Frit 200. However, raising the bubbler elevation and discharging in or on-top-of the cold cap may produce more favorable results.

Table 3-10. Bubbler Melt Rate Comparison with Frit 320 and Frit 200

\begin{tabular}{c|c|c|c|c|c}
\hline Run Date & $\begin{array}{c}\text { Feed Type } \\
\text { (frit/sludge) }\end{array}$ & $\begin{array}{c}\text { Wt\% feed } \\
\text { solids }\end{array}$ & $\begin{array}{c}\text { Bubbler } \\
\text { flow rate } \\
\text { (scc/min) }\end{array}$ & $\begin{array}{c}\text { Avg. feed } \\
\text { rate } \\
\text { (g/min) }\end{array}$ & $\begin{array}{c}\text { Avg. glass } \\
\text { pour rate } \\
\text { (g/min) }\end{array}$ \\
\hline $7 / 30 / 02$ & 320 / SB2 & 40.12 & 0 & 42.6 & 13.7 \\
$7 / 31 / 02$ & 320 / SB2 & 40.12 & 35 & 49.2 & 14.9 \\
$8 / 07 / 02$ & 200 / SB2 & 41.29 & 0 & 48.9 & 9.6 \\
$8 / 08 / 02$ & 200 / SB2 & 40.66 & 35 & 50.2 & NA \\
\hline
\end{tabular}

\subsubsection{Frit 200/Frit 320 Cold Cap Comparison}

The observed cold cap characteristics for Frit 200 and Frit 320 in the SMRF were quite different. Both Frit 200 and Frit 320 produced a foam layer, but the nature was different. The Frit 320 foam layer appeared thinner and was somewhat deformable. In contrast, Frit 200 cold cap foam was more rigid, thicker, and appeared to contain a larger void volume. The same observations were noted for the cold caps. Frit 200 produced a harder, thicker cold cap while the Frit 320 cold cap was somewhat softer with a more pliable, thinner understructure. 


\subsubsection{Melter Glass Pool Surface Layer}

When the cold cap for the Frit 320 run burned off, the SMRF melt pool surface had a rough appearance and a few small deposits were visible floating on the surface. After extended idling for $3 \frac{1}{2}$ days the apparent roughness increased as did the floating deposits. These observations were made at a nominal melt pool temperature of $1125^{\circ} \mathrm{C}$ and a vapor space temperature of $750^{\circ} \mathrm{C}$. When the SMRF was drained in preparation for the Frit 200 tests the floating deposits hung on the melter's sidewalls. Samples of this material were collected and submitted for XRD and SEM analyses. Results showed an iron/chrome/nickel spinel as well as rhodium and palladium (see Figure 3-15).

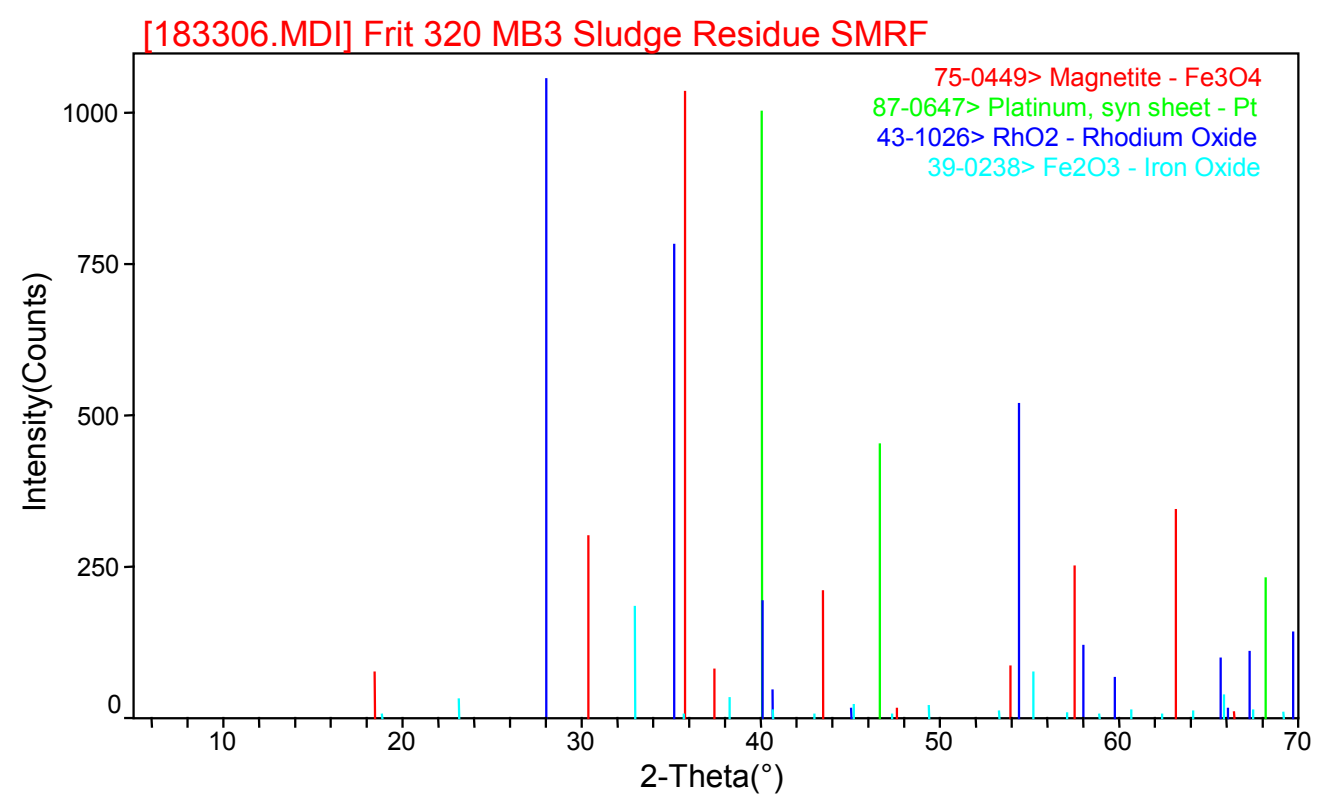

Figure 3-15. XRD Pattern of the Melter Glass Pool Surface Layer of the Frit 320 Tests

The appearance of the Frit 200 melt pool surface was similar but the number of deposits was fewer for any selected time interval. A thick layer ( $\sim 1 / 2$ ") of foam still covered the entire melt pool surface 4 days after Frit 200 slurry feeding was terminated. The vapor space temperature was increased from $750^{\circ} \mathrm{C}$ to $820^{\circ} \mathrm{C}$ in $10^{\circ} \mathrm{C}$ increments to determine the effect on the surface layer thickness. The surface layer thickness decreased to approximately $1 / 16$ " but it did not disappear. The deposits were not sampled and analyzed, but are probably spinels as well.

\subsection{COMPARISON OF MELT RATE EQUIPMENT}

The bulk of the melt rate testing of SB2 in FY02 was conducted with the MRF, but another objective was the development and use of the TLF (dry-feed) and a larger-scale slurry-fed melt rate furnace. The batch size of the dry-feed systems is much smaller than the slurry-fed melter, and tests in the MRF (and the TLF) were much quicker (several tests could be performed each day). The larger-scale slurry-fed system was then utilized to increase confidence in trends observed in the MRF and to ensure that the results are translatable to larger scale slurry-fed melters. The SMRF could run each test for a much longer period of time (several hours) and make better assessments of melting behavior and cold cap behavior.

All melt rate testing of SB2 in the MRF, TLF, and SMRF in FY02 confirmed the melt rate trends shown by previous dry-feed tests and Minimelter tests - the relative melt rate of SB2 with Frit 320 is greater than with Frit 200 (up to $\sim 35 \%$ ). Tests in the SMRF indicate that melt rate may be increased even further with the use of a bubbler - approximate 9\% increase for the SB2/Frit 320 system. Tests in the MRF were beneficial since they were quick indicators of melt rate and melting behavior. Testing in the SMRF then 
confirmed and added to those indicators by advanced assessments of cold-cap behavior, heat transfer improvements with the bubbler, and feed and glass-pour rates. Results obtained with both dry-feed and slurry-feed tests in FY02 have increased the confidence in previous and present tests, and indicate that the results are translatable to larger-scale systems.

\subsection{THERMAL ANALYSIS}

Thermal analysis of all materials tested in the melt rate equipment was performed using a Simultaneous Thermal Analyzer - the STA 409 PC $\operatorname{Luxx}{ }^{\circledR}$. The techniques of differential thermal analysis (DTA) and thermogravimetric analysis (TGA) were utilized to assess the melting processes and pathways of each sample. The objectives of the thermal analysis of tested materials were to determine if large changes in mass result after heating each sample to $1150^{\circ} \mathrm{C}$, and to monitor for temperature regions of transition of each sample (monitor for differences). Also, the amounts of energy required in making transitions were monitored. In DTA, the temperature difference between a reactive sample and a non-reactive reference (in this case the reference was a blank - an empty $\mathrm{Al}_{2} \mathrm{O}_{3}$ crucible) is determined as a function of time, providing useful information about the temperatures, thermodynamics, and kinetics of reactions. The TGA technique determines the weight gain or loss of a condensed phase due to gas release or absorption as a function of temperature.

Each measurement was started with enough material to cover the entire bottom of the sample crucible typically 100-200 milligrams. A dynamic atmosphere of air was utilized, alumina crucibles were used (along with alumina lids), and each run went from room temperature to $1150^{\circ} \mathrm{C}$ at $20^{\circ} \mathrm{C} /$ minute. During the run, a plot of the DTA signal $(\mu \mathrm{V} / \mathrm{mg}$ ) and the TGA signal (weight $\%)$ was generated. These plots are shown in Appendix C.

The plots for the baseline studies show many of the same tendencies. For each frit, there is a large endotherm (DTA signal) at approximately $190^{\circ} \mathrm{C}$, indicating the initial heatup of the sample; then that heat is liberated until $\sim 850^{\circ} \mathrm{C}$. This indicates that the samples are transitioning (melting) at the same temperature and requiring approximately the same amount of energy. Also, the TGA signals all arrive near the same endpoint (87.8-90.3\%), which is expected since the only difference between these samples was the frit (no difference in WL, etc.).

Thermal analysis results for the higher waste-loading tests were very consistent, as expected since the only variable was waste loading. The endpoint of the TGA signal ranged from $\sim 89.5 \%$ for the $27 \%$ WL case to $\sim 84.5 \%$ for the $37 \%$ WL case. Less frit is present at higher waste loadings, so fewer solids will remain at the end of the experiment, resulting in a slightly less weight $\%$ remaining. The DTA signals show the same trends as well. The same shape of the curves resulted for each waste loading with slightly more energy required to melt the waste loadings of $33-41 \%$. This is a result of less frit being present as well. Each peak in energy occurred at approximately $880^{\circ} \mathrm{C}$, which indicates the transition point (point at which the batch approaches the molten state) of each sample.

Even though there was very little difference in melt rate shown for the frit particle-size tests, there was a difference in the energy curves for the separate particle sizes. The trends were the same for both signals for each frit, but different peaks and endpoints resulted. The DTA signal for the Frit 320 Unders peaked higher $(\sim 0.0 \mu \mathrm{V} / \mathrm{mg})$ on its return to baseline than the run with Frit 320 Overs. The Frit 320 Overs was not as great since less material was present at the peak temperature $\left(\sim 890^{\circ} \mathrm{C}\right)$, which is evident by the TGA signal of each plot. Though the shapes of the curves are the same, indicating the same transition temperatures, $\sim 90.6 \%$ weight remained for the Frit 320 Unders versus only $80 \%$ for the Frit 320 Overs. This could be attributed to more sludge being able to sorb to the frit because of the greater surface area of the Frit 320 Unders (resulting in more solids and mass remaining), or to mixing and/or sampling errors. Finally, in comparing these particle-size tests of Frit 320 with the baseline $(-80,+200$ mesh size), the DTA signal of the baseline run peaks at $\sim-0.04 \mu \mathrm{V} / \mathrm{mg}$ on its return to equilibrium, which is in the middle of the peaks of the alternate frit sizes. 
The thermal analysis studies were very useful in determining the amount of weight loss of each tested material and the amount of energy required when going through transition temperatures. Trends of these thermal analyses indicate that more energy is required (larger peaks in the DTA signal) when less frit and less alkali is present in the batch (higher waste loading and spiked-sodium tests, respectively). Also, more energy was required in melting the 320 Overs material. The weight loss trends (TGA) indicate that a greater weight loss is experienced with higher waste loadings and with a larger frit particle size. The thermal analyzer can be used to find energy and weight loss data for materials, but it should not be used as the only tool in determining melt rate.

\subsection{URANIUM STUDIES}

The melt rate testing performed in FY01 and FY02 used non-uranium-containing sludge. The composition of SB2 was originally given with a $9.94 \mathrm{wt} \% \mathrm{U}_{3} \mathrm{O}_{8}$ (nominal) (Peeler et. al, 2001), but in order to allow testing to proceed under non-radioactive conditions, the uranium was removed and all other oxides were renormalized to provide a relative measure of melt rate. To lower the risk that the presence of uranium in the sludge did not have a significant impact on melt rate, a suite of crucible-scale tests was performed with Frit 200 and 320 and adding uranium (enough to total $9.94 \mathrm{wt} \%$ in the sludge) to the batch. Since these crucibles could not be sectioned to determine semi-quantitative melt rates, the original batch height was marked on the outside of the crucible and visual observations of the inner sides for any advances in batch height during the two-hour residence time in the furnace were made. As shown by Figure 3-16, there was little evidence, if any, of batch expansion or foaming during melting. The dark areas on the side above the glass indicate the original batch height. When compared to those tests in which uranium was absent, no significant differences are observed. These results suggest that this amount of uranium has no adverse effects on melting behavior or melt rate of SB2 with Frits 200 and 320, assuming scale-up is similar to what has previously been observed.

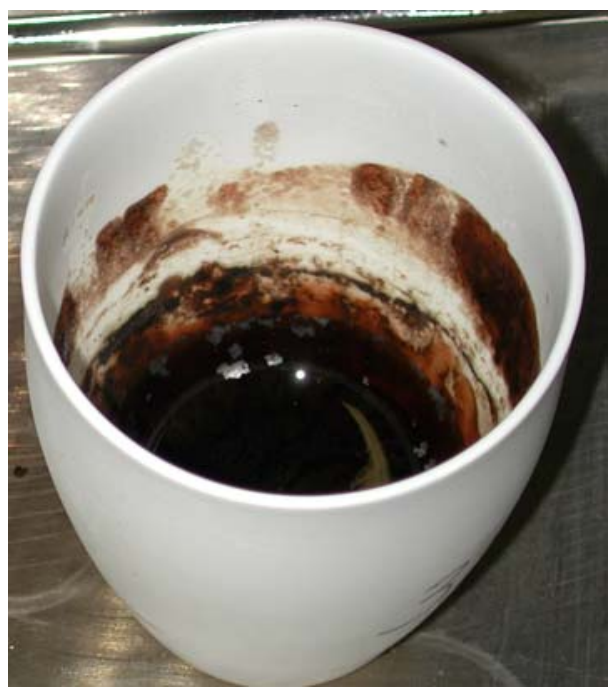

Frit 320 test with uranium

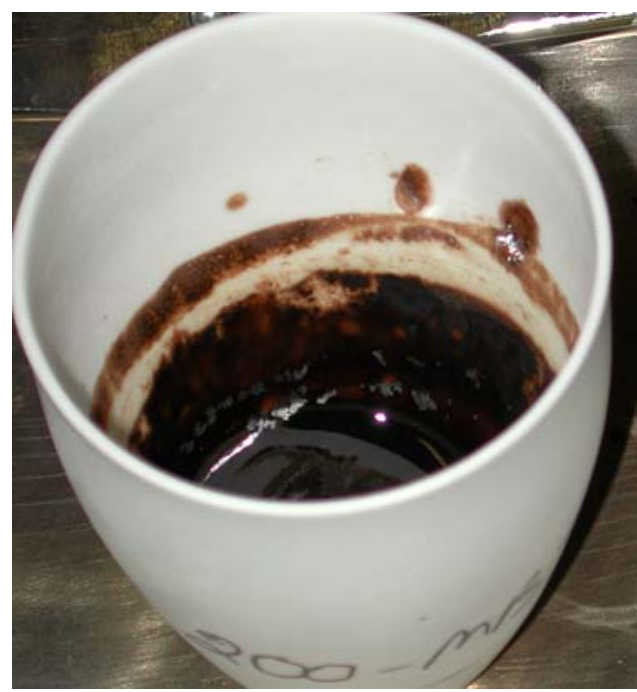

Frit 200 test with uranium 


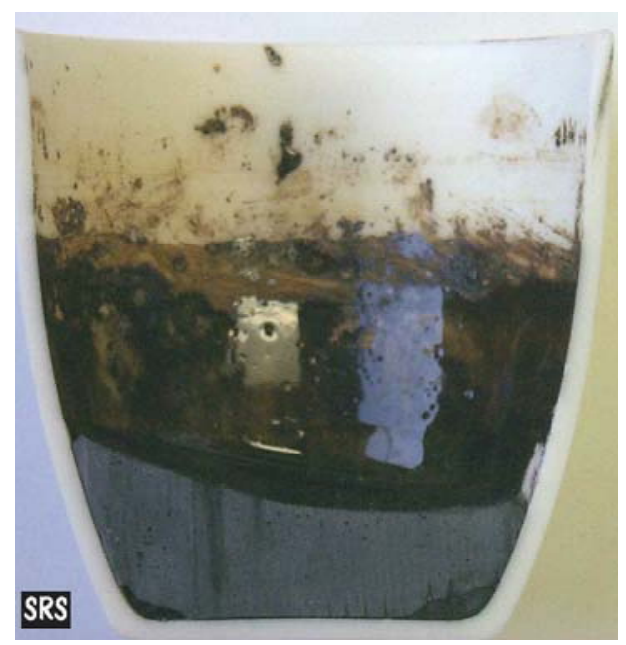

Frit 320 test without uranium

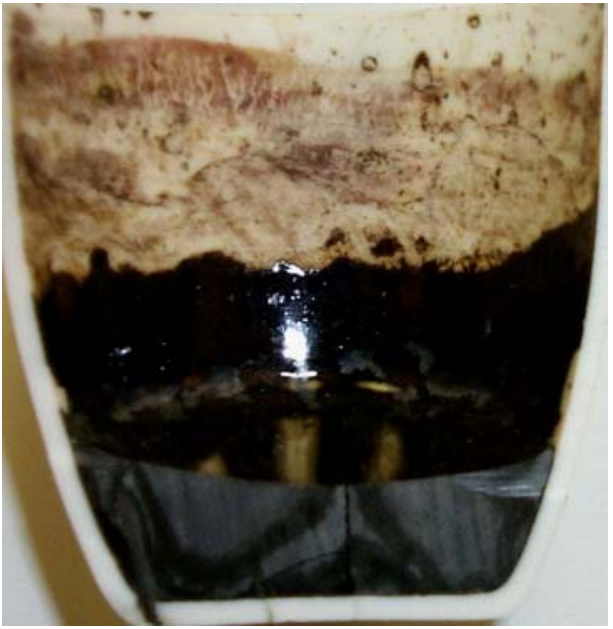

Frit 200 test without uranium

Figure 3-16. Fired crucibles from the assessment of melt rate and batch expansion (foaming) of SB2 with Frits 200 and 320, with and without uranium.

\subsection{CONCLUSIONS/SUMMARY}

Results obtained with the MRF for the baseline tests showed the same trends observed during FY01 testing - Frit 320 melts faster than Frit 200 at a fixed waste loading for SB2. However, it was found that the Purex sludge did not melt as consistently nor as well as the SB2 SRAT product.

Waste loadings for the higher waste-loading tests ranged from $27 \%$ to $41 \%$, and all utilized Frit 320 and simulated SB2 SRAT product. The $41 \% \mathrm{WL}$ bounds projected maximum waste loadings based on implementation of the new $T_{L}$ model. The results and trends of these scoping studies indicate that within the WL range tested, melt rate decreases as WL increases (see Table 3-2 and Figure 3-1). However, the net effect is that the amount of waste processed per hour (throughput) increases relative to the $25 \% \mathrm{WL}$ baseline up to 35\% WL, based on the linear melt rate data (see Table 3-3 and Figure 4-1). Operation beyond 38\% WL may not be advantageous unless the cost savings associated with the reduced number of canisters outweighed the throughput reduction. Melting behavior would also need to be investigated to assess its impact.

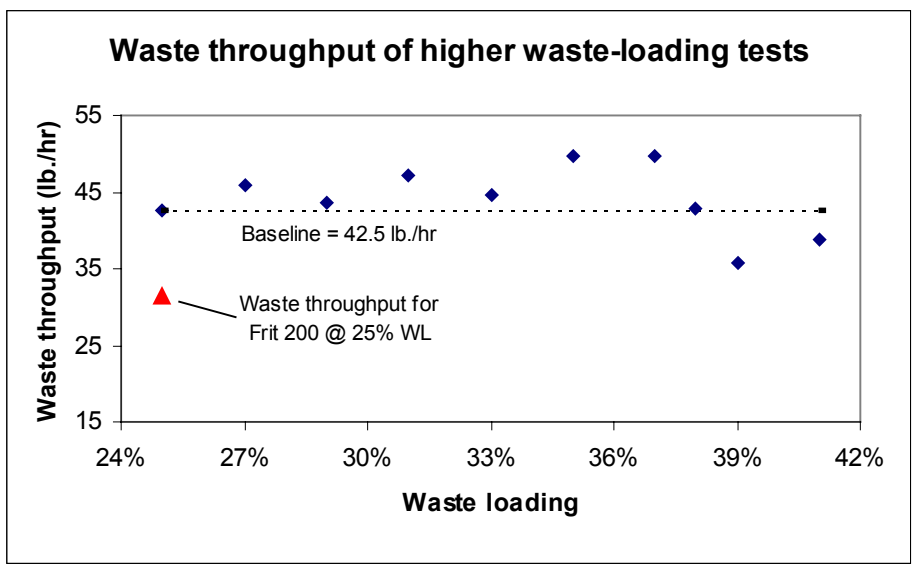

Figure 4-1. Plot of Waste Throughput for Frit 320 with SB2 as a Function of Waste Loading (Data from Table 3-3). 
No significant melt-rate improvements were identified by using batch chemicals instead of a frit, or by switching to a finer or larger frit particle-size than the standard currently being used. In the MRF (a dryfeed system), significant batch expansion was observed with the use of batch chemicals. It was also believed that changing to a finer or larger particle-size frit might enhance melt rate as well. However, the Frit 320 Unders melted at almost the same rate as the $-80,+200$ mesh-sized frit ( 0.98 and $1.04 \mathrm{in.} / \mathrm{hr}$. , respectively), while the Frit 320 Overs melted more slowly (0.79 in./hr.).

The SMRF tests indicated that the Frit 320/SB2 system melts $\sim 35 \%$ faster than Frit 200/SB2. The difference in melt rate was contributed to major differences in the melting and cold cap behaviors. The Frit 200 cold cap was very rigid, appeared thicker, and appeared to contain a large void volume. The cold cap observed with Frit 320 appeared thinner and was somewhat deformable. Both cold caps contained a significant amount of foam. The increased melt rate based solely on a frit change (at constant WL) is consistent with the initial crucible-scale and MRF tests and the 786-A Mini-melter demonstration. This gives a higher level of confidence that the implementation of Frit 320 in DWPF should result in an enhanced melt rate or higher waste throughput.

Based on previous SMRF tests, it was expected that melt rates could be compared by the feed rates. This appears to work reasonably well with the same frit/waste combination but does not adequately represent melt rate when there is a frit change that significantly alters melting behavior. Glass production is a better measure of melt rate for this situation. Slurry-fed tests with the bubbler indicate that melt rate can be enhanced with greater heat transfer to the cold cap region. A melt rate increase of almost $9 \%$ was observed when the mini-bubbler was used with Frit 320/SB2. Also, it was observed that a bubbler flow rate of approximately $15 \mathrm{scc} /$ minute was suitable for pulling molten glass toward the cold cap region of the melt pool.

The results indicate that the SMRF is a valuable tool for the determination of melting behavior and melt rate for various frit / sludge combinations. This is a tool that should be integrated into the development of an integrated flowsheet as various frit / sludge combinations are considered or alternative processing strategies are assessed.

\subsection{FUTURE/ONGOING WORK}

Assessments of melting behavior and melt rate need to made on all current and future sludge batches processed in the DWPF in an effort to maximize waste throughput and canister production. With the appearance that higher waste throughputs of SB2/Frit 320 can be achieved with higher waste loadings, it is recommended that tests in the SMRF be completed at higher waste loadings $(25-38 \% \mathrm{WL})$ in order to assess melting and cold cap behavior.

Melt rate testing to date with SB2 has indicated a correlation between alkali content of the feed and melt rate. The additional alkali can either be added to the process frit or added to the sludge (less sludge washing) during processing to produce melter feed. The impact of adding alkali to the process frit was tested during FY01 and led to the recommendation that Frit 320 be utilized for SB2. Melt rate improvement may be increased if the additional alkali is added to the sludge instead of the frit. If melt rate can be enhanced via this method, fewer sludge washings would be required - saving time, money, and tank space. Initial tests of this scenario (SRAT products simulated to different number of washings) are currently being conducted for the processing of sludge batch 3 (SB3) in the MRF.

Finally, frit development is performed for specific sludge batches and waste loadings. A frit designed for one sludge batch may not be the most suitable for future sludge batches. The development of different frits targeting specific waste loadings should be completed for each sludge batch. Frit development is currently being performed for SB3 as well. 
Immobilization Technology Section

WSRC-TR-2002-00545

Savannah River Technology Center

Westinghouse Savannah River Company

\subsection{REFERENCES}

Brown, K.G., C.M. Jantzen, and G. Ritzhaupt. 2001. Relating Liquidus Temperature to Composition for the Defense Waste Processing Facility (DWPF) Process Control, WSRC-TR-2001-00520, Westinghouse Savannah River Company, Aiken, SC.

Cozzi, A.D., D.F. Bickford, and M.E. Stone. 2002. Slurry Fed Melt Rate Furnace Runs to Support Glass Formulation Development for INEEL Sodium-Bearing Waste, WSRC-TR-2002-00192, Westinghouse

Savannah River Company, Aiken, SC.

Jones, T., T.H. Lorier, and D.C. Witt. 2002. Run Plan for Frit 200 and SB2 Sludge in the Slurry-fed Melt Rate Furnace, SRT-GPD-2002-00080, Westinghouse Savannah River Company, Aiken, SC.

Jones, T., T.H. Lorier, and D.C. Witt. 2002. Run Plan for Frit 200 and SB2 Sludge in the Slurry Fed Melt Rate Furnace, SRT-GPD-2002-00085, Westinghouse Savannah River Company, Aiken, SC.

Jones, T., T.H. Lorier, and D.C. Witt. 2002. Run Plan for Frit 320 and SB2 Sludge in the Slurry Fed Melt Rate Furnace, SRT-GPD-2002-00084, Westinghouse Savannah River Company, Aiken, SC.

Jones, T., T.H. Lorier, and D.C. Witt. 2002. Run Plan \#2 for Frit 320 and SB2 Sludge in the Slurry Fed Melt Rate Furnace, SRT-GPD-2002-00102, Westinghouse Savannah River Company, Aiken, SC.

Jones, T., T.H. Lorier, and D.C. Witt. 2002. $2^{\text {nd }}$ Run Plan for Frit 200 and SB2 Sludge in the Slurry Fed Melt Rate Furnace, SRT-GPD-2002-00098, Westinghouse Savannah River Company, Aiken, SC.

Jones, T., T.H. Lorier, and D.C. Witt. 2002. Run Plan \#3 for Frit 200 and SB2 Sludge in the Slurry Fed Melt Rate Furnace, SRT-GPD-2002-00103, Westinghouse Savannah River Company, Aiken, SC.

Lambert, D.P., T.H. Lorier, D.K. Peeler, and M.E. Stone. 2001. Melt Rate Improvement for DWPF MB3: Summary and Recommendations (U), WSRC-TR-2001-00148, Westinghouse Savannah River Company, Aiken, SC.

Miller, D.H. 2002. Summary of Results from Minimelter Run with Macrobatch 3 Baseline Feed Using Frit 320 (U), WSRC-TR-2002-00188, Westinghouse Savannah River Company, Aiken, SC.

Peeler, D.K., T.H. Lorier, D.F. Bickford, D.C. Witt, T.B. Edwards, K.G. Brown, I.A. Reamer, R.J. Workman, and J.D. Vienna. 2001. Melt Rate Improvement for DWPF MB3: Frit Development and Model Assessment (U), WSRC-TR-2001-00131, Westinghouse Savannah River Company, Aiken, SC.

Stone, M.E., and J.E. Josephs. 2001. Melt Rate Improvement for DWPF MB3: Melt Rate Furnace Testing (U), WSRC-TR-2001-00146, Westinghouse Savannah River Company, Aiken, SC.

Stone, M.E., and D.P. Lambert. 2001. Melt Rate Improvement for MB3: Feed Preparation, WSRC-TR2001-00126, Westinghouse Savannah River Company, Aiken, SC.

Westinghouse Savannah River Company (WSRC). 2001. Savannah River Site High Level Waste System Plan (HLW), HLW-2001-00040, Revision 12. Aiken, SC. 
Immobilization Technology Section

Savannah River Technology Center

Westinghouse Savannah River Company

\section{APPENDIX A}

A1: Sectioned Beakers of the Baseline Tests in the MRF A2: Sectioned Beakers of the Higher Waste Loading Tests in the MRF 
Immobilization Technology Section

Savannah River Technology Center

Westinghouse Savannah River Company

A1. Sectioned Beakers of the Baseline Tests in the MRF
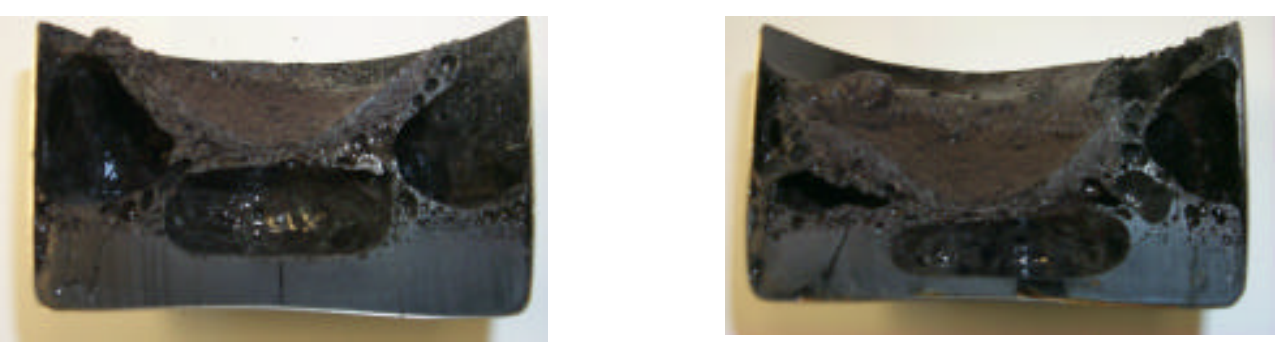

Frit 200 + Purex (Runs \#1 and \#2)
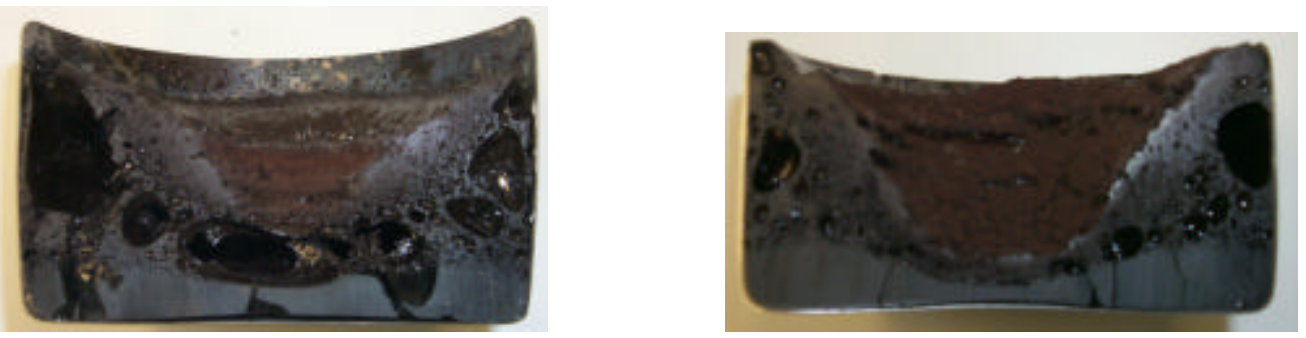

Frit $200+$ SB2 (Runs \#1 and \#2)
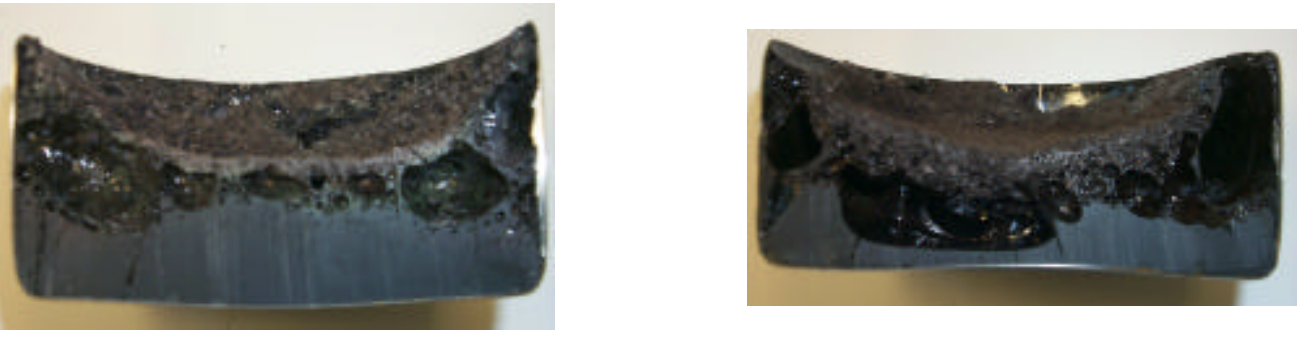

Frit 320 + Purex (Runs \#1 and \#2)

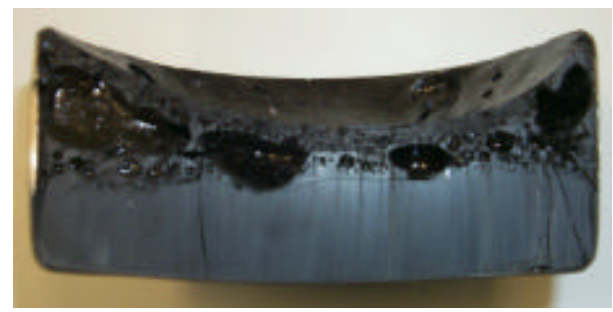

Frit $320+$ SB2 
A2. Sectioned Beakers of the Higher Waste Loading Tests in the MRF

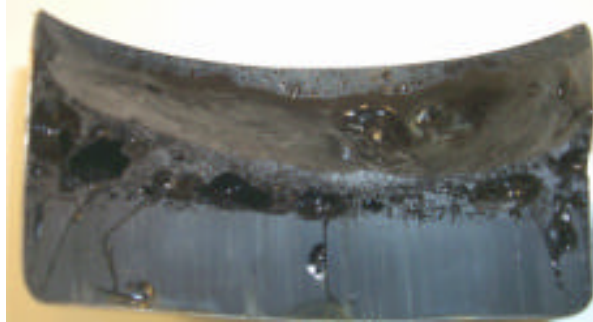

$27 \% \mathrm{WL}$

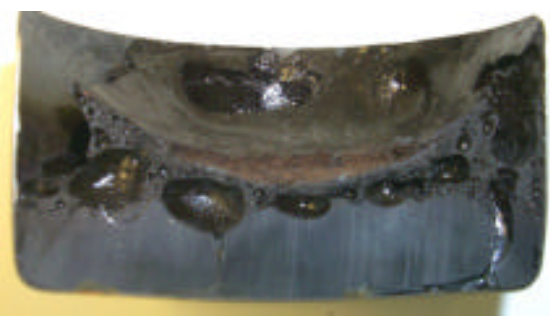

$31 \% \mathrm{WL}$

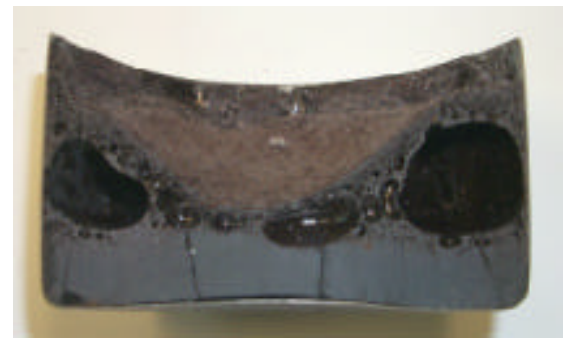

$33 \% \mathrm{WL}$ (run \#2)

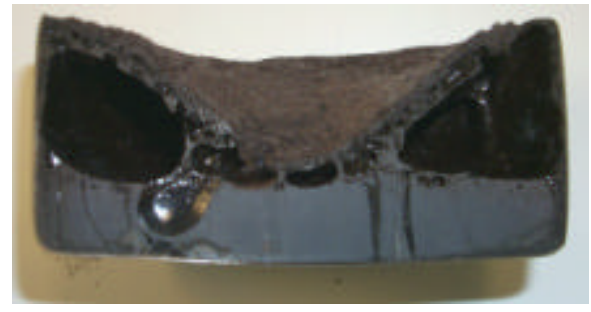

$35 \% \mathrm{WL}$ (run\#2)

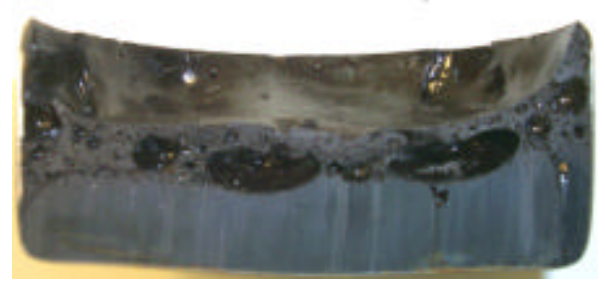

$29 \% \mathrm{WL}$
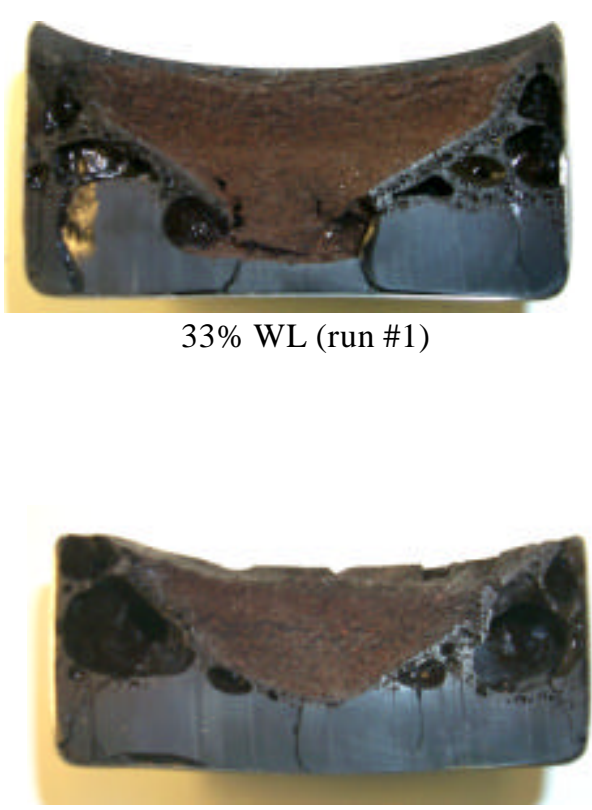

$35 \%$ WL (run \#1)

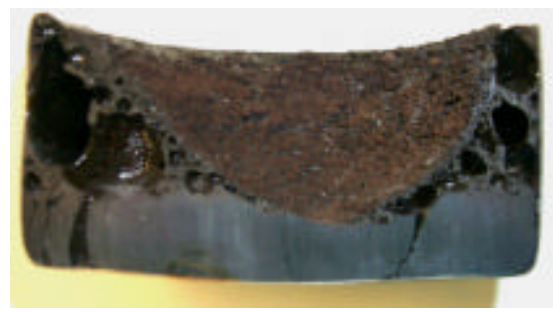

$37 \% \mathrm{WL}$ 
Immobilization Technology Section

Savannah River Technology Center

Westinghouse Savannah River Company

A2. (cont'd)

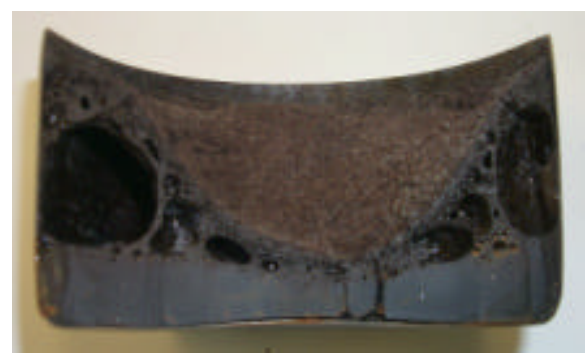

$38 \% \mathrm{WL}$

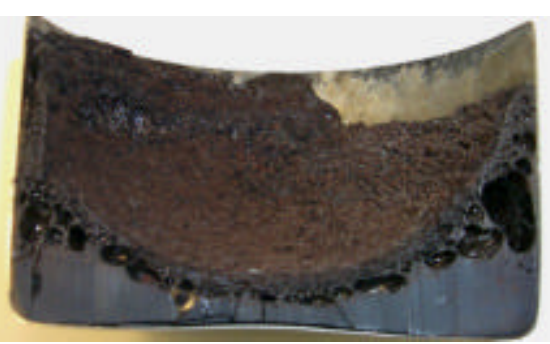

$39 \% \mathrm{WL}$

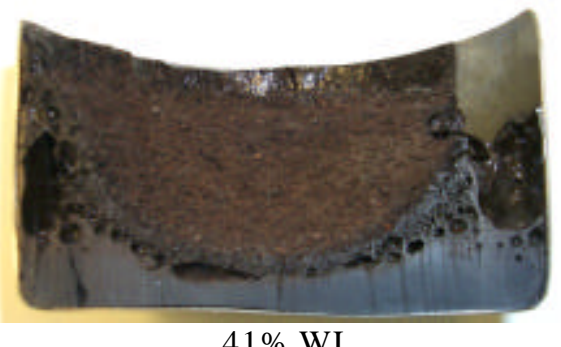

$41 \% \mathrm{WL}$ 
Immobilization Technology Section

Savannah River Technology Center

Westinghouse Savannah River Company

A4. Sectioned Beakers of the Frit Particle-size Tests

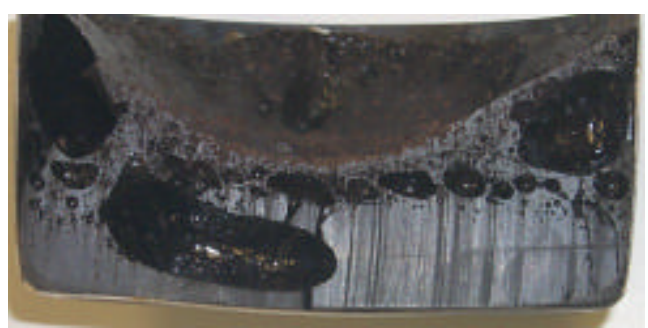

Frit 320 Overs

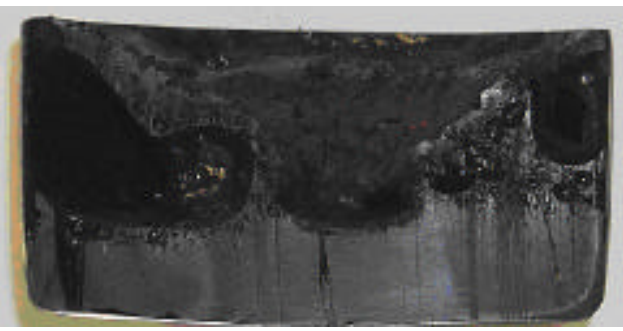

Frit 320 Unders 
Immobilization Technology Section

Savannah River Technology Center

Westinghouse Savannah River Company

\section{APPENDIX B}

B1: Temperature Profiles of the Baseline Tests in the MRF

B2: Temperature Profiles of the Higher Waste Loading Tests in the MRF

B3: Temperature Profiles of the Frit Particle-size Tests in the MRF 
Immobilization Technology Section

WSRC-TR-2002-00545

Savannah River Technology Center

Westinghouse Savannah River Company

B1. Temperature Profiles of the Baseline Tests in the MRF
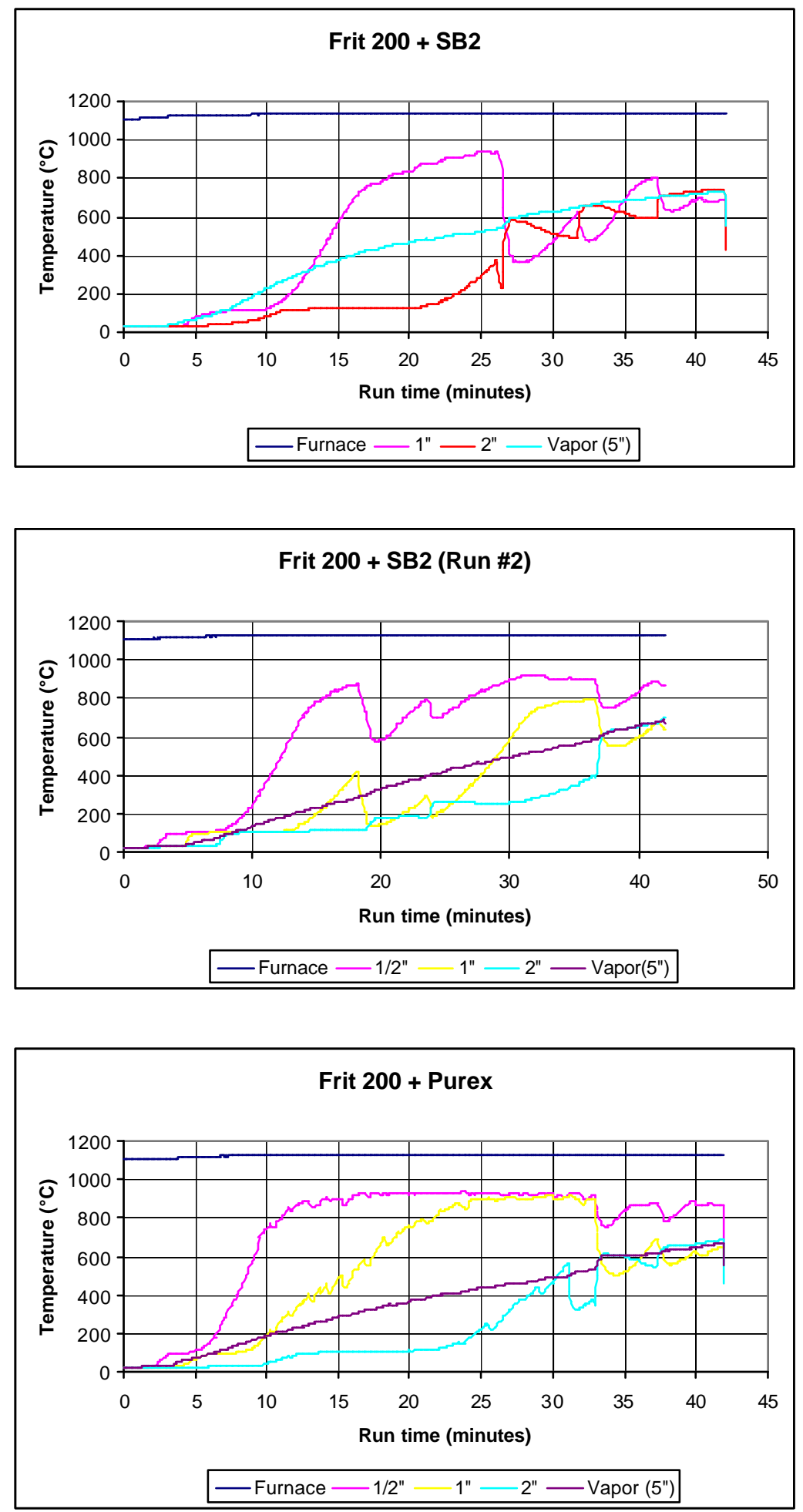
Immobilization Technology Section

WSRC-TR-2002-00545

Savannah River Technology Center

Westinghouse Savannah River Company

B1 (cont'd)
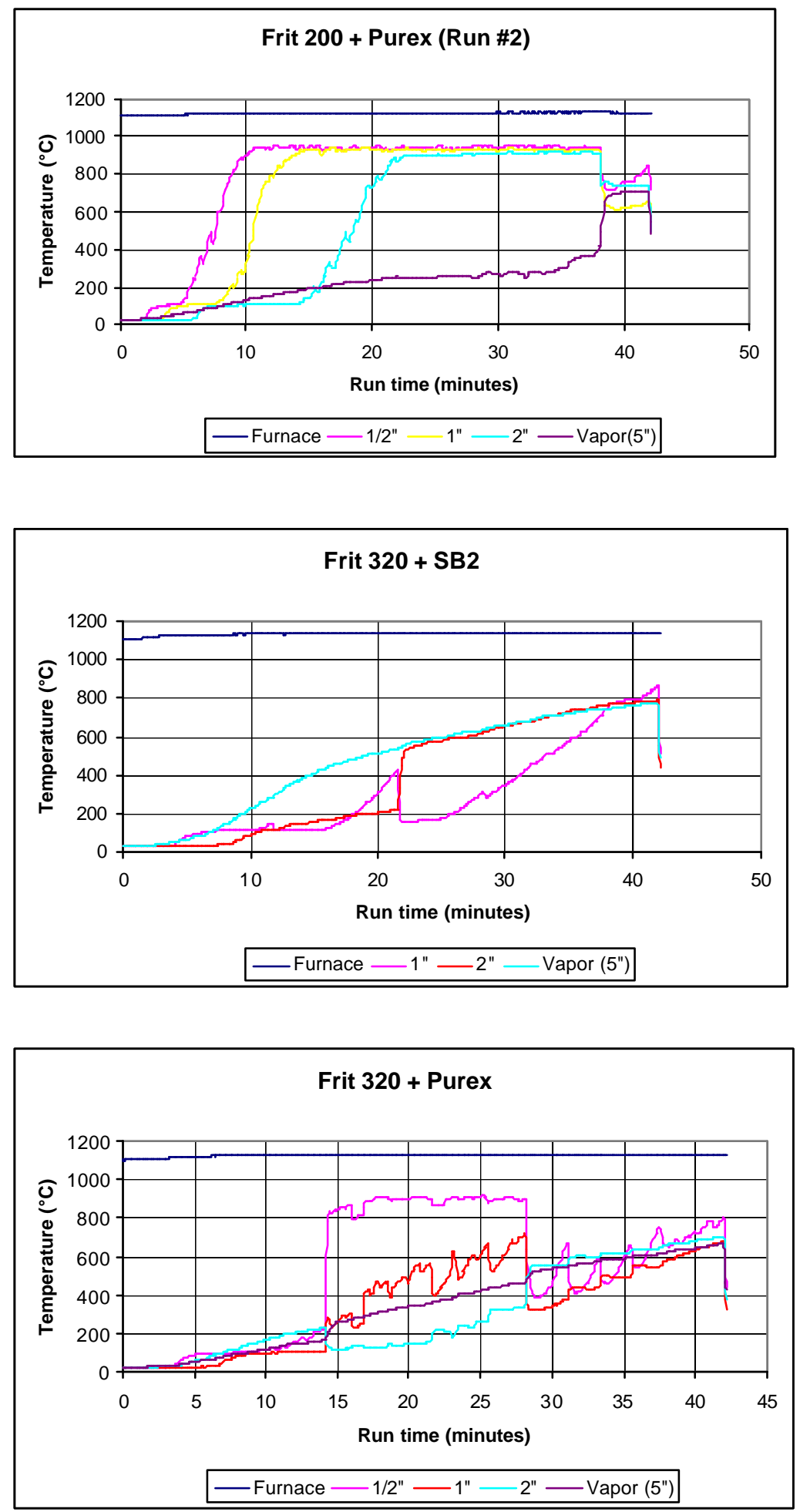
Immobilization Technology Section

Savannah River Technology Center

Westinghouse Savannah River Company

B1 (cont'd)

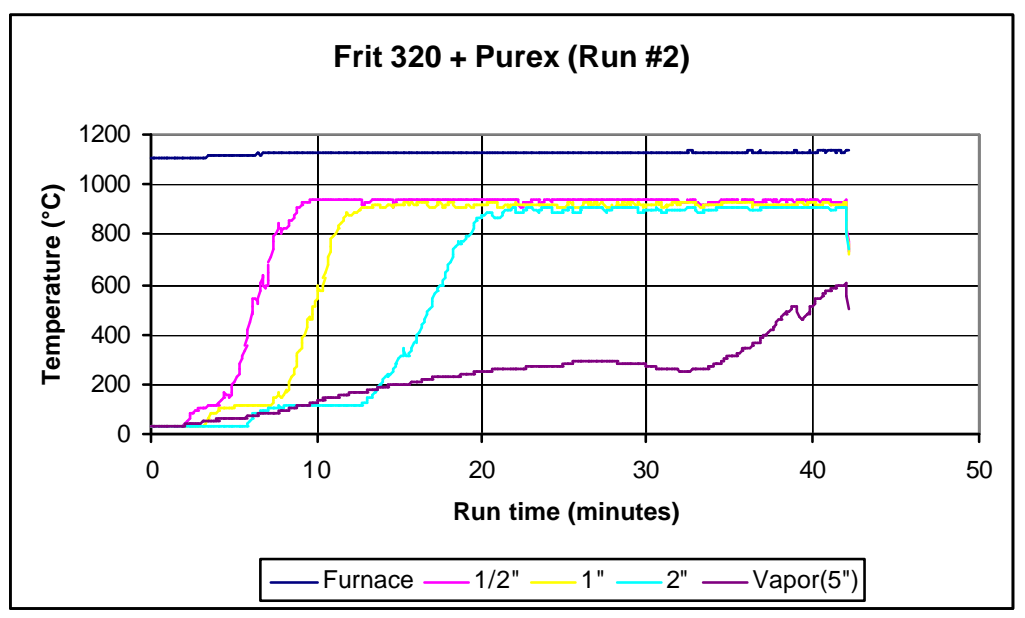


Immobilization Technology Section

WSRC-TR-2002-00545

Savannah River Technology Center

Westinghouse Savannah River Company

B2. Temperature Profiles of the Higher Waste Loading Tests in the MRF
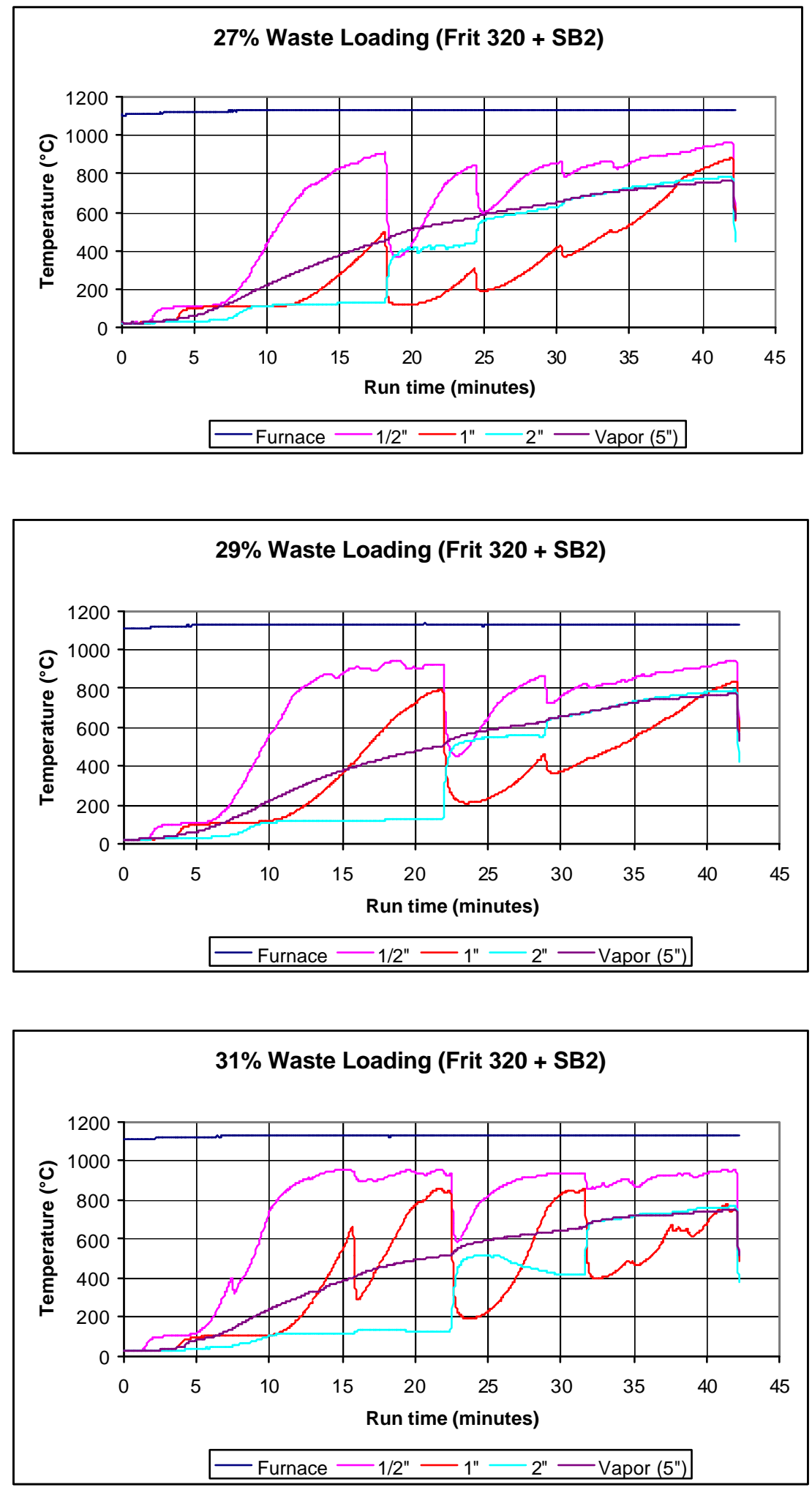
Immobilization Technology Section

WSRC-TR-2002-00545

Savannah River Technology Center

Westinghouse Savannah River Company

B2 (cont'd)
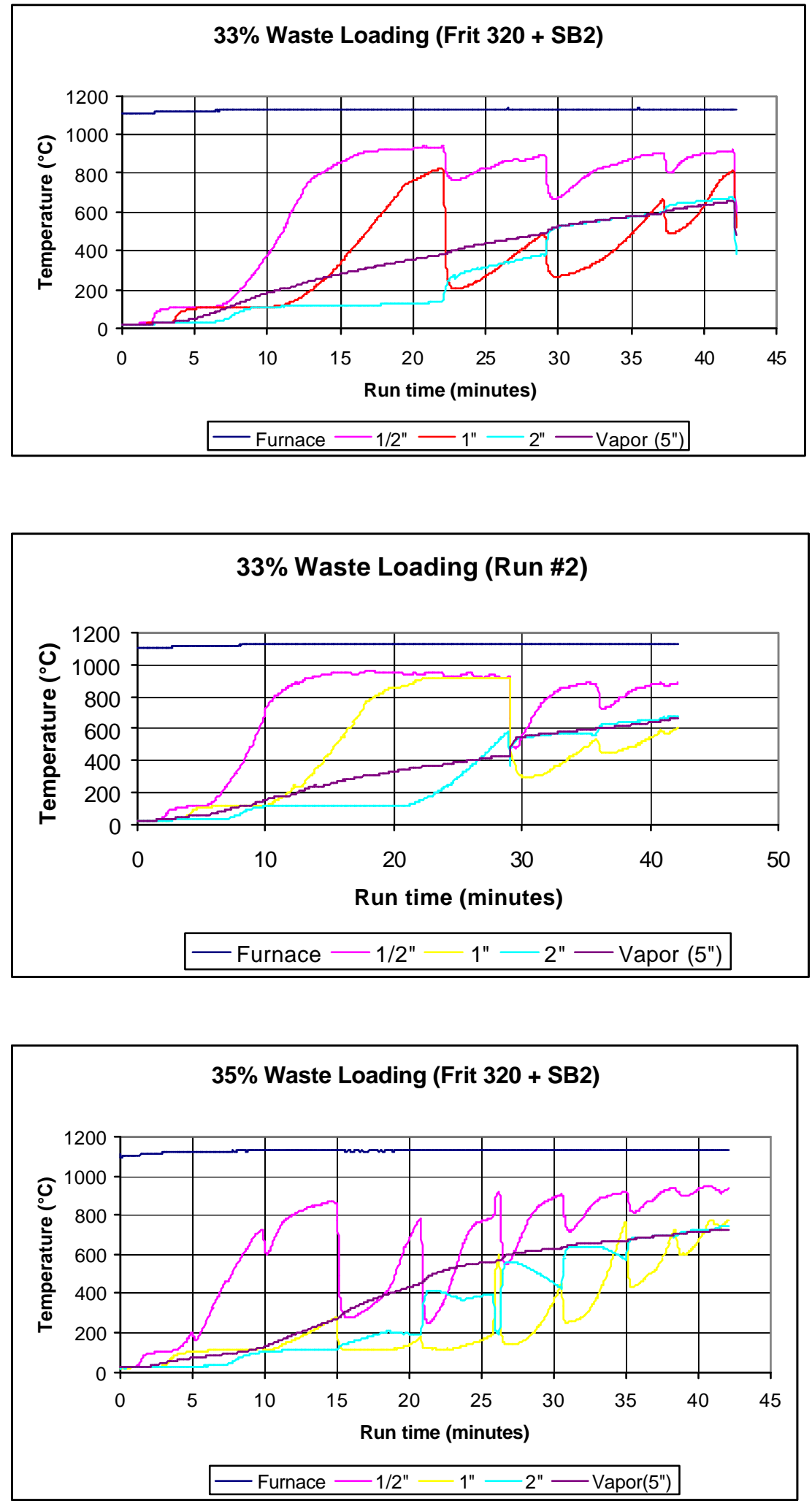
Immobilization Technology Section

Savannah River Technology Center

Westinghouse Savannah River Company

B2 (cont'd)
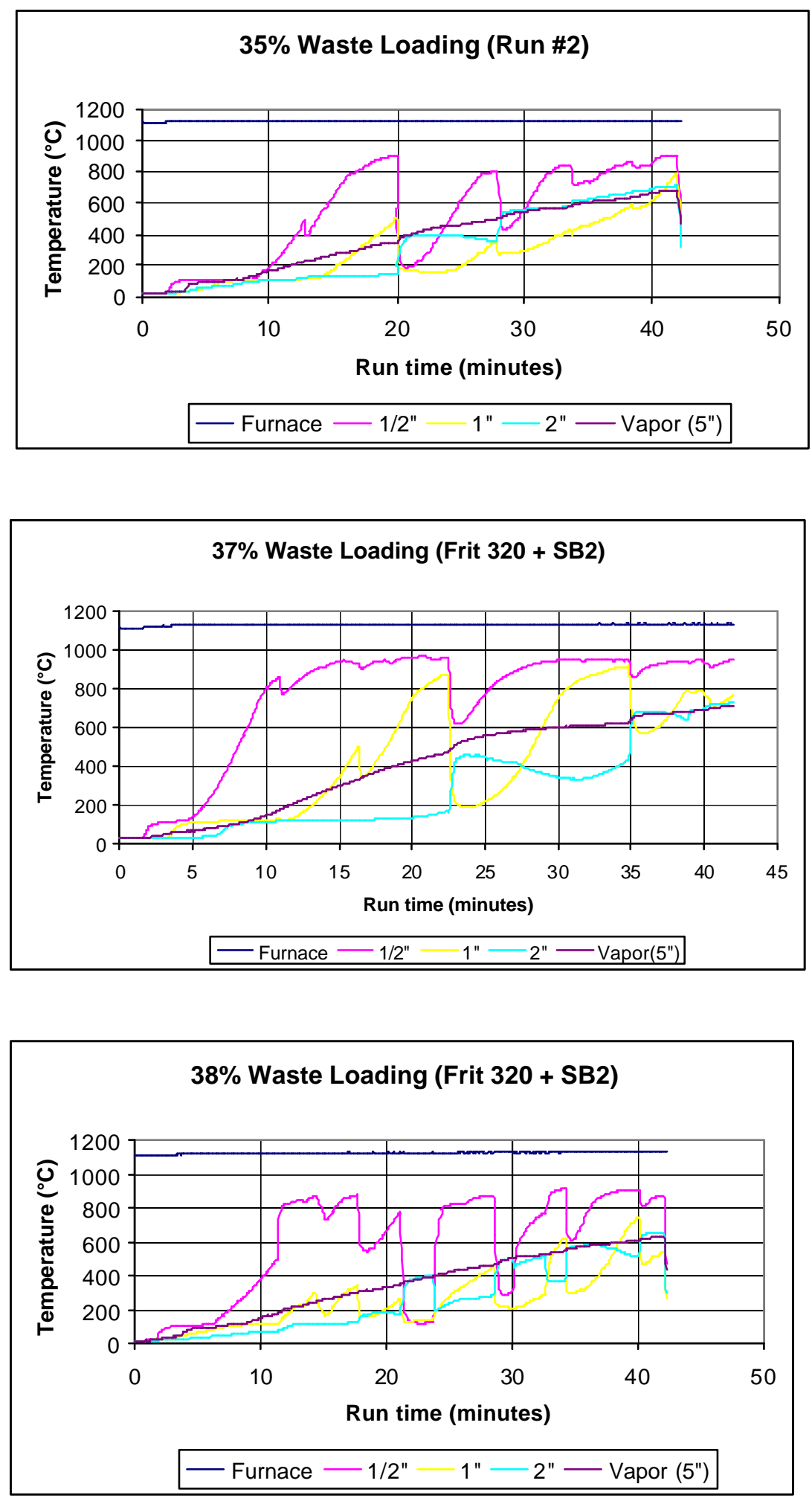
Immobilization Technology Section

Savannah River Technology Center

Westinghouse Savannah River Company

B2 (cont'd)
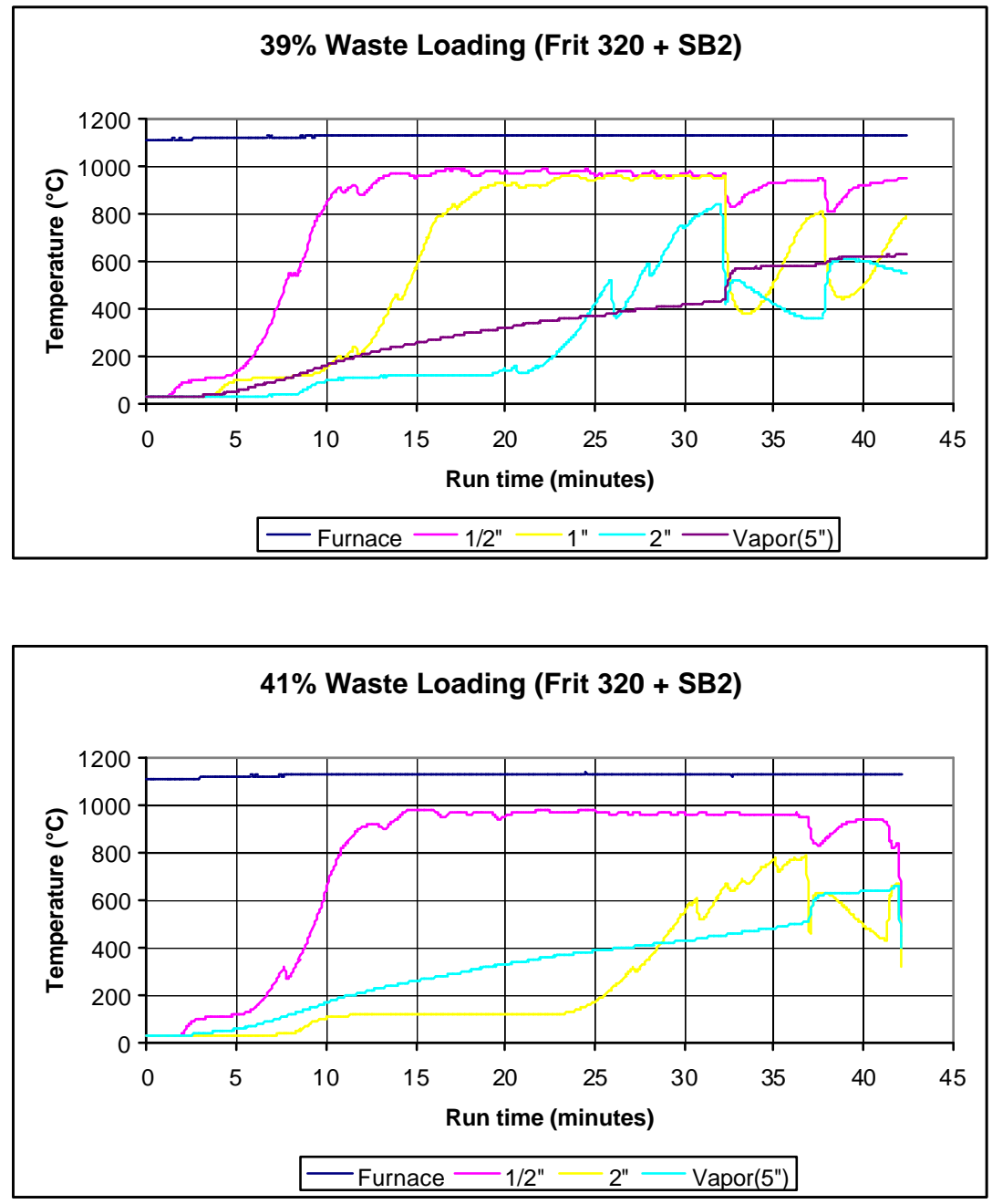
Immobilization Technology Section

Savannah River Technology Center

Westinghouse Savannah River Company

B3. Temperature Profiles of the Frit Particle-size Tests in the MRF
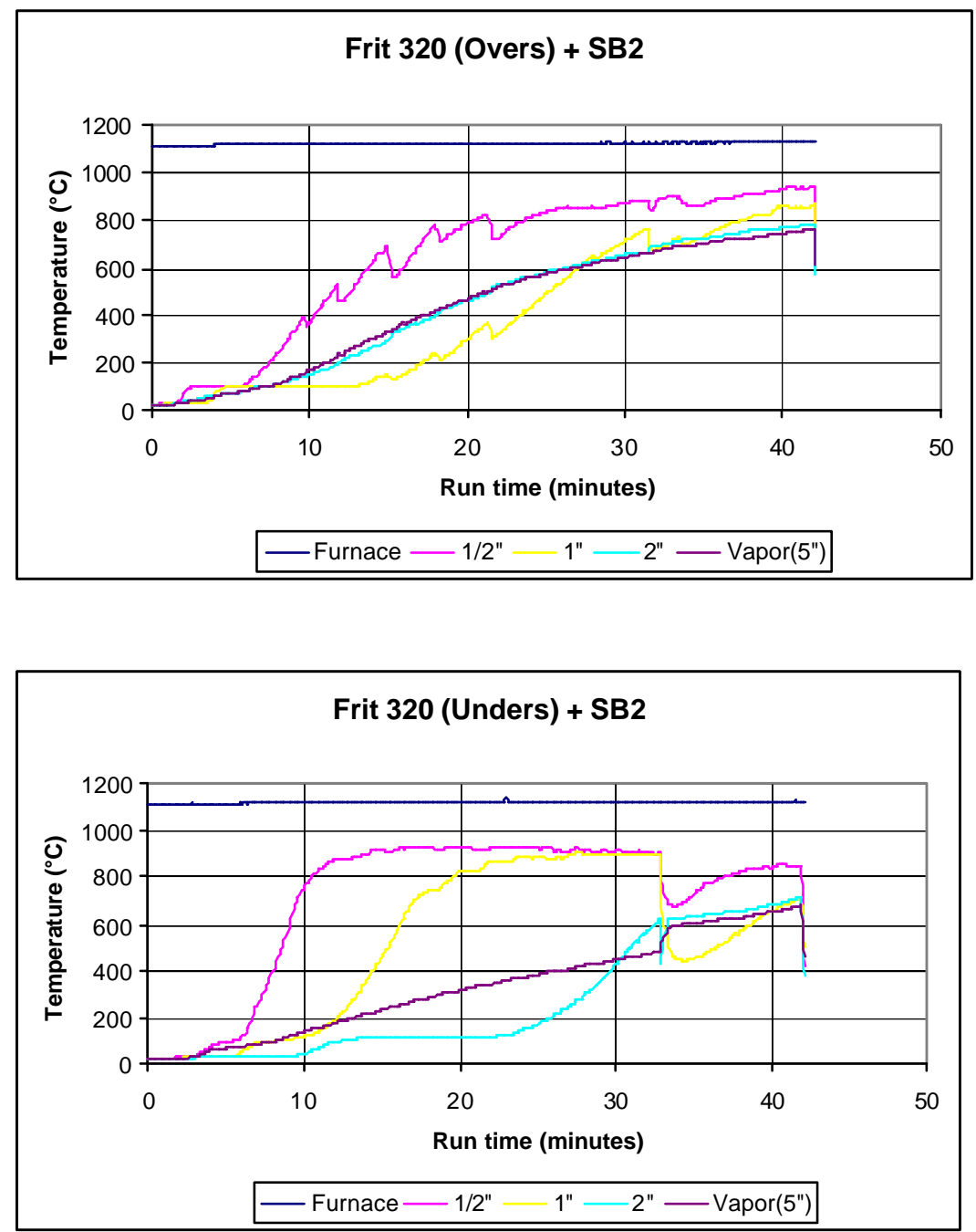
Immobilization Technology Section

Savannah River Technology Center

Westinghouse Savannah River Company

\section{APPENDIX C}

C1: Thermal Analysis Plots for the Baseline Tests in the MRF

C2: Thermal Analysis Plots for the Higher Waste Loading Tests in the MRF

C3: Thermal Analysis Plots for the Frit Particle-size Tests in the MRF 
Immobilization Technology Section

Savannah River Technology Center

Westinghouse Savannah River Company

C1. Thermal Analysis Plots for the Baseline Tests in the MRF

Frit $200+$ Purex

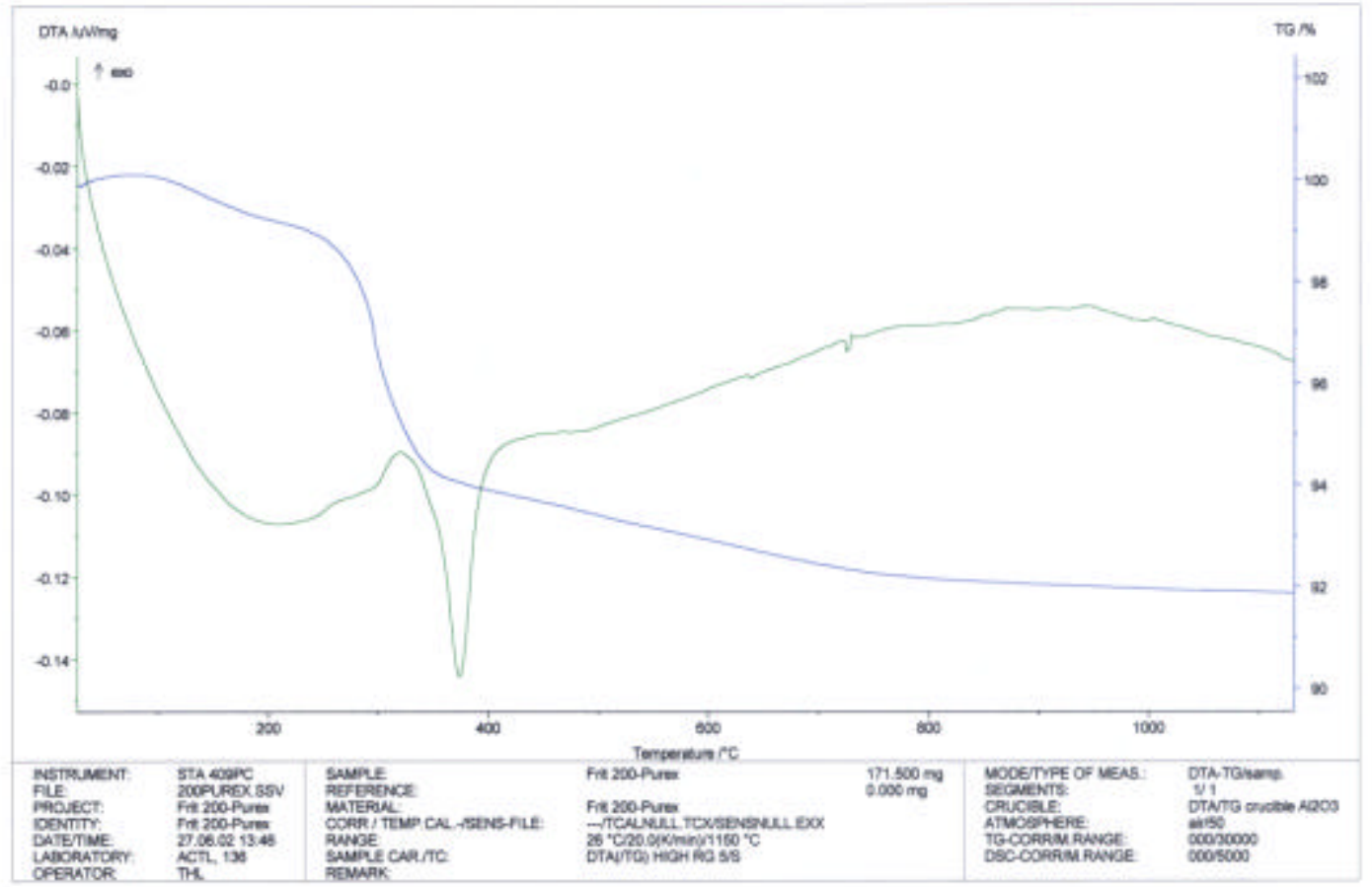

Frit $200+S B 2$

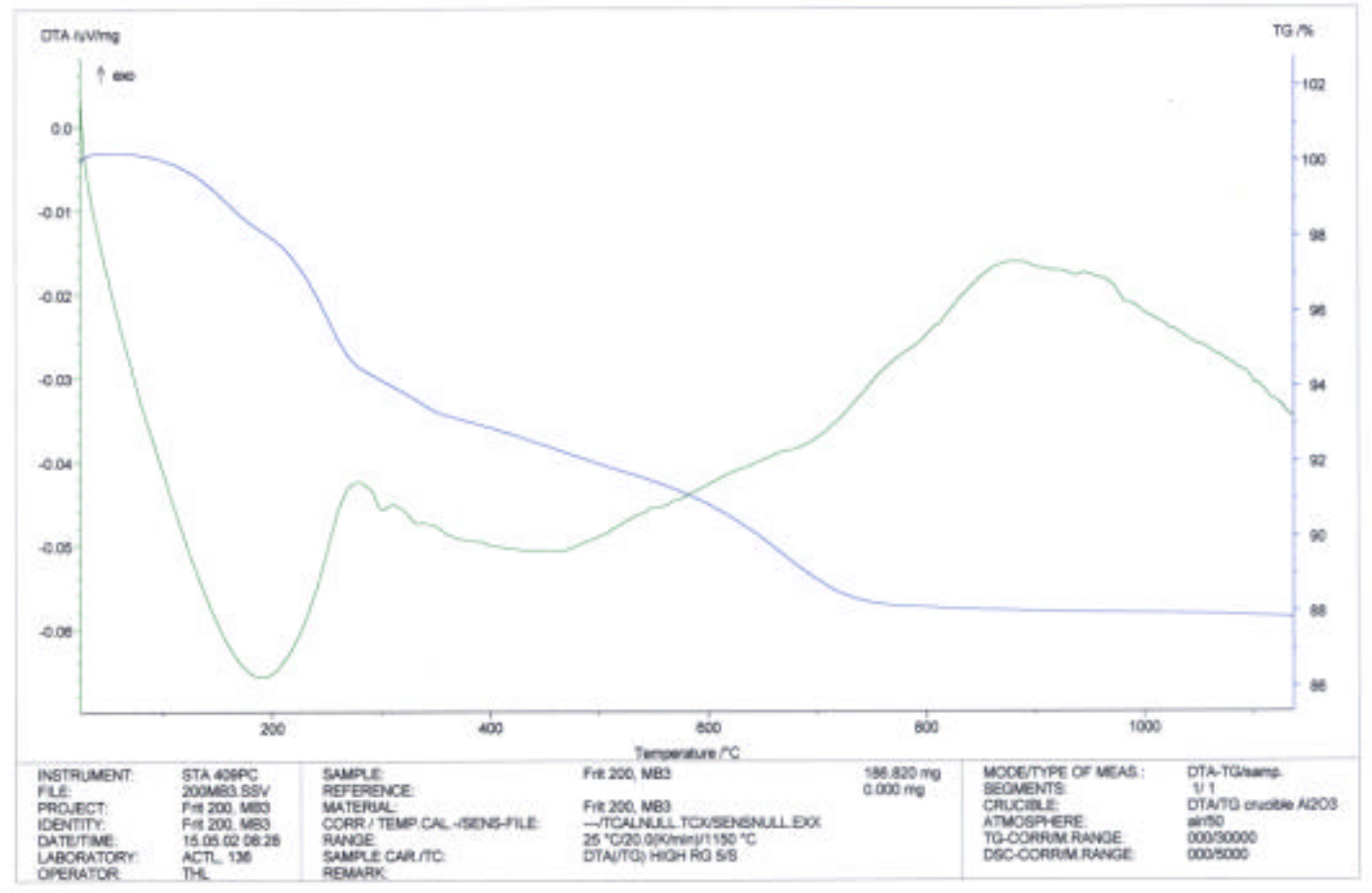


Immobilization Technology Section

Savannah River Technology Center

Westinghouse Savannah River Company

C1. (cont'd)

Frit $320+$ Purex

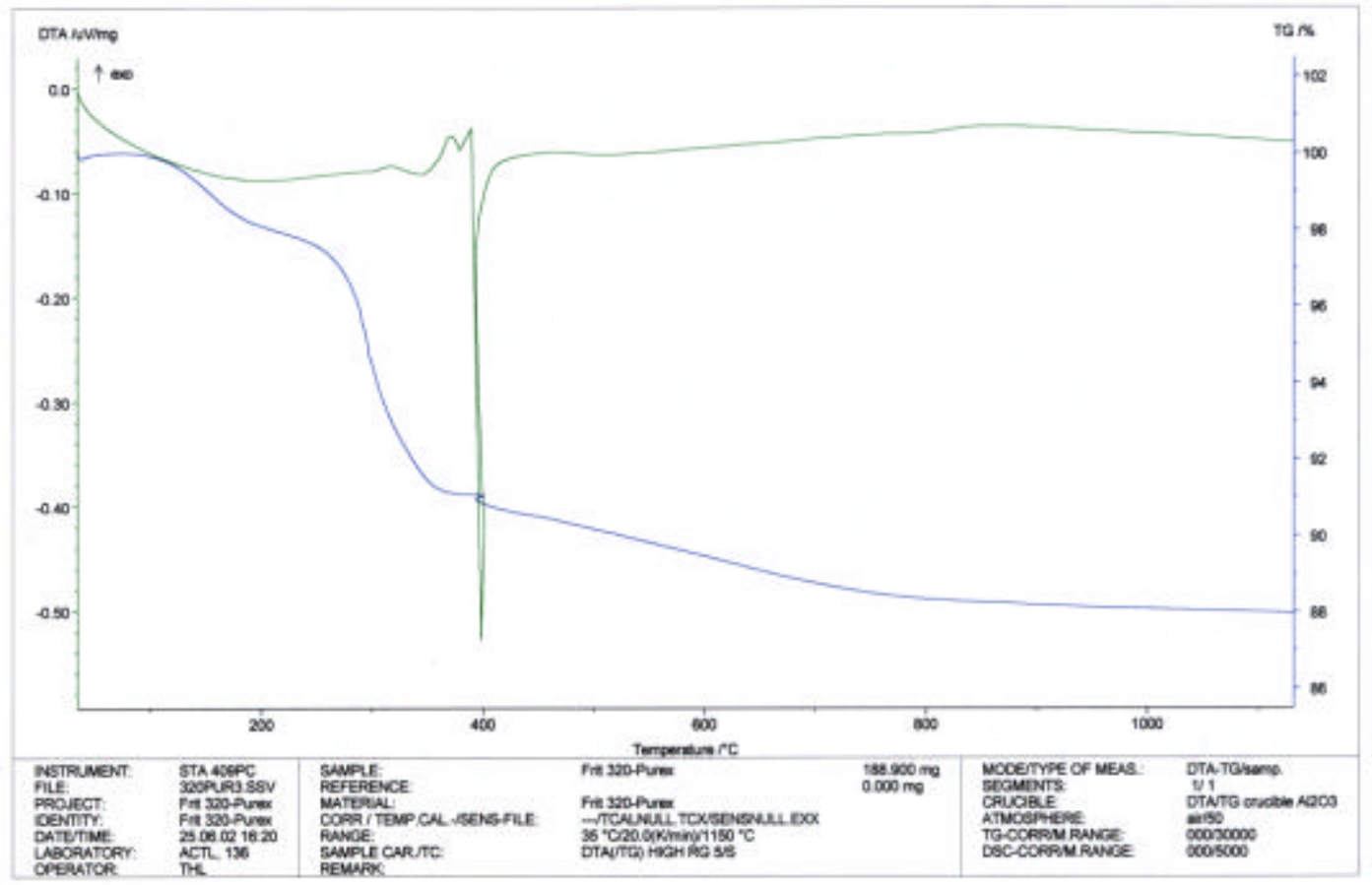

Frit $320+S B 2$

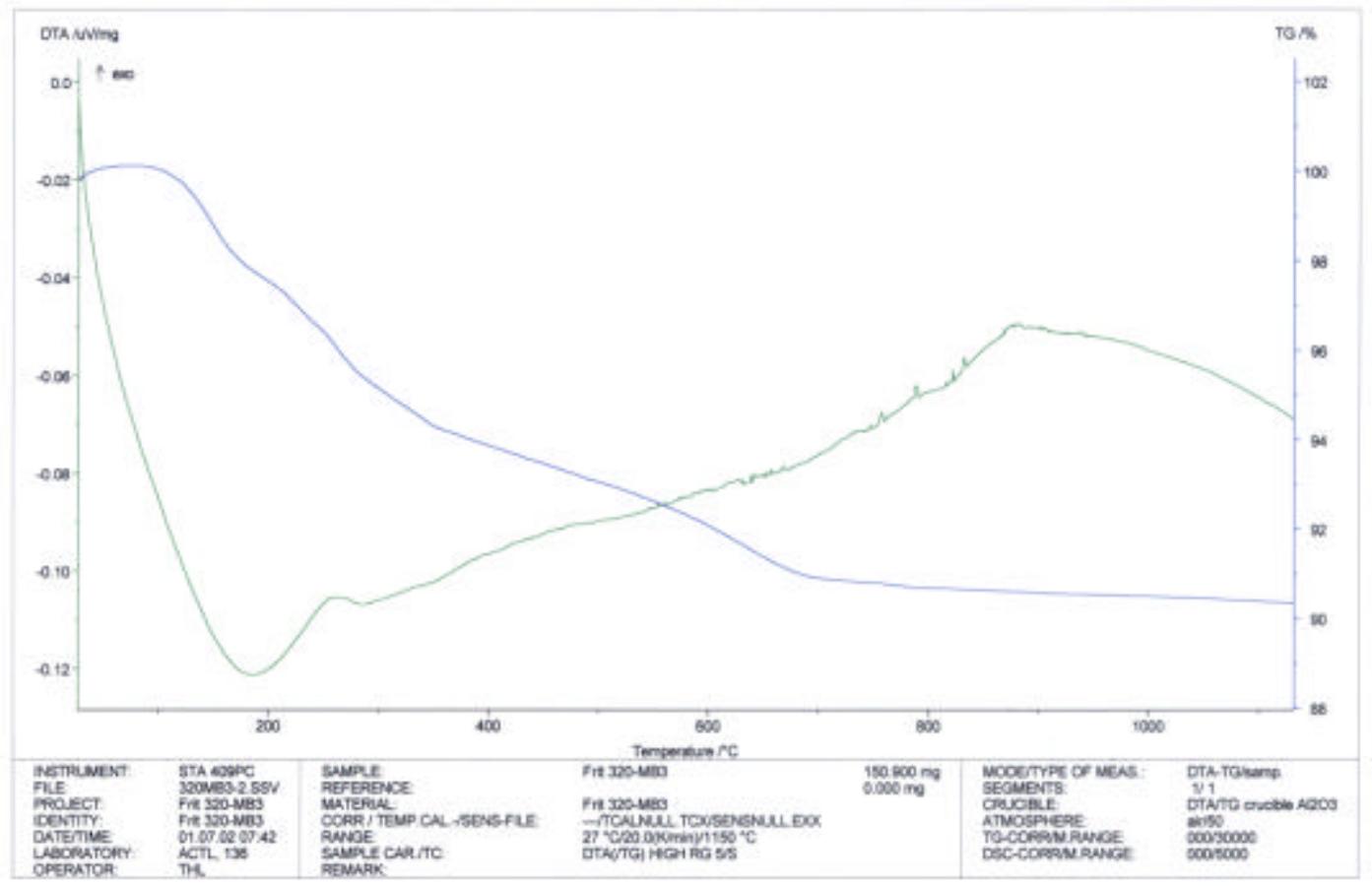


Immobilization Technology Section

Savannah River Technology Center

Westinghouse Savannah River Company

C2. Thermal Analysis Plots for the Higher Waste Loading Tests in the MRF

$27 \% W L$

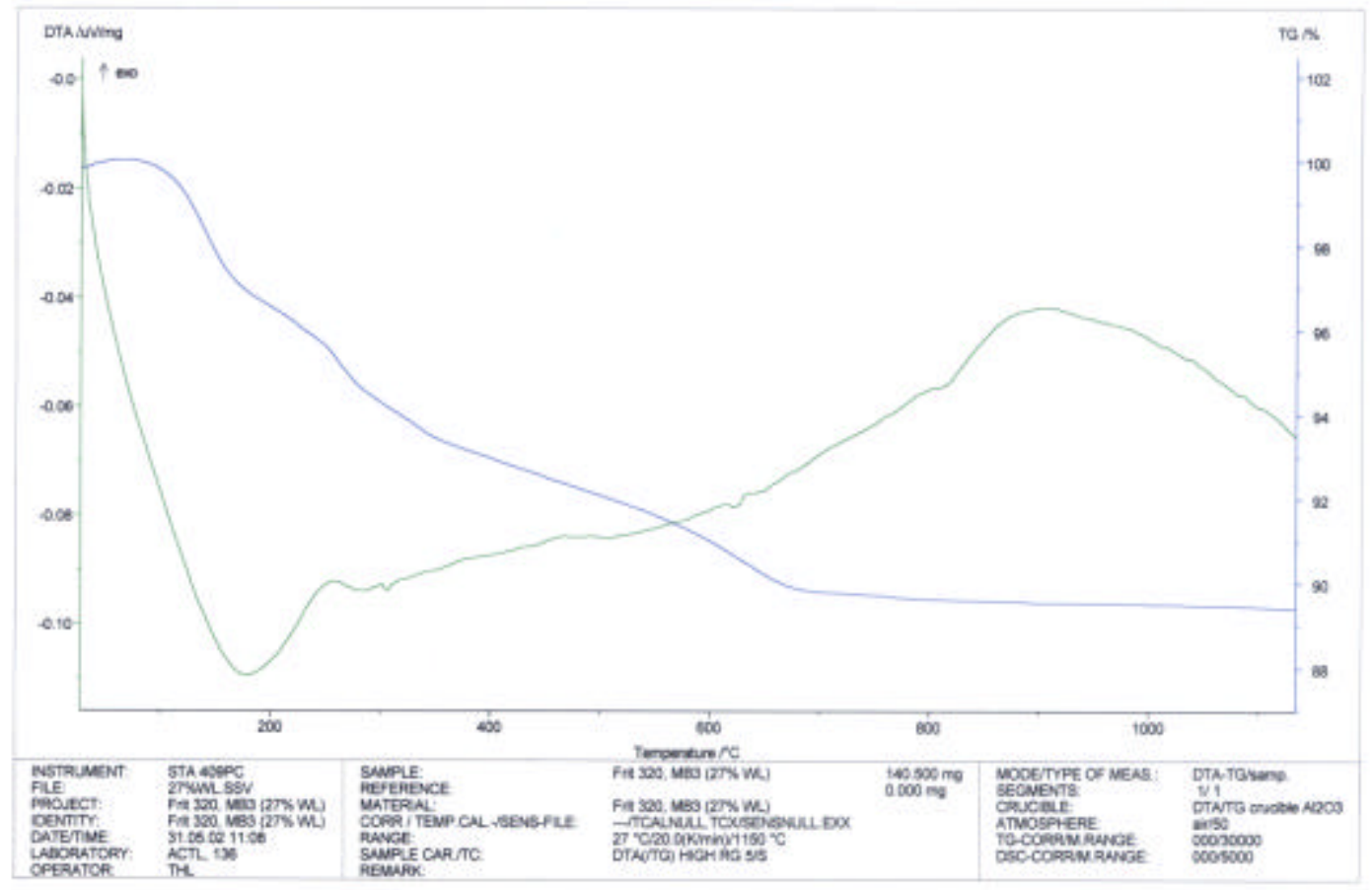

$29 \% W L$

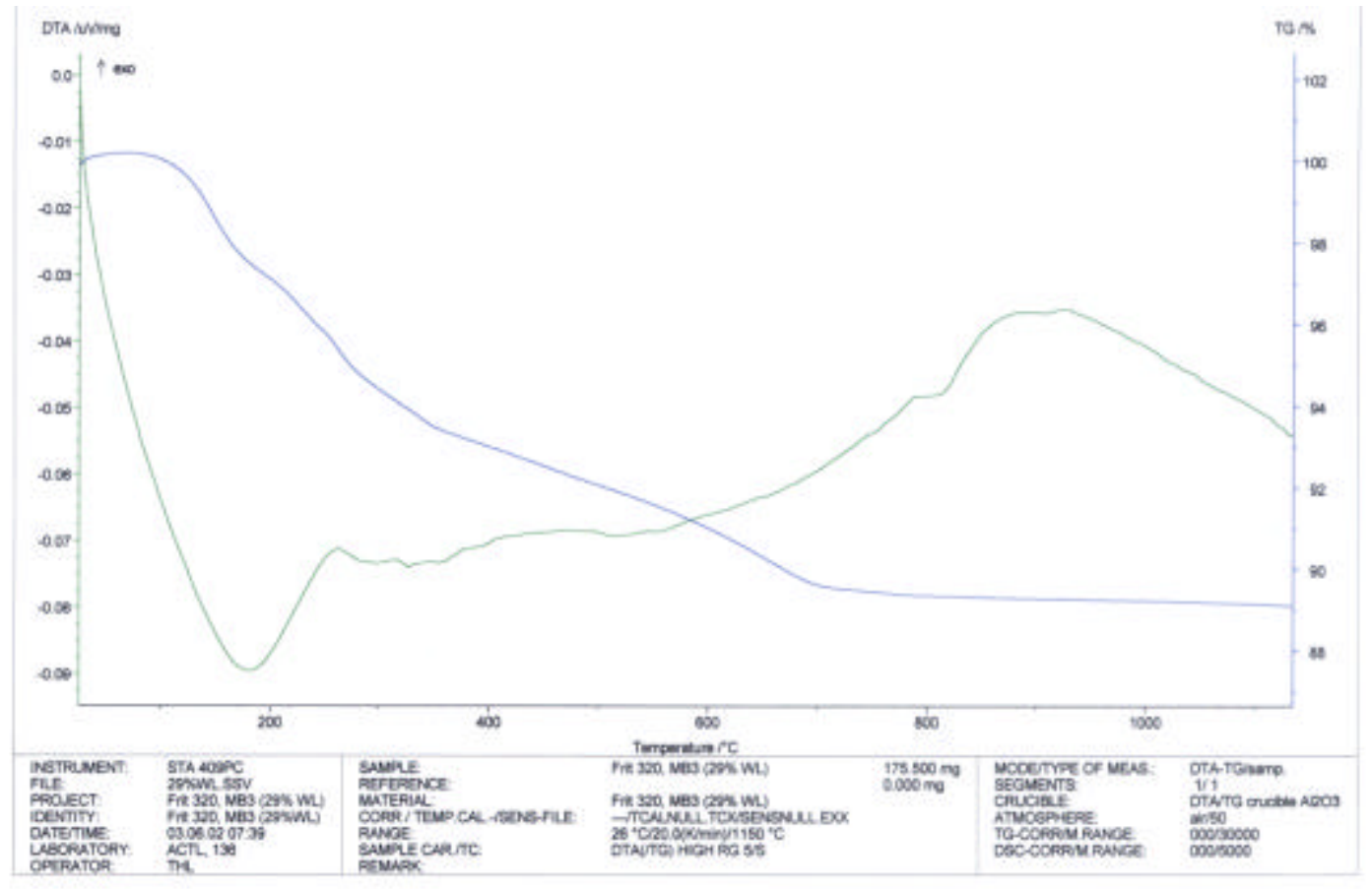


Immobilization Technology Section

Savannah River Technology Center

Westinghouse Savannah River Company

C2. (cont'd)

$31 \% W L$

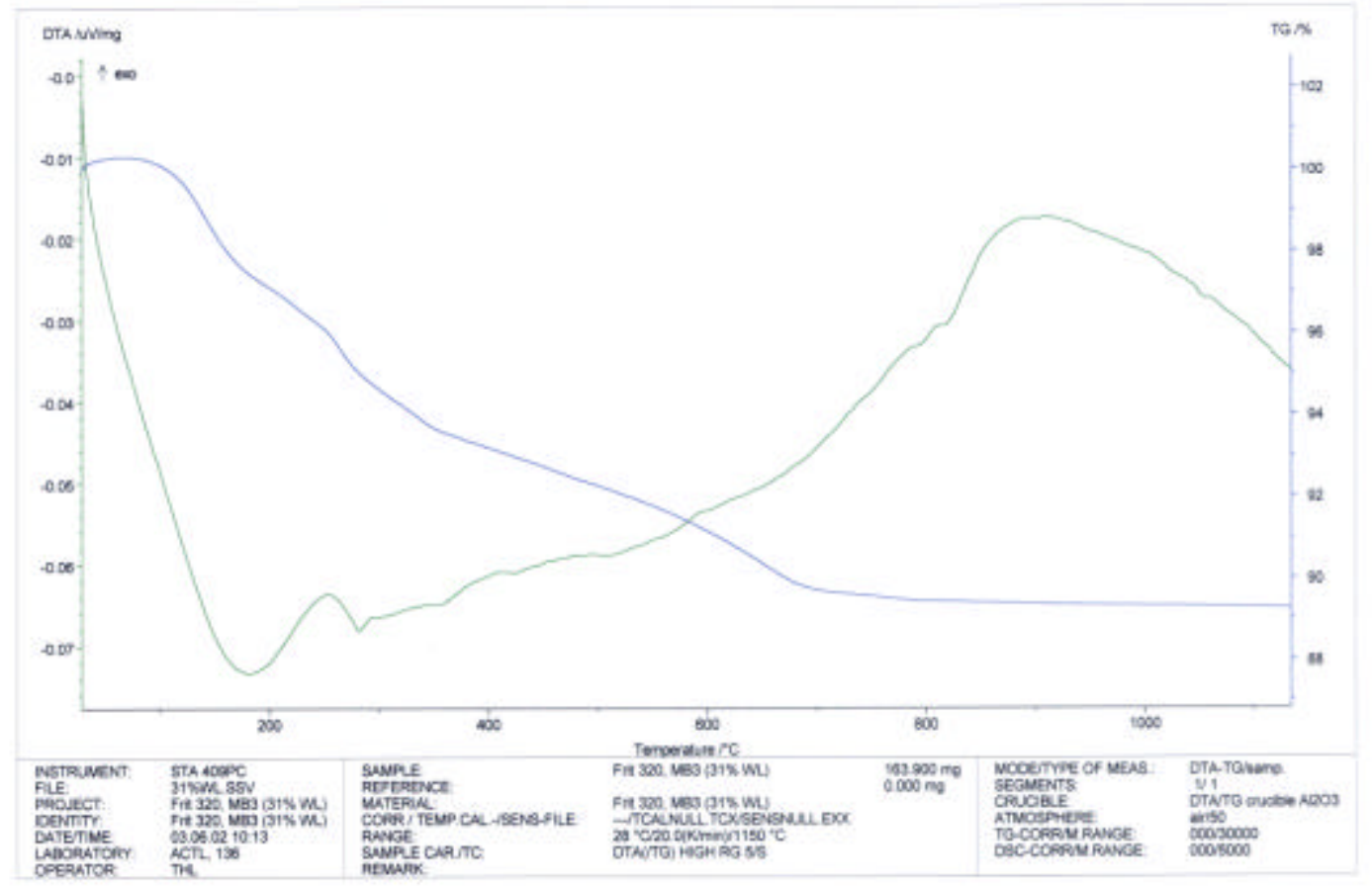

$33 \% W L$

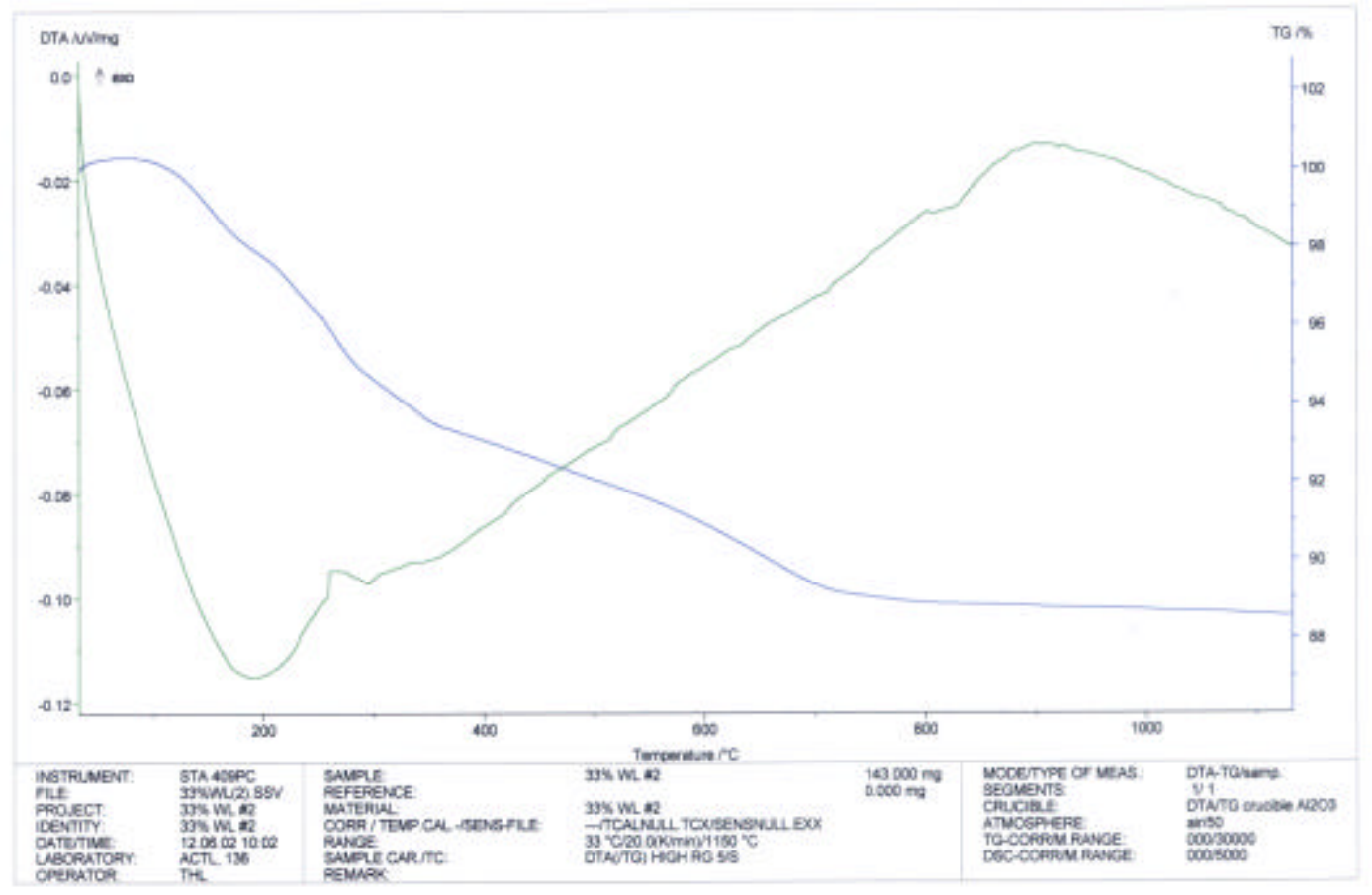


Immobilization Technology Section

Savannah River Technology Center

Westinghouse Savannah River Company

C2. (cont'd)

$35 \% W L$

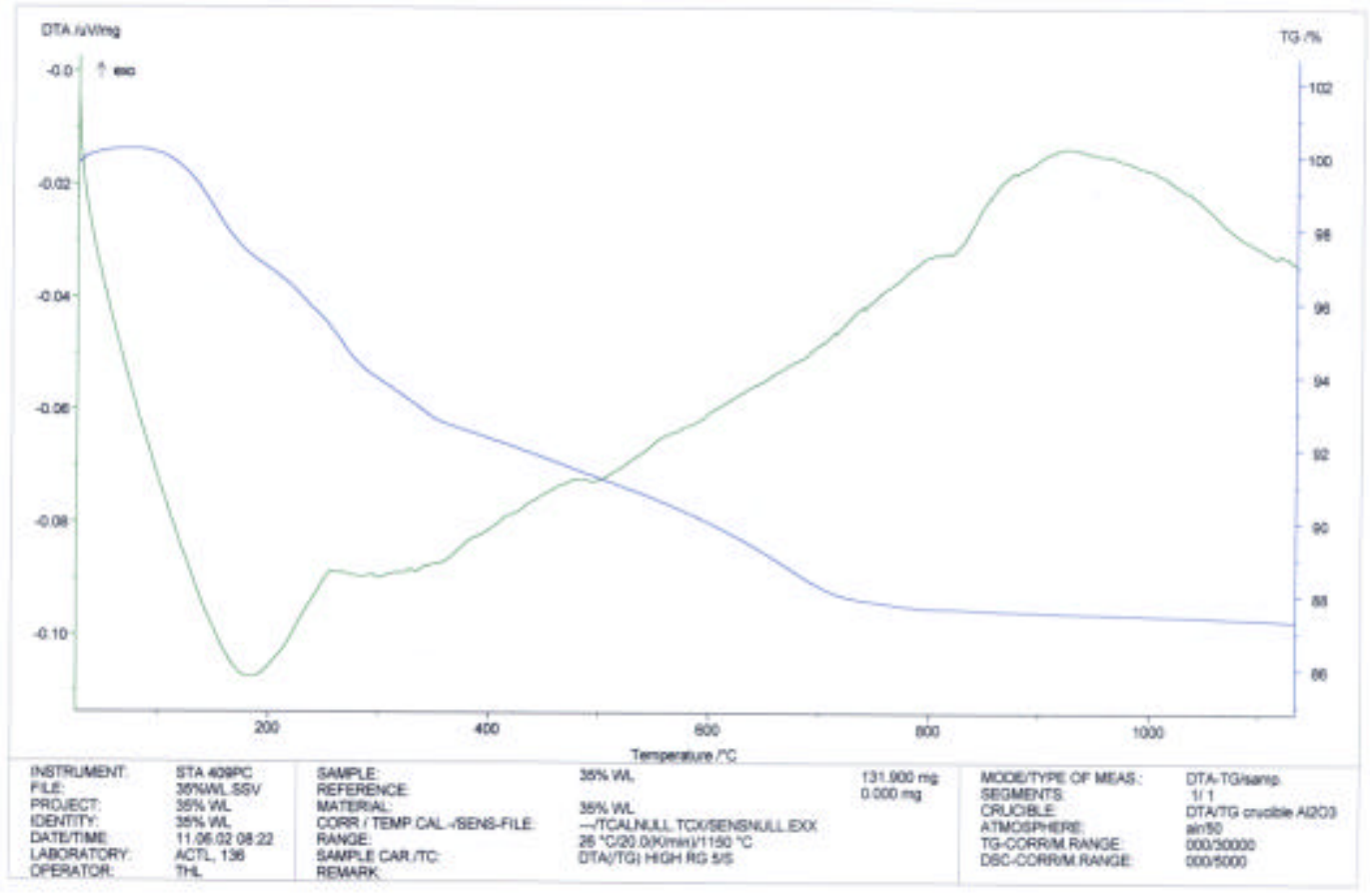

$37 \% W L$

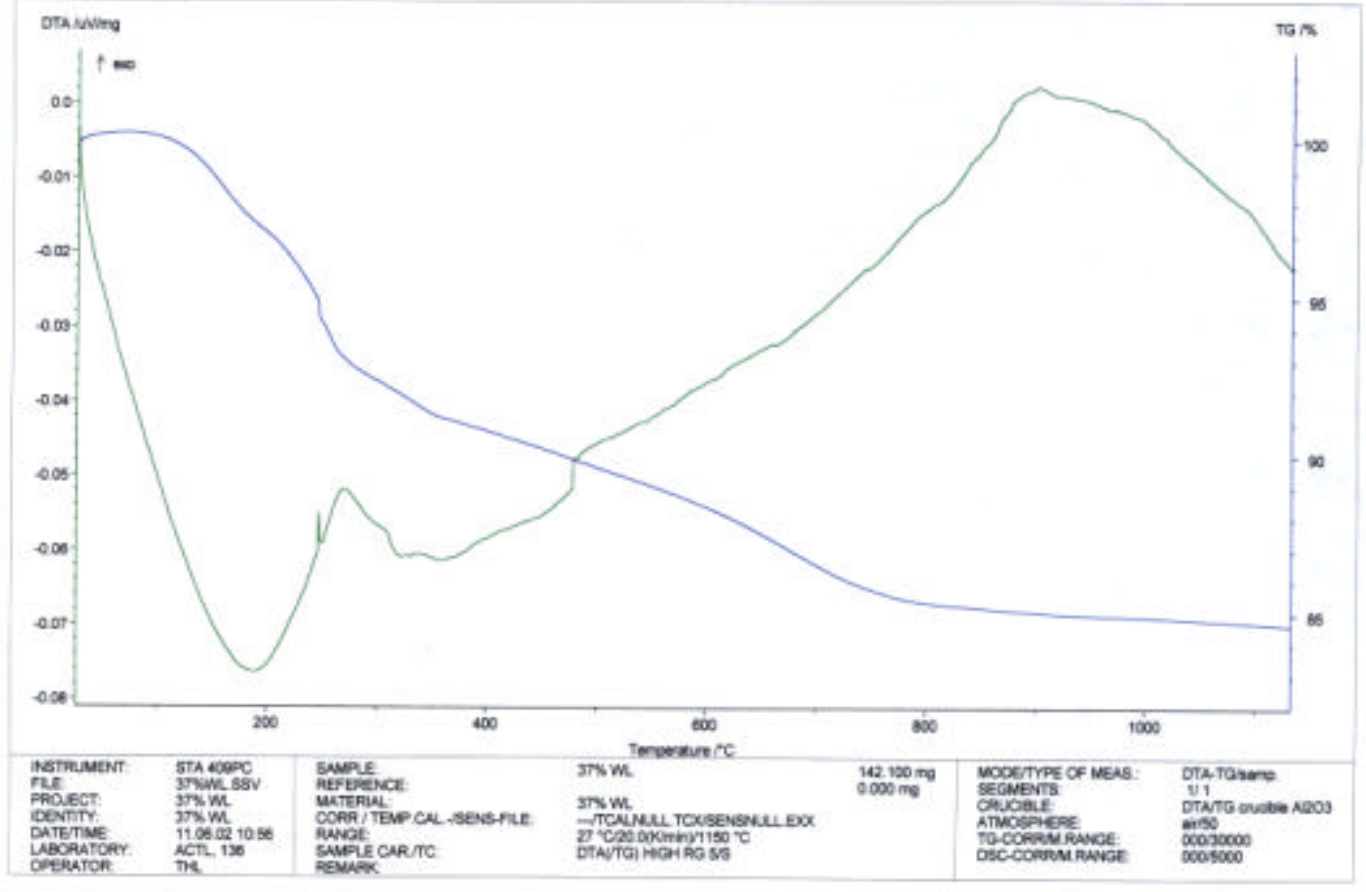


Immobilization Technology Section

Savannah River Technology Center

Westinghouse Savannah River Company

C2. (cont'd)

$38 \% W L$

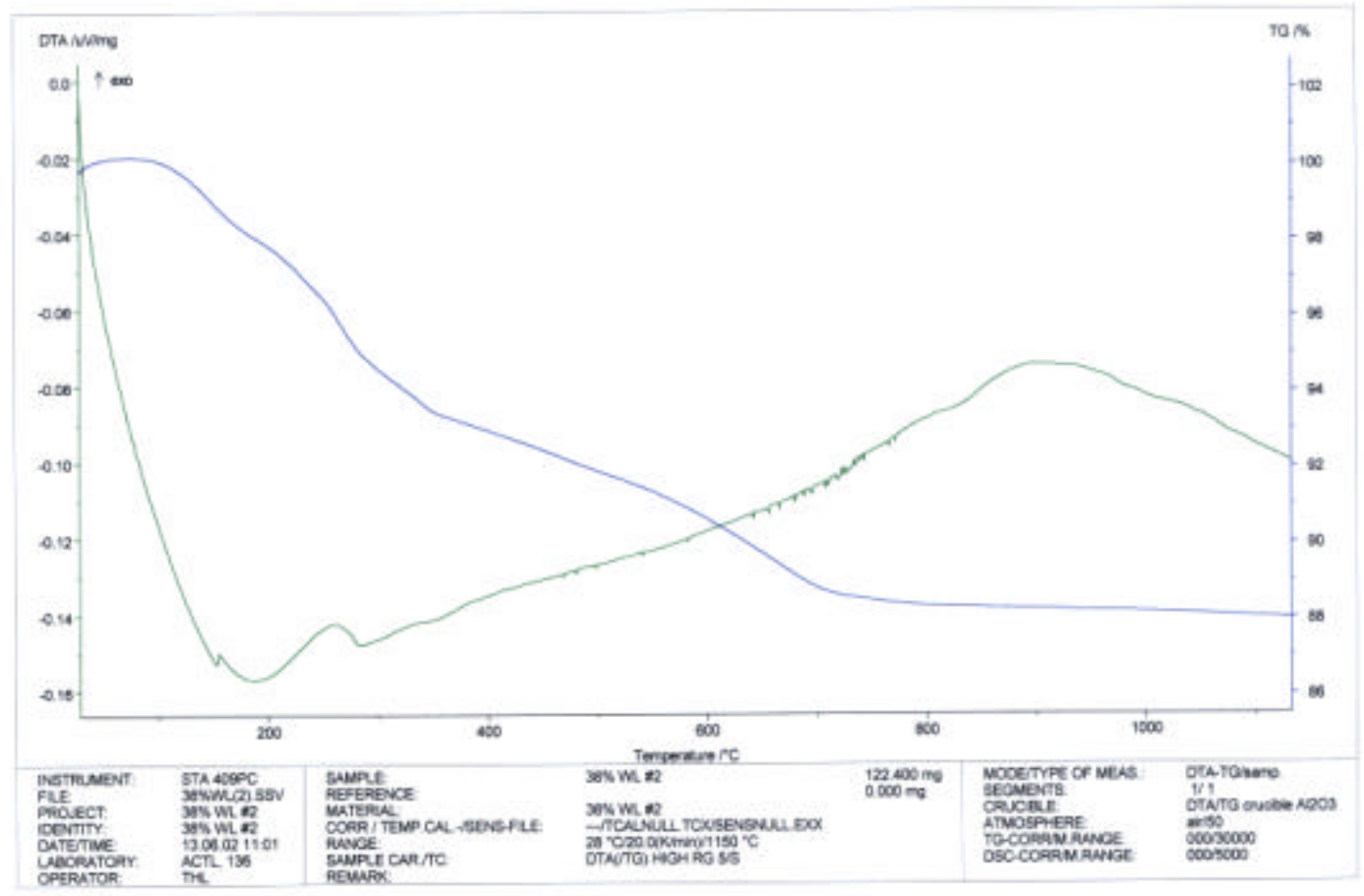

$39 \% W L$

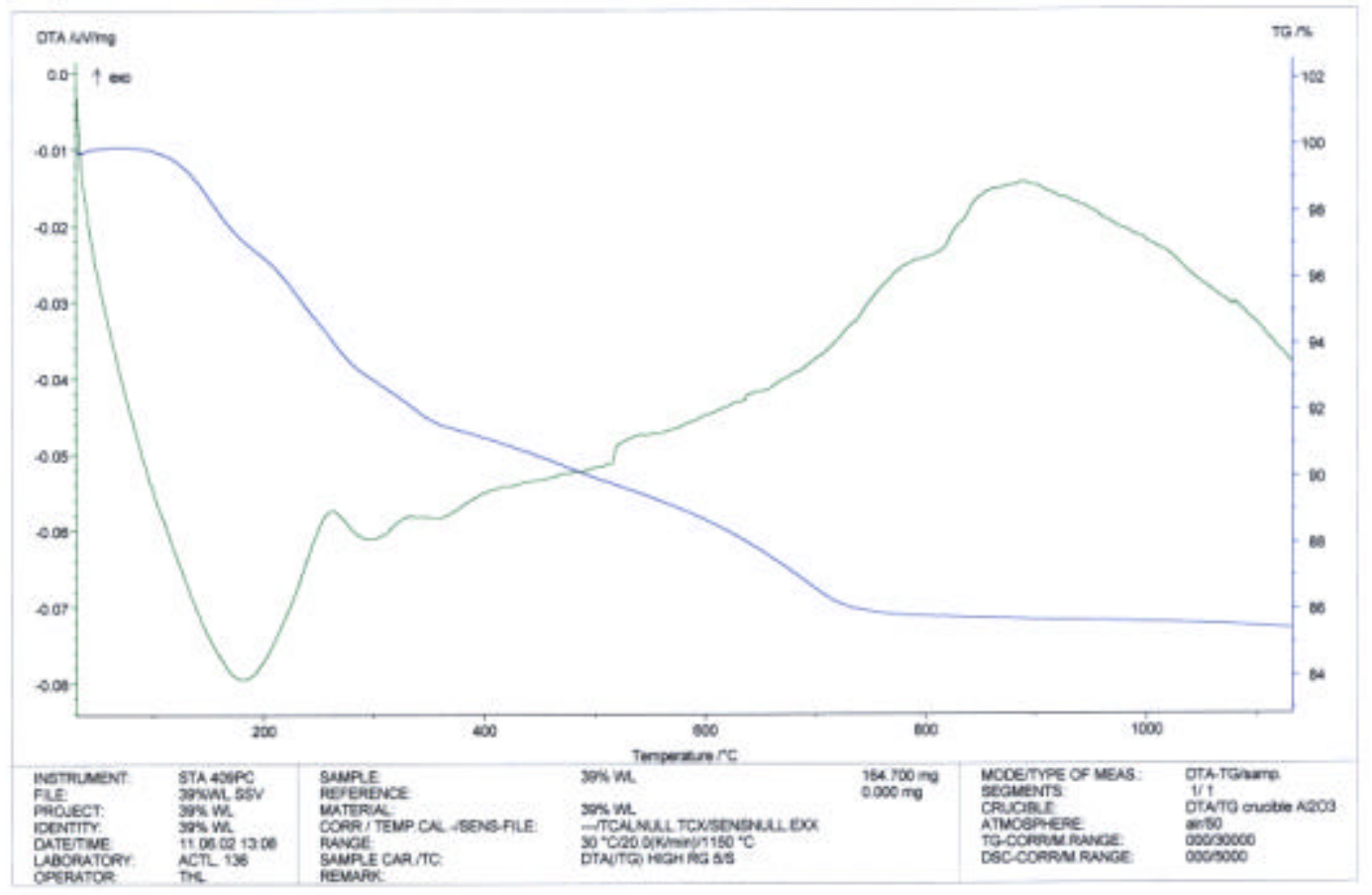


Immobilization Technology Section

Savannah River Technology Center

Westinghouse Savannah River Company

C2. (cont'd)

$41 \% W L$

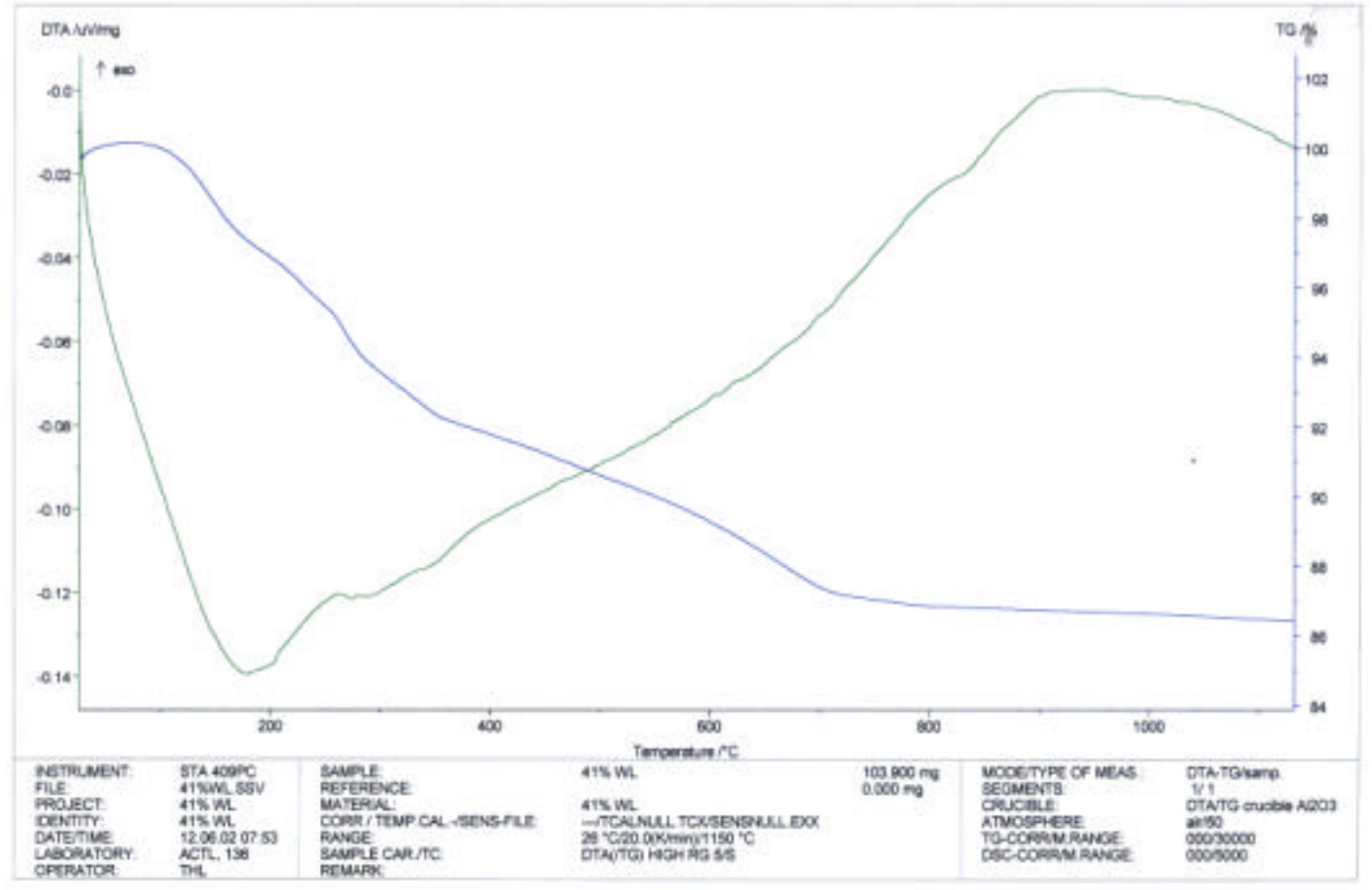


Immobilization Technology Section

Savannah River Technology Center

Westinghouse Savannah River Company

C3. Thermal Analysis Plots for the Frit Particle-size Tests in the MRF

Frit 320 Overs

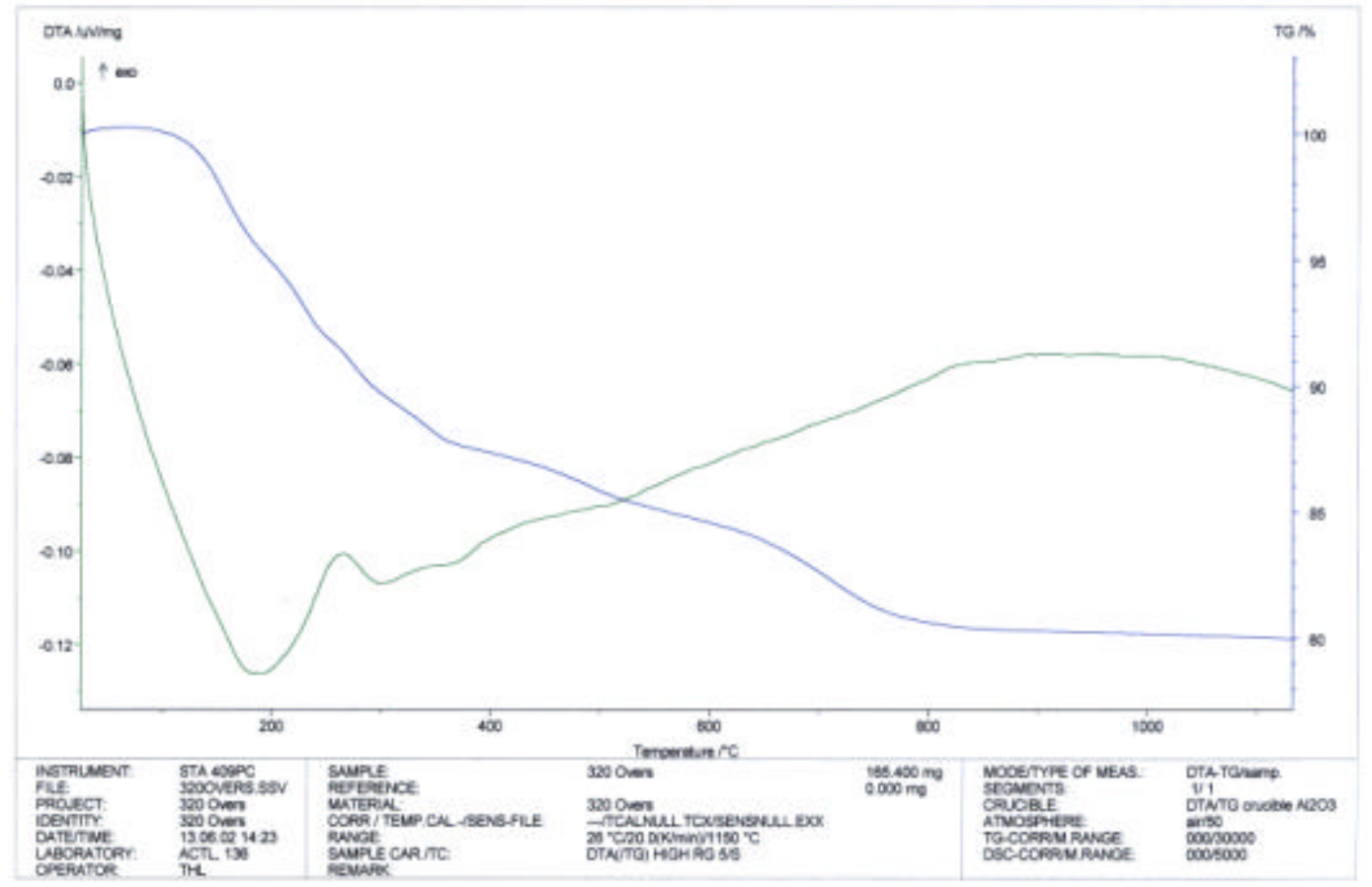

Frit 320 Unders

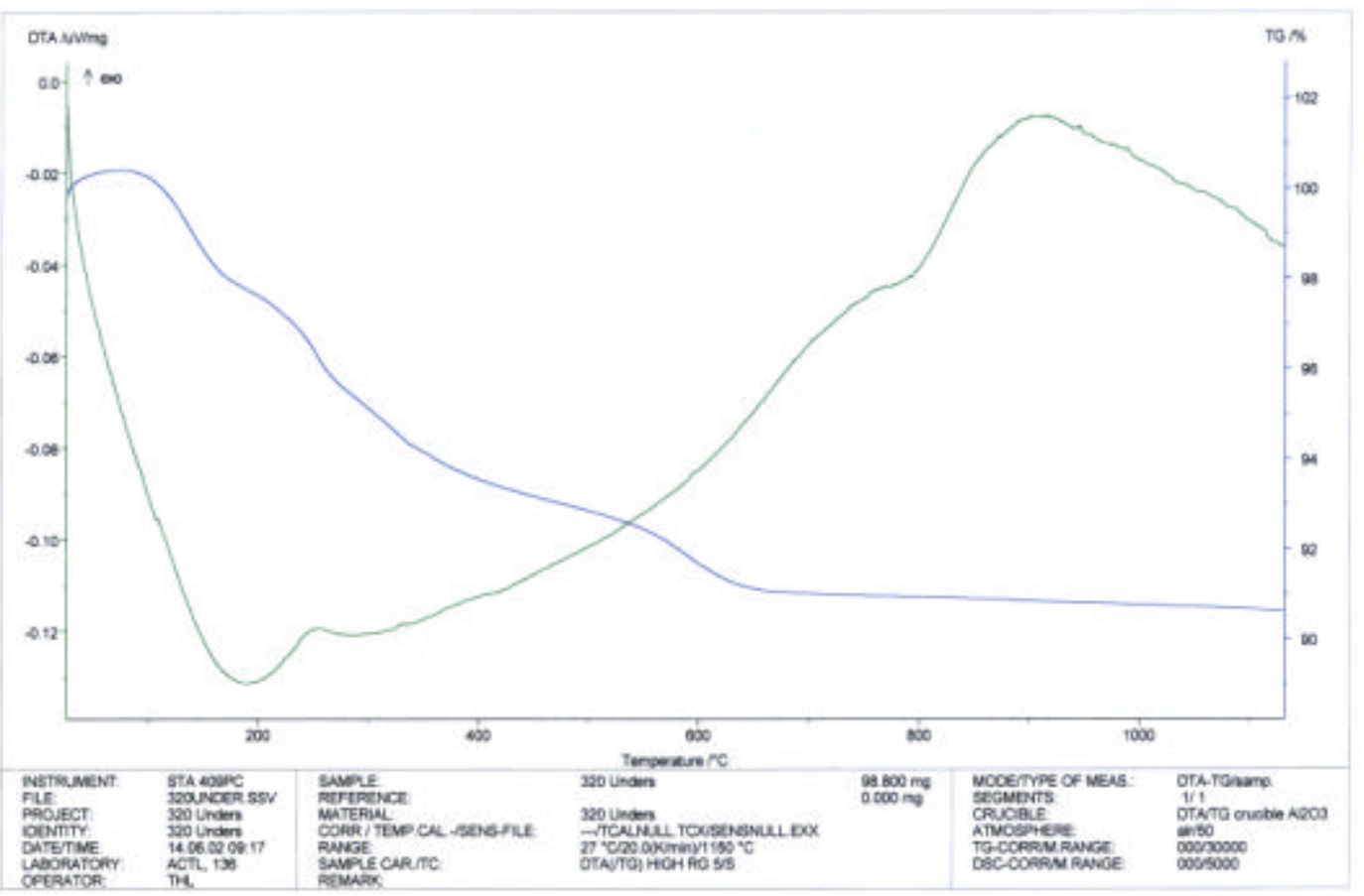

